\title{
DRONE-BASED ASSESSMENTS \\ OF CROWNS, CANOPY COVER AND \\ LAND USE TYPES IN AND AROUND \\ AN OIL PALM AGROFORESTRY EXPERIMENT
}

\author{
Dissertation \\ to attain the degree Doctor of Philosophy (Ph. D.) \\ of the Faculty of Forest Sciences and Forest Ecology \\ Georg-August-Universität Göttingen
}

\author{
Submitted by \\ Watit Khokthong \\ Born in Phitsanulok, Thailand
}

Göttingen, 2019 


\section{Reviewers}

Prof. Dr. Dirk Hölscher

Prof. Dr. Holger Kreft

Date of the oral examination: March 6, 2019 


\begin{abstract}
Oil palm cultivation has vastly expanded in the last decades and led to high economic returns, but has also induced environmental problems including reduced biological diversity and impaired ecosystem services. One potential way of reconciling economic and ecological needs would be to foster oil-palm agroforests by planting native tree species with the objective to enhance biodiversity and ecosystem services. In Sumatra, Indonesia, such an oil palm agroforestry experiment was established and a series of studies evaluated tree performance, oil palm yields and biodiversity changes. In this context, spatial information was relevant as the survival of planted trees may be influenced by neighborhood or the occurrence of specific taxa in experimental treatments may be influenced by the distance of source habitats. Drone-based assessments offer opportunities to support such spatial-structure related ecological studies. In this study, I used low and high flying drones (1) to analyze crown metrics of trees and palms to predict plant water use, (2) to study canopy cover in oil palm agroforest and the effect of oil palm canopy cover on tree mortality, and (3) to assess land use types surrounding the experiment. Objectives 1 and 2 were addressed with an octocopter drone, flying approximately $40 \mathrm{~m}$ above ground; while objective 3 was addressed by a fixed-wing drone, flying approximately $300 \mathrm{~m}$ above ground.
\end{abstract}

For study objective 1, I collaborated with a colleague who measured the water-use rates of individual trees and palms within the agroforestry experiment. Transpiration is often estimated from direct water-use measurements in a limited number of plants and then scaled up to the stand-level by using plant size related variables for the remaining plants. Presently, drone-based methods offer new opportunities for plant size assessments. We tested crown variables, derived from drone-based photogrammetry, for predicting and scaling plant water use. Aerial images were taken from an octocopter equipped with an RGB camera and the structure-from-motion approach was used to compute several crown variables including crown length, width and volume. Crown volumes for both palms (69\%) and trees $(81 \%)$ explained much of the observed spatial variability in water use; however, the specific crown volume model differed between palms and trees and there was no single linear model that fit both. With respect to trees, crown volume explained more of the observed variability than stem diameter, and in consequence, uncertainties in stand level estimates resulting from scaling were largely reduced. For oil palms, an appropriate whole-plant size related predictor variable was currently not available. In conclusion, we consider drone-derived crown metrics very useful for scaling up to stand-level transpiration from single plant water use.

For study objective 2, using a drone-based analysis, we compared oil palm canopy conditions in thinned and non-thinned plots and also examined how oil palm canopy cover affected the mortality rates of planted tree species. Three years after planting, canopy cover was assessed by drone-based photogrammetry using the structure-frommotion technique. Additionally, these surveys were augmented with tree positions and mortality rates recorded by colleagues. Drone-derived canopy cover was highly 
correlated with ground-based hemispheric photography along the equality line, indicating the usefulness and comparability of the approach. Canopy cover was further partitioned between oil palm and tree canopies. Oil palm canopy cover was then extracted at the level of individual trees and combined with ground-based mortality assessment for all 3819 planted trees. For three tree species (Archidendron pauciflorum, Durio zibethinus, Shorea leprosula), probability of mortality during the year of the study were dependent on the amount of oil palm canopy cover. Thinning of oil palms before tree planting created a more open and heterogeneous canopy cover. We regard the drone-based method for deriving and partitioning spatially explicit information as promising for many questions addressing canopy cover and the management of agroforestry systems.

For study objective 3, I assessed land use types in the landscape surrounding the oil palm agroforestry experiment. In two consecutive years, 2015 and 2016, 1121 ha were analyzed where the experiment is in the center. Beginning in 2015, oil palm covered $81 \%$ of the area and the remaining $19 \%$ comprised other land use types including bare soil, rubber plantation, secondary forest, orchard, fallow, water and urban. During this time frame, the area under oil palm continued to expand. In just one year, $50 \%$ of bare soil (47 ha), $27 \%$ of fallow (10 ha), $18 \%$ of secondary forest (10 ha) and $15 \%$ of rubber plantation (3.2 ha) were converted to oil palm plantation. We found oil palm cultivation in large and continuous tracts with very little fragmentation. Secondary forests were found in relatively small patches, some of which occurred in close proximity to the northern plots of the agroforestry experiment, and possibly influenced the occurrence of some mobile taxa. We conclude that it was feasible to derive detailed land cover maps from drone-based assessments that enable the detection of even small-scale land use change in the oil palm landscape.

Overall, drone-based assessments can play vital roles for ecological studies in oil palm landscapes and agroforests. The data from the photogrammetric approach, such as SfM point clouds and aerial imagery, can derive quality assessments of canopy structures. Specifically, such assessments can support the prediction of tree and oil palm water use, transpiration at the stand level, and the evaluation of oil palm canopy conditions between thinned and non-thinned plots. According to these drone-based assessments, oil palm canopy cover appeared to influence the mortality of some tree species in the oil palm agroforestry plots. In addition, drone-based monitoring could be used to detect the expansion of oil palm cultivation around the oil palm agroforest. Other applied workflows in forestry and agricultural studies can integrate our procedures to attain spatial information. I conclude that drone-based assessment is a well-suited tool for monitoring oil-palm agroforests, in both small scale and large areas. 


\section{Table of Contents}

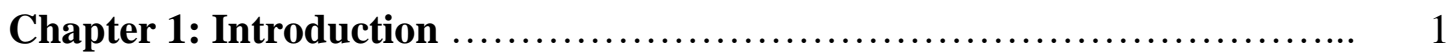

1.1 Oil palm agroforest.................................................. 1

1.2 Drone application in oil palm agroforest.................................. 1

1.3 Tree crown and canopy structure derivation from drone..................... 2

1.4 Canopy cover assessment from drone and relevant methods from ground-based estimation.................................................. 2

1.5 Monitoring oil palm dominated landscape with drone.................... 4

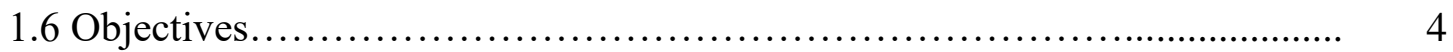

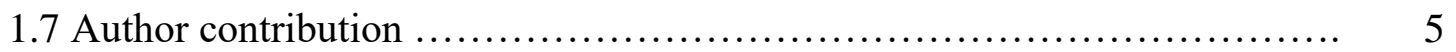

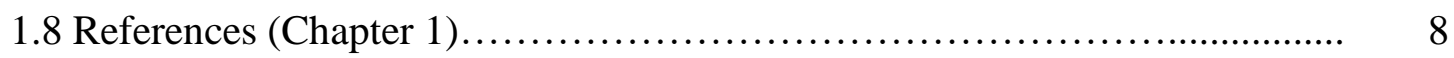

Chapter 2: Drone-based photogrammetry derived crown metrics for predicting tree and oil palm water use ................................................ 13

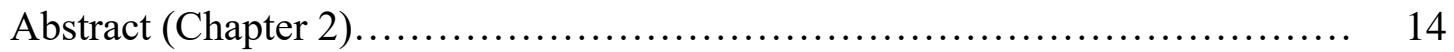

2.1 Introduction............................................................. 15

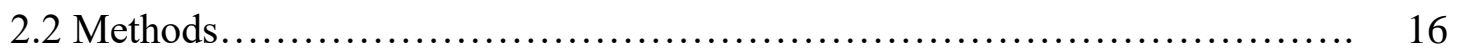

2.3 Results........................................................ 22

2.4 Discussion......................................................... 26

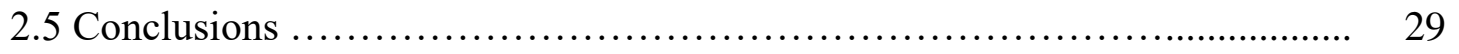

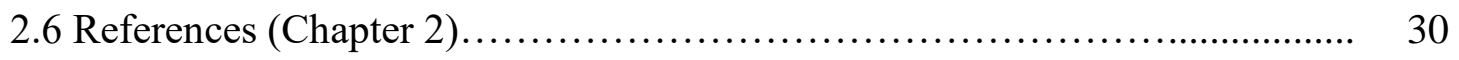

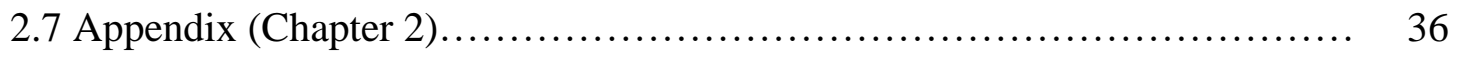

2.8 A full methodology description of drone image acquisition and crown metric processing (Chapter 2) ........................................... 44 
Chapter 3: Drone-based assessment of canopy cover

for analyzing tree mortality in an oil palm agroforest..................... 49

Abstract (Chapter 3) ............................................. 50

3.1 Introduction......................................................... 51

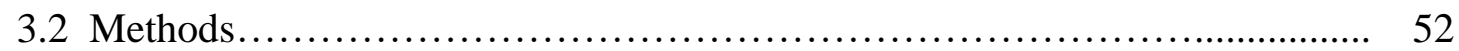

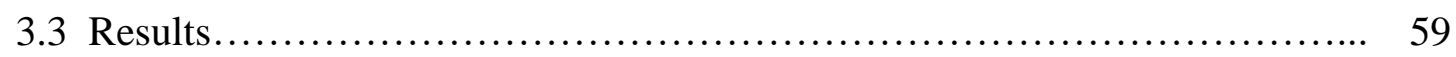

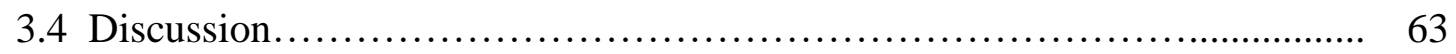

3.5 Conclusions..................................................... 64

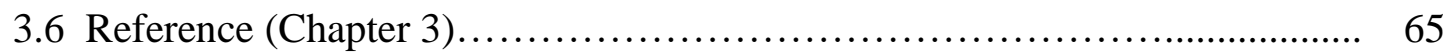

3.7 Appendix $($ Chapter 3) .......................................... 71

Chapter 4: Land use and its short-term changes around the oil palm agroforestry experiment......................................................... 79

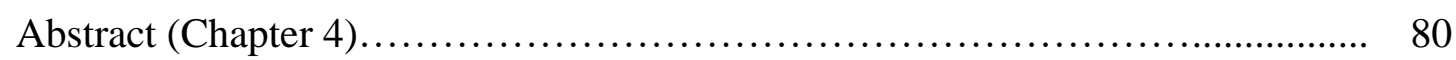

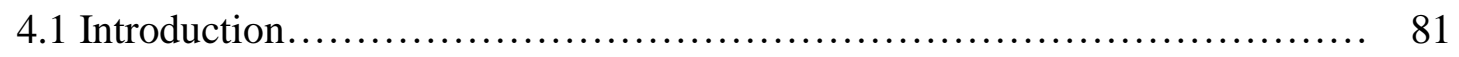

4.2 Methods..................................................................... 81

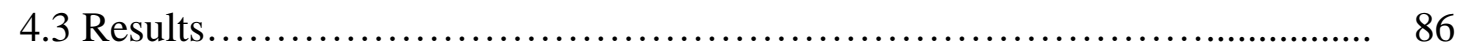

4.4 Discussion..................................................... 90

4.5 Conclusions .................................................... 92

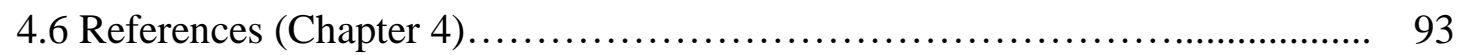

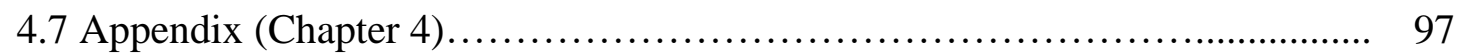

Chapter 5: Synthesis............................................. 107

5.1 Usefulness of drone-based data for crown metrics and canopy cover analyses...................................................... 107

5.2 Success of using drone-based variables in oil palm agroforestry experiments 
5.3 Landscape context analysis with spatial data from fixed-wing drone. 108

5.4 Disadvantage of fixed-wing drone and limitation of methods....................... 109

5.5 Future outlook......................................................... 109

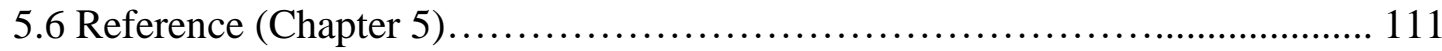

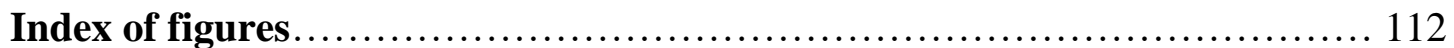

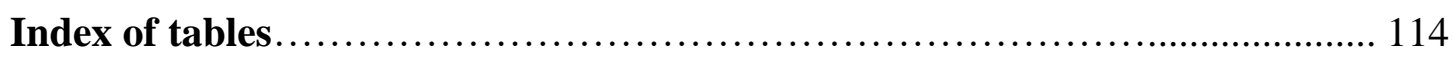

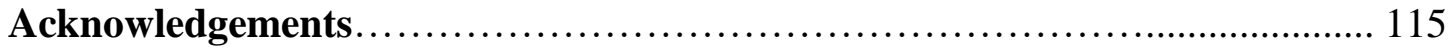

Declaration of honor....................................................... 116

Curriculum vitae.......................................................... 117 



\section{Chapter 1}

\section{Introduction}

\subsection{Oil palm agroforest}

Oil palm (Elaeis guineensis) cultivation has been rapidly expanding over the past decades (FAO 2016). A particular area of expansion is Indonesia, where oil palm cultivation usually appears in monocultures (Abood et al. 2015) and is related to forest degradation (Koh and Wilcove 2008). Previously, there were concerns in oil palm plantation with focuses on environmental issue (Fitzherbert et al. 2008). The effects of rapid of oil palm expansion potentially caused widespread biodiversity loss (Koh and Wilcove 2008; Foster et al. 2011). Additionally, ecosystem functions were poor in oil palm plantations compared to the forests that formerly covered these areas (Dislich et al. 2017). So far, there are difficulties in policy planning to sustain biodiversity in oil palm monocultures (Padfield et al. 2016). In this way, planting other trees within plantations to create oil-palm agroforestry systems is one option for biodiversity enrichment (Teuscher et al. 2016).

\subsection{Drone application in oil palm agroforest}

Drones have been introduced as a remote sensing platform that can capture aerial imagery and valuable information from other sensors including light detection ranging (LiDAR), and cameras in multispectral bands (Tang and Shao 2015). The flexibility and advantages of drone application have caused the number of surveys in agricultural and forests areas to increase (Pádua et al. 2017). Focusing on oil palm plantations, there are many aspects of the rise drone technology that help to promote more sustainable oil palm plantations and establish a well-managed oil palm industry (Chong et al. 2017). On the other hand, many studies conducted in oil palm plantations have included wellestablished methods using satellite imagery (Srestasathiern and Rakwatin 2014; Santoso et al. 2016; Santos et al. 2017). Drone-based surveys were originally invented for agricultural purposes and precision measurements, but are very promising for oilpalm landscape monitoring and management (Sari et al. 2017; Tugi et al. 2015). However, the drone application in agroforest monitoring and management is not yet practical because of the lack of studies in specific research area.

Drone application is a useful remote sensing tool for ecological monitoring in oil palm agroforestry. Pádua et al. (2017) reviewed the common aspects of using drones in agriculture and forestry settings and reported that drones are applicable in agroforestry systems; however, efficacy of drone applications and some of the limitations should be considered. Nevertheless, drones were recommended to be implemented in agroforestry areas for post-fire burn assessment, wildlife detection, and vegetation height maps (Pádua et al. 2017). Until now, there have been relatively few developments towards a sustainable approach in oil palm agroforestry (Wicke et al. 2011) and studies with 
drone-based monitoring for such systems are rarely found. In order to use drones to extract ecologically relevant information from oil-palm agroforests, the drone-related dataset should be first related to established method and validation parameters from ground-based measurements.

\subsection{Tree crown and canopy structure derivation from drone}

The measurements of tree crown structure usually involves vertical and horizontal views of canopy and there are many variables that can be evaluated from ground-based techniques (Pretzsch et al. 2015). Alternatively, vertical height of oil palms can be measured directly from canopy height model (CHM) (Nunes et al. 2017). After integrating horizontal parameters of single tree canopies to create a crown projection of forest stand, a canopy map is generated (Lang and Kurvits 2007) and used for canopy cover estimation (Avsar and Ayyildiz 2010). Previously, Zhang et al. (1999) measured transpiration rate for single of poplar trees (Populus spp.) per unit of crown projected area. Therefore, I regard drone derivation of individual tree and oil palm canopy structures as a supportive tool in the study of tree water use. However, the focus of water use prediction in relation to crown and canopy structure has not yet been investigated with drone methods.

Cameras are an essential part of drone-equipped sensors and have been widely used for the measurement the tree canopy attributes (Chianucci et al. 2016; Birdal et al. 2017). Likewise, light weight LiDAR devices are also possible to install on drones (Lin et al. 2011). The point clouds from both LiDAR and SfM enable algorithms for individual tree delineation, tree height estimation and crown structure determination (Lim et al. 2015; Kallimani 2016; Trochta et al. 2017). Moreover, integration of the SfM point clouds to follow with well-established LiDAR workflows is very promising (Balcomb 2015; Wallace et al. 2016). As a result, the high density point clouds produced highly accurate crown structures and characteristics, such as parameters of crown length, crown diameter, crown surface curvature (Kallimani 2016) and canopy density (Jensen and Mathews 2016). However, the drone-derived point clouds lack penetration in very dense tree canopies (Mohan et al. 2017). Consequently, the capacity of drone use for crown structure measurement should be validated with field measurements in order to contribute other biological-physical attributes.

\subsection{Canopy cover assessment from drone and relevant methods from ground- based estimation}

Forest canopy cover is defined as the proportion of the forest floor covered by the vertical projection of the tree crowns (Jennings et al. 1999). To measure canopy cover, the method usually includes the small gaps between leaves in the calculation, but excludes dead branches of tree (Jennings et al. 1999). In general, canopy cover is slightly different to canopy closure, the latter of which refers to a measured projection, with defined view angles, from a single point of view (Korhonen et al. 2006). The value from canopy cover can be directly converted to the gap fraction and canopy openness 
(Tichý 2016) which are commonly used in the study of microhabitat environments within the forest stands (Nilson and Peterson 1991).

There is an increasing trend to use light weight drones as a platform to attach an array of cameras and sensors (Dandois and Ellis 2013; Anderson and Gaston 2013). The aerial imagery from drones has emerged as a technique in the estimation of forest canopy cover with RGB images (Chianucci et al. 2016; Banu et al. 2017) and multispectral imagery (Shin et al. 2018). On the other hand, the three dimensional (3D) point clouds have been involved in canopy closure estimation (Zhang et al. 2016). In parallel, the SfM point clouds could also produce canopy cover map (Wallace et al. 2016). However, the accuracy of canopy cover estimated from SfM point clouds might be poor in dense canopy conditions because the SfM technique could not reach the ground surface and canopy cover calculations require the terrain point clouds (Tomaštík et al. 2017). Furthermore, advanced satellite imagery has also been involved in tree canopy estimations. For example, the canopy closure was estimated from Ikonos satellite imagery (Chubey et al. 2006), and the canopy cover from a high resolution QuickBird $(0.6 \mathrm{~m})$ and panchromatic satellite imagery have been validated with field monitoring (Chopping 2011).

So far, many traditional forest inventories have been focused on canopy cover estimation with ground-based tools. Utilizing photographs from indirect optical methods have been involved with canopy cover estimation, for example hemispherical photography using a fish-eye lens (Leblanc and Fournier 2017) and canopy photography using a typical lens (Chianucci et al. 2014). The angles of view are commonly between $40^{\circ}$ and $60^{\circ}$, which are recommended for assessing canopy closer and gap fraction (Korhonen 2011; Weiss and Baret 2016; Leblanc and Fournier 2017). The high resolution photography can distinguish small gaps in the canopy with the background of sky (Beckschäfer et al. 2013). Therefore, the algorithms for calculating vertical canopy cover with the hemispherical photograph and canopy photography are well established (Weiss and Baret 2016). The advantage of using these photographs is due to the nature of angular field of view sampling, especially for the fish-eye lens (Korhonen et al. 2006). However, some limitations of method were noted in heterogeneous stands and very large areas that usually require a high amount of post processing time (Korhonen et al. 2006; Leblanc and Fournier 2017).

Previously, the Canjanus sighting tube was the most suitable tool for measuring canopy cover at vertical projection; a simple cylinder mounted with a mirror for the user to look upward and determine the canopy cover within a top crosshair (Jennings et al. 1999; Korhonen et al. 2006). Another method is using tape measurement with the line intersect sampling (Korhonen 2011). Additionally, the crown relascope was used to measure crown width through a visual projection (Bitterlick 1984) and the spherical densitometer based on ocular estimation (Lemmon 1956) are both very feasible techniques to assess canopy cover from ground based measurements. Considering ground-based measurements, care should be taken when measuring because crown 
projection is non-circular and overlapping, and these aspects require measurements in several radii from a single tree and require much time in a large observation area (Korhonen 2011). Alternatively, one can use model predictions of canopy cover that have been integrated with some parameters of more easily measurable tree characteristics such as stand basal area (Mitchell and Popovich 1997; Vaughn and Ritchie 2005).

\subsection{Monitoring oil palm dominated landscape with drone}

Drone-based aerial monitoring, image processing and methods of land use classification can provide accurate land use maps and also estimate area of oil palm plantation (Kalantar et al. 2017). Indeed, drone application is affordable in scale- and time-independent surveys depending on the aspects of study (Puliti et al. 2015). Thus far, the focus of drones in oil palm plantations are usually based on techniques from precision farming (Sari et al. 2017) and productivity (Shamshiri 2018). For example, oil palm counting from drone imagery have been evaluated by an automatic algorithm (Li et al. 2017). Additionally, healthy oil palm canopies could be detected from drone imagery with spectral reflectance (Tugi et al. 2015). In the context of oil palm landscape monitoring, using drones to detect landscape changes over time is possible. However, this application may present challenges; for example, drones can only fly within a limited distance from the operator, and also need an adequate power supply for longdistance flying on a landscape scale (Puliti et al. 2015). In comparison to satellite datasets, analysis between regional and national scales from satellite imagery may present outputs that may not be compatible for analysis, such as different classes of land use and coarse spatial resolution. In this way, high resolution maps and accurate land use information from drone-based monitoring are important for filling data gaps of different data sources, qualities, and time frames. Moreover, accurate land use maps and high data quality are very helpful for land use policy development in oil palm dominated landscapes (Wicke et al. 2011).

\subsection{Objectives}

We conducted drone surveys with varying flight strategies in different scales of area, within and covering the biodiversity enrichment experiment (EFForTS-BEE) with a gap enrichment planting experiment in an oil palm plantation, which has been established since 2013 (Teuscher et al. 2016). Drone-based SfM point clouds were constructed from aerial image-matching following photogrammetric techniques (Westoby et al. 2012). The first two topics corresponded with utilizing 3D point clouds to generate crown metrics and canopy cover, which were further analyzed with available data of tree and oil palm water use, and tree mortality monitoring from filedbased operations. The third topic was in focus of drone for landscape imagery, and land use change analysis. In particular, the following research objectives are addressed: 
Objective 1: to test drone derived tree and oil palm crown variables for water use prediction from plant scale to stand-level transpiration and compare transpiration rates of an oil palm monoculture to an oil palm agroforest

Objective 2: to generate high resolution maps of canopy cover from drone-based point clouds and integrate canopy cover of oil palm with the analysis of tree species mortality

Objective 3: to evaluate land use change and extension area of oil palm plantation in and around area of oil-palm agroforestry experiment

\subsection{Author contribution}

The dissertation is substantiated by three manuscripts (Chapter 2-4) at different stages of the publication process (i.e. "Accepted manuscript", "In revision" and "Advanced manuscript"). The status as well as the contributions of the co-authors to each manuscript are indicated. All chapters in dissertation were mainly written by the author (referred to as "WK").

\section{Chapter 2: Drone-based photogrammetry derived crown metrics for predicting tree and oil palm water use}

Joyson Ahongshangbam*, Watit Khokthong*, Florian Ellsäßer, Hendrayanto, Dirk Hölscher, Alexander Röll

In revision at Ecohydrology

JA and WK equally contributed to the article (*). The experiment was designed by JA, WK and DH. WK conducted drone-based measurements and measured tree crown variables from ground-based measurements. JA and FA conducted the water use experiment with sap flux technique. The statistical portion was analyzed by JA and AR. The article was written by JA, WK, FA, AR and DH. In particular, WK wrote introduction and method sections and largely wrote a full drone methodology part in the chapter 2.8 . 
Chapter 3: Drone-based assessment of canopy cover for analyzing tree mortality in an oil palm agroforest

Watit Khokthong, Delphine Clara Zemp, Bambang Irawan, Leti Sundawati, Holger Kreft, Dirk Hölscher

Accepted manuscript in Frontiers in Forests and Global Change (2019). doi: $10.3389 /$ ffgc.2019.00012

Concepts of this study were conceived by DH, WK and DCZ. WK conducted dronederived canopy cover and filed experiment of hemispherical photographs. DCZ provided tree and oil palm from field monitoring data. WK conducted all the data analysis. WK, DCZ and DH wrote manuscript with comments and revision from HK. All authors contributed in the final approval for submission of the manuscript.

Chapter 4: Land use and its short-term changes around the oil palm agroforestry experiment

Watit Khokthong, Paul Magdon, Delphine Clara Zemp, Bambang Irawan, Leti Sundawati, Holger Kreft, Dirk Hölscher

Advanced manuscript

WK conducted the drone surveys. WK mainly contributed in all data analysis with software and additional supports from PM and HK. WK wrote the manuscript and figure-making. DH revised the manuscript. All authors have associated works and experiment in the EFForTS-BEE. 


\section{Affiliations of co-authors}

Alexander Röll

Bambang Irawan

Delphine Clara Zemp

Dirk Hölscher

Florian Ellsäßer

Hendrayanto

Holger Kreft

Joyson Ahongshangbam

Leti Sundawati

Paul Magdon
Tropical Silviculture and Forest Ecology, University of Goettingen, Goettingen, Germany

Faculty of Forestry, University of Jambi, Jambi, Indonesia

Biodiversity, Macroecology and Biogeography, University of Goettingen, Goettingen, Germany

Tropical Silviculture and Forest Ecology, Georg-AugustUniversity of Goettingen, Goettingen, Germany

Centre of Biodiversity and Sustainable Land Use, University of Goettingen, Goettingen, Germany

Tropical Silviculture and Forest Ecology, University of Goettingen, Goettingen, Germany

Bogor Agricultural University, Forest Management, Bogor, Indonesia

Biodiversity, Macroecology and Biogeography, University of Goettingen, Goettingen, Germany

Centre of Biodiversity and Sustainable Land Use, University of Goettingen, Goettingen, Germany

Tropical Silviculture and Forest Ecology, University of Goettingen, Goettingen, Germany

Department of Forest Management, Faculty of Forestry, Bogor Agricultural University, Bogor, Indonesia

Forest Inventory and Remote Sensing, University of Goettingen, Goettingen, Germany 


\subsection{References (Chapter 1)}

Abood, S. A., Lee, J. S. H., Burivalova, Z., Garcia-Ulloa, J., \& Koh, L. P. 2015. Relative contributions of the logging, fiber, oil palm, and mining industries to forest loss in Indonesia. Conservation Letters 8 (1): 58-67.

Anderson, K., \& Gaston, K. J. 2013. Lightweight unmanned aerial vehicles will revolutionize spatial ecology. Frontiers in Ecology and the Environment 11 (3): $138-146$.

Avsar, M. D., \& Ayyildiz, V. 2010. Estimation of stand canopy cover by different methods on crown projections: sample of Lebanon cedar stands of the Yavsan Mountain, Kahramanmaras, Turkey. Journal of Applied Sciences 10 (13): 13261330.

Balcomb, J. N. 2015. Sturcture-from-motion based vegetation modeling and shade estimation. Master Thesis. Appalachian State University.

Banu, T. P., Borlea, G. F., \& Banu, C. 2017. Determination of the forest canopy cover using a low-cost commercial drone. Research Journal of Agricultural Science 49 (1): 12-17.

Beckschäfer, P., Seidel, D., Kleinn, C., \& Xu, J. 2013. On the exposure of hemispherical photographs in forests. IForest 6 (4): 228-237.

Birdal, A. C., Avdan, U., \& Türk, T. 2017. Estimating tree heights with images from an unmanned aerial vehicle. Geomatics, Natural Hazards and Risk 8 (2): 11441156.

Bitterlich, W. 1984. The relascope idea. Relative Measurements in Forestry. Farnham Royal: Commonwealth Agricultural Bureaux.

Chianucci, F., Chiavetta, U., \& Cutini, A. 2014. The estimation of canopy attributes from digital cover photography by two different image analysis methods. IForest 7 (4): 255-259.

Chianucci, F., Disperati, L., Guzzi, D., Bianchini, D., Nardino, V., Lastri, C., ... Corona, P. 2016. Estimation of canopy attributes in beech forests using true colour digital images from a small fixed-wing UAV. International Journal of Applied Earth Observation and Geoinformation 47: 60-68.

Chong, K. L., Kanniah, K. D., Pohl, C., \& Tan, K. P. 2017. A review of remote sensing applications for oil palm studies. Geo-Spatial Information Science 20: 184-200.

Chopping, M. 2011. CANAPI: canopy analysis with panchromatic imagery. Remote Sensing Letters 2 (1): 21-29.

Chubey, M. S., Franklin, S. E., \& Wulder, M. A. 2006. Object-based analysis of Ikonos2 imagery for extraction of forest inventory parameters. Photogrammetric Engineering \& Remote Sensing 72 (4): 383-394.

Dandois, J. P., \& Ellis, E. C. 2013. High spatial resolution three-dimensional mapping of vegetation spectral dynamics using computer vision. Remote Sensing of Environment 136: 259-276. 
Dislich, C., Keyel, A. C., Salecker, J., Kisel, Y., Meyer, K. M., Auliya, M., ... Faust, H. 2017. A review of the ecosystem functions in oil palm plantations, using forests as a reference system. Biological Reviews 92 (3): 1539-1569.

FAO. 2016. FAOSTAT online statistical service. Available at: http://faostat.fao.org (Accessed May 31, 2018).

Fitzherbert, E. B., Struebig, M. J., Morel, A., Danielsen, F., Brühl, C. A., Donald, P. F., \& Phalan, B. 2008. How will oil palm expansion affect biodiversity? Trends in Ecology and Evolution 23 (10): 538-545.

Foster, W. A., Snaddon, J. L., Turner, E. C., Fayle, T. M., Cockerill, T. D., Ellwood, M. D. F., ... Yusah, K. M. 2011. Establishing the evidence base for maintaining biodiversity and ecosystem function in the oil palm landscapes of South East Asia. Philosophical Transactions of the Royal Society B 366: 3277-3291.

Jennings, S. B., Brown, N. D., \& Sheil, D. 1999. Assessing forest canopies and understorey illumination: canopy closure, canopy cover and other measures. Forestry 72: 59-74.

Jensen, J. L. R., \& Mathews, A. J. 2016. Assessment of image-based point cloud products to generate a bare earth surface and estimate canopy heights in a woodland ecosystem. Remote Sensing 8 (1).

Kallimani, C. 2016. Tree crown shape parameter extraction from airborne photogrammetric point cloud. Master Thesis. Wageningen University and Research Centre.

Kalantar, B., Mansor, S. B., Sameen, M. I., Pradhan, B., \& Shafri, H. Z. M. 2017. Drone-based land-cover mapping using a fuzzy unordered rule induction algorithm integrated into object-based image analysis. International Journal of Remote Sensing 38: 2535-2556.

Koh, L. P., \& Wilcove, D. S. 2008. Is oil palm agriculture really destroying tropical biodiversity?. Conservation Letters 1 (2): 60-64.

Korhonen, L., Korhonen, K. T., Rautiainen, M., \& Stenberg, P. 2006. Estimation of forest canopy cover: a comparison of field measurement techniques. Silva Fennica 40: $577-588$.

Korhonen, L. 2011. Estimation of boreal forest canopy cover with ground measurements, statistical models and remote sensing. Thesis. University of Eastern Finland.

Lang, M., \& Kurvits, V. 2007. Restoration of tree crown shape for canopy cover estimation. Forestry Studies 46: 23-34.

Leblanc, S. G., \& Fournier, R. A. 2017. "Measurement of forest structure with hemispherical photography," in Hemispherical Photography in Forest Science: Theory, Methods, Applications, eds Fournier, R. A. \& Hall, R. J. (Springer Science + Business Media): 53-84.

Lemmon, P. E. 1956. A spherical densiometer for estimating forest overstory density. Forest Science 2: 314-320.

Li, W., Fu, H., Yu, L., \& Cracknell, A. 2017. Deep learning based oil palm tree detection and counting for high-resolution remote sensing images. Remote Sensing 9 (22). 
Lim, Y. S., La, P. H., Park, J. S., Lee, M. H., Pyeon, M. W., \& Kim, J. I. 2015. Calculation of tree height and canopy crown from drone images using segmentation. Journal of the Korean Society of Surveying, Geodesy, Photogrammetry and Cartography 33 (6): 605-614.

Lin, Y., Hyyppä, J., \& Jaakkola, A. 2011. Mini-UAV-borne LiDAR for fine-scale mapping. IEEE Geoscience and Remote Sensing Letters 8 (3): 426-430.

Mitchell, J. E., \& Popovich, S. J. 1997. Effectiveness of basal area for estimating canopy cover of Ponderosa pine. Forest Ecology and Management 95 (1): 45-51.

Mohan, M., Silva, C. A., Klauberg, C., Jat, P., Catts, G., Cardil, A., ... Dia, M. 2017. Individual tree detection from unmanned aerial vehicle (UAV) derived canopy height model in an open canopy mixed conifer forest. Forests 8.

Nilson, T., \& Peterson, U. 1991. A forest canopy reflectance model and a test case. Remote Sensing of Environment 37 (2): 131-142.

Nunes, M. H., Ewers, R. M., Turner, E. C., \& Coomes, D. A. 2017. Mapping aboveground carbon in oil palm plantations using LiDAR: a comparison of treecentric versus area-based approaches. Remote Sensing 9 (8).

Padfield, R., Drew, S., Syayuti, K., Page, S., Evers, S., Campos-Arceiz, A., Kangayatkarasu, N., ... Tham, M. H. 2016. Landscapes in transition: an analysis of sustainable policy initiatives and emerging corporate commitments in the palm oil industry. Landscape Research 41 (7): 744-756.

Pádua, L., Vanko, J., Hruška, J., Adão, T., Sousa, J. J., Peres, E., \& Morais, R. 2017. UAS, sensors, and data processing in agroforestry: a review towards practical applications. International Journal of Remote Sensing 38: 2349-2391.

Puliti, S., Ørka, H. O., Gobakken, T., \& Næsset, E. 2015. Inventory of small forest areas using an unmanned aerial system. Remote Sensing 7: 9632-9654.

Pretzsch, H., Biber, P., Uhl, E., Dahlhausen, J., Rötzer, T., Caldentey, J., Koike, T., ... Pauleit, S. 2015. Crown size and growing space requirement of common tree species in urban centres, parks, and forests. Urban Forestry and Urban Greening 14 (3): 466-479.

Santos, A. D. M., Mitja, D., Delaître, E., Demagistri, L., Miranda, I. D. S., Libourel, T., \& Petit, M. 2017. Estimating babassu palm density using automatic palm tree detection with very high spatial resolution satellite images. Journal of Environmental Management 193: 40-51.

Santoso, H., Tani, H., \& Wang, X. 2016. A simple method for detection and counting of oil palm trees using high-resolution multispectral satellite imagery. International Journal of Remote Sensing 37 (21): 5122-5134.

Sari, N. A., Sari, M. Y. A., Ahmad, A., Sahib, S. \& Othman, F. 2017. Using LAPER quadcopter imagery for precision oil palm geospatial intelligence (OP GeoInt). Journal of Telecommunication, Electronic and Computer Engineering 10 (1): 2533. 
Shamshiri, R. R. 2018. A lecture note on unmanned aerial vehicles (UAV) to support precision agriculture research in oil palm plantations. Available at: http://www.academia.edu/33445059/A_Lecture_note_on_Unmanned_Aerial_Ve hicles_UAV_to_Support_Precision_Agriculture_Research_in_Oil_Palm_Plantat ions (Accessed December 10, 2018).

Shin, P., Sankey, T., Moore, M. M., \& Thode, A. E. 2018. Evaluating unmanned aerial vehicle images for estimating forest canopy fuels in a Ponderosa pine stand. Remote Sensing 10.

Srestasathiern, P., \& Rakwatin, P. 2014. Oil palm tree detection with high resolution multi-spectral satellite imagery. Remote Sensing 6 (10).

Teuscher, M., Gérard, A., Brose, U., Buchori, D., Clough, Y., Ehbrecht, M., ... Kreft, H. 2016. Experimental biodiversity enrichment in oil-palm-dominated landscapes in Indonesia. Frontiers in Plant Science 7.

Tang, L., \& Shao, G. 2015. Drone remote sensing for forestry research and practices. Journal of Forestry Research 26 (4): 791-797.

Tichý, L. 2016. Field test of canopy cover estimation by hemispherical photographs taken with a smartphone. Journal of Vegetation Science 27 (2): 427-435.

Tomaštík, J., Mokroš, M., Saloš, S., Chudỳ, F., \& Tunák, D. 2017. Accuracy of photogrammetric UAV-based point clouds under conditions of partially-open forest canopy. Forests 8 .

Trochta, J., Kruček, M., Vrška, T., \& Kraâl, K. 2017. 3D Forest: an application for descriptions of three-dimensional forest structures using terrestrial LiDAR. PLoS ONE 12 (5).

Tugi, A., Rasib, A. W., Suri, M. A., Zainon, O., Yusoff, A. R. M., Rahman, M. Z. A., Sari, N. A., \& Darwin, N. 2015. Oil palm tree growth monitoring for smallholders by using unmanned aerial vehicle. Jurnal Teknologi 26: 17-27.

Vaughn, N., \& Ritchie, M. W. 2005. Estimation of crown cover in interior ponderosa pine stands: effects of thinning and prescribed fire. Western Journal of Applied Forestry 20: 240-246.

Wallace, L., Lucieer, A., Malenovskỳ, Z., Turner, D., \& Vopěnka, P. 2016. Assessment of forest structure using two UAV techniques: a comparison of airborne laser scanning and structure from motion (SfM) point clouds. Forests 7: 1-16.

Weiss, M., \& Baret, F. 2016. Can_eye v6.4.6 user manual. Available online at: https://www6.paca.inra.fr/can-eye/Documentation/Documentation (Accessed March 10, 2017).

Westoby, M. J., Brasington, J., Glasser, N. F., Hambrey, M. J., \& Reynolds, J. M. 2012. 'Structure-from-Motion' photogrammetry: a low-cost, effective tool for geoscience applications. Geomorphology 179: 300-314.

Wicke, B., Sikkema, R., Dornburg, V., \& Faaij, A. 2011. Exploring land use changes and the role of palm oil production in Indonesia and Malaysia. Land Use Policy 28 (1): 193-206. 
Zhang, H., Morison, J. I. L., \& Simmonds, L. P. 1999. Transpiration and water relations of poplar trees growing close to the water table. Tree Physiology 19 (9): 563-573.

Zhang, J., Hu, J., Lian, J., Fan, Z., Ouyang, X., \& Ye, W. 2016. Seeing the forest from drones: testing the potential of lightweight drones as a tool for long-term forest monitoring. Biological Conservation 198: 60-69. 


\section{Chapter 2}

\section{Drone-based photogrammetry derived crown metrics for predicting tree and oil palm water use}

Joyson Ahongshangbam*1, Watit Khokthong*1, Florian Ellsäßer ${ }^{1}$, Hendrayanto ${ }^{2}$, Dirk Hölscher ${ }^{1,3}$, Alexander Röll ${ }^{1}$

${ }^{1}$ Tropical Silviculture and Forest Ecology, University of Goettingen, Goettingen, Germany

${ }^{2}$ Bogor Agricultural University, Forest Management, Indonesia

${ }^{3}$ Centre of Biodiversity and Sustainable Land Use, University of Goettingen, Goettingen, Germany

* The authors contributed equally to the manuscript

Correspondence: Joyson Ahongshangbam, E-mail: jahongs@gwdg.de

In revision at Ecohydrology 


\begin{abstract}
Transpiration at the stand level is often estimated from water use measurements on a limited number of plants and then scaled up by predicting the remaining plants of a stand by plant size related variables. Today, drone-based methods offer new opportunities for plant size assessments. We tested crown variables derived from dronebased photogrammetry for predicting and scaling plant water use. In an oil palm agroforest and an oil palm monoculture plantation in lowland Sumatra, Indonesia, tree and oil palm water use rates were measured by sap flux techniques. Simultaneously, aerial images were taken from an octocopter equipped with an RGB camera. We used the structure from motion approach to compute several crown variables such as crown length, width and volume. Crown volumes for both palms (69\%) and trees (81\%) explained much of the observed spatial variability in water use; however, the specific crown volume model differed between palms and trees and there was no single linear model fitting for both. Among the trees, crown volume explained more of the observed variability than stem diameter, and in consequence, uncertainties in stand level estimates resulting from scaling were largely reduced. For oil palms, an appropriate whole-plant size related predictor variable was thus far not available. Stand level transpiration estimates in the studied oil palm agroforest were lower than those in the oil palm monoculture, which is probably due to the small-statured trees. In conclusion, we consider drone-derived crown metrics very useful for the scaling from single plant water use to stand-level transpiration.
\end{abstract}

Keywords: agroforest, bootstrapping, sap flux, scaling, structure from motion, transpiration, uncertainty 


\subsection{Introduction}

Transpiration is a central flux in the ecosystem water cycle. In forests or similar vegetation types, it is often estimated from individual plant water use assessments, for example with sap flux techniques (Granier 1985; Wullschleger et al. 1998). In most studies, the number of plants directly analyzed for water use is lower than the number of plants in the stand. The individual plant water use rates are then scaled to stand-level transpiration by biometric variables. Scaling is thus a critical issue that needs to be optimized in order to improve transpiration estimates and to reduce associated uncertainties (Hatton and Wu 1995; Jarvis 1995; Moore et al. 2017).

Candidate variables for scaling include tree diameter, crown metrics and leaf area. Among these, tree diameter and the number of trees (stand density) are often used, as they are easy to assess and often available from forest inventories. The relationships between tree water use and tree diameter often have $\mathrm{R}^{2}$ values around 0.66 (Yue et al. 2008; Schiller et al. 2007), but closer (Wang et al. 2006) and less close correlations (Kume et al. 2009) have also been observed. Stem diameter has some limitations that include a potentially slow response to concurrent dynamics in the stand such as crown damages or crown expansions into gaps. In addition, recently increasingly monocot species such as bamboos and palms came into the focus of transpiration studies (Röll et al. 2015; Mei et al. 2016), in which intra-specific diameter variation may be low but nonetheless variation in water use occurs. Leaf area index can be a very powerful variable for scaling (Hatton and Wu 1995; Vertessy et al. 1995; Medhurst et al. 2002), but it is often only available at the stand level and not at the tree level. In contrast, crown dimensions are easier to measure and thus more commonly available and yielded good results in mature oak (Quercus robur) forest (Čermák 1989). Similarly, in Taxodium distichum forest and olive orchard, crown structure correlated closely with tree water use (Oren et al. 1999; López-Bernal et al. 2010). Crown exposure also indirectly affected transpiration by influencing leaf wetness and dryness in a premontane forest of Costa Rica (Aparecido et al. 2016).

Despite the long-recognized potential of crown variables for scaling up from tree water use to stand transpiration, diameter based approaches remain popular, as crown variables are more difficult and time consuming to assess in ground-based stand inventories. With the recent development of drone technologies and their application in ecological studies this might change. Drones equipped with optical detectors such as cameras capturing specific light wave lengths or laser-based approaches offer new opportunities for crown and canopy assessments (Díaz-Varela et al. 2015; Thiel and Schmullius 2016; Barnes et al. 2017). Crown variables such as crown length (Kallimani 2016), crown diameter (Lim et al. 2015; Panagiotidis et al. 2016) or crown volume (Torres-Sánchez et al. 2015) were calculated using photogrammetric techniques. Even though drone technologies have previously been applied in ecohydrological studies (Vivoni et al. 2014), the applicability of drone-based photogrammetry for scaling up tree water use to stand-level transpiration has to our knowledge not yet been explored. 
Uncertainties associated with sap flux measurements and stand level estimates of transpiration are manifold and include the assessment of sap flux variation in a given tree, the number of trees sampled, and the scaling (Peters et al. 2018). For a better understanding of ecohydrological consequences with land-use and land-cover change, it will be important to produce stand-level transpiration estimates with a high accuracy and thus, a low associated uncertainty. The basis for this is the further optimization of current sampling and scaling schemes, potentially also by employing innovative dronebased methods.

In our study, we assessed relationships between crown metrics and the water use of oil palms and trees in lowland Sumatra, Indonesia. In this region, natural forests have largely been converted and monoculture oil palm plantations are widespread (Drescher et al. 2016). The land cover change and the expansion of oil palm plantations are associated with losses of biodiversity and impaired ecosystem functions (Barnes et al. 2014; Clough et al. 2016; Dislich et al. 2017). Transpiration rates from commercial oil palm plantations can be high and may exceed those of remaining forests (Röll et al. 2015, Meijide et al. 2018). To test possibilities of alleviating the ecological impacts of oil palm cultivation, a biodiversity enrichment experiment, Efforts-BEE, was set up in a commercial oil palm plantation by planting native tree species and establishing oil palm agroforests (Teuscher et al. 2016). Within Efforts-BEE, we conducted our study on plant water use and scaling by crown variables. The objectives were (1) to test drone derived crown variables for the prediction of tree and palm water use, (2) to analyze uncertainties resulting from scaling plant water use to stand-level transpiration, and (3) to compare transpiration rates of an oil palm monoculture to an oil palm agroforest.

\subsection{Methods}

\subsubsection{Study area and sites}

The study was conducted in Jambi province, Sumatra, Indonesia. The region is tropical humid, with mean annual precipitation of $2235 \mathrm{~mm} \mathrm{yr}^{-1}$ and average annual temperature of $26.7^{\circ} \mathrm{C}$ (Drescher et al. 2016). The study sites were located just south of the equator $\left(01.95^{\circ} \mathrm{S}\right.$ and $\left.103.25^{\circ} \mathrm{E}\right)$, within the commercial oil palm plantation PT Humusindo, near Bungku village. Mean elevation is $47 \mathrm{~m}$ asl. The biodiversity enrichment experiment (EFForts-BEE) was established in monoculture oil palm plantations. Oil palms were planted in a $9 \mathrm{~m} \mathrm{x} 9 \mathrm{~m}$ triangular grid resulting in approx. 143 oil palms per hectare; the age of the oil palms at the time of study was approx. 9-15 years (Teuscher et al. 2016). The broad age range refers to the entire experiment with 56 plots that covers an area of about $150 \mathrm{ha}$. After thinning of oil palms, six native tree species were planted in a $2 \mathrm{~m} \times 2 \mathrm{~m}$ grid. The tree species were mixed in a way to maximize the number of hetero-specific neighbors (i.e. no con-specific rows or groups) (Teuscher et al. 2016). There are 52 experimental plots varying in plot size and in tree species diversity level. In addition, there are also 4 control plots with oil palm management as usual, and no enrichment planting. Our main study site was at a $40 \mathrm{~m}$ by $40 \mathrm{~m}$ plot with six tree 
species planted (Figure 2.1) and a nearby monoculture control plot of the same size. The agroforest plot was selected based on the criteria plot size (as big as possible, i.e. $40 \mathrm{~m}$ by $40 \mathrm{~m}$ ) and highest tree diversity level (six tree species). The monoculture control plot was located approx. $60 \mathrm{~m}$ away from the agroforest plot. At the selected agroforest and monoculture study plot, oil palms were of similar age. In the agroforest, the studied oil palms had an average meristem height of $6.8 \pm 0.2 \mathrm{~m}$ (mean $\pm \mathrm{SD}$ ), while the sample trees had an average height of $4.7 \pm 0.6 \mathrm{~m}$ (Appendix Table 1). The reported measurements were conducted between September and November 2016, which was the beginning of the rainy season.

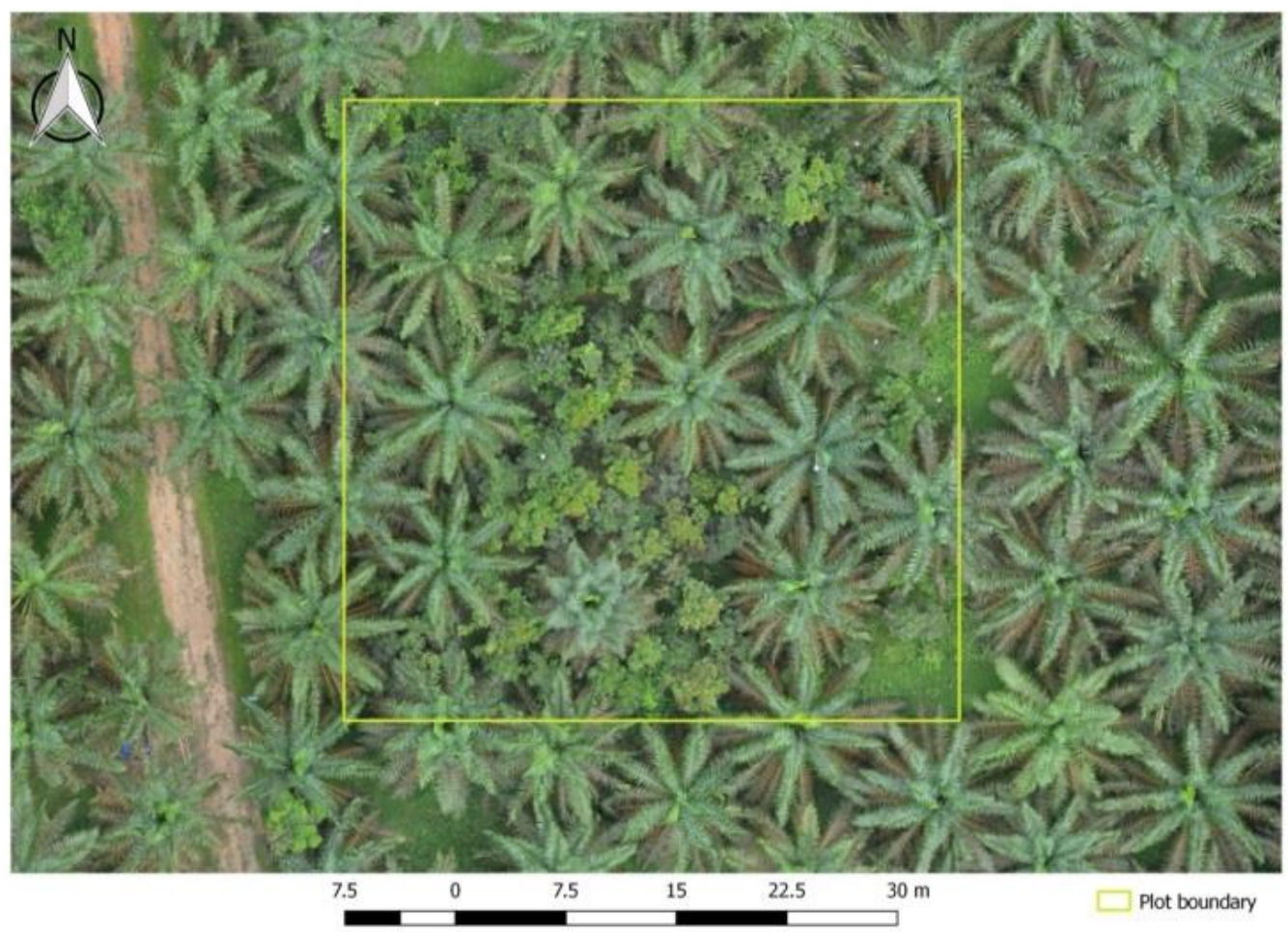

Figure 2.1. Aerial view of a studied oil palm agroforestry plot. Three years prior to the study, the stand was thinned with reduction in oil palm stems by $40 \%$, and six tree species were planted. 


\subsubsection{Sap flux measurements}

Eight palms and 16 trees were equipped with sap flux sensors. Selected tree species were Archidendron pauciflorum, Parkia speciosa, Peronema canescens and Shorea leprosula. As Shorea leprosula did not perform well on the multi-species plot, it was measured on a nearby single tree species enrichment plot, under otherwise very similar conditions. One further tree species, Dyera polyphylla, was not included in the measurements because almost all individuals had died on the multi-species plot and no plot with well performing Dyera polyphylla trees was available nearby. Archidendron pauciflorum, Parkia speciosa and Peronema canescens are early successional and light demanding species (Aumeeruddy 1994; Lee et al. 2002; Orwa et al. 2009; Lawrence 2001); Shorea leprosula is considered a gap opportunist (Ådjers et al. 1995; Bebber et al. 2002). Sap flux sensors were installed in four trees for each tree species and on four oil palms in an oil palm agroforest, and additionally on four oil palms in the oil palm monoculture.

For trees, we used heat ratio method sensors (HRM, Burgess et al. 2001; ICT International, Australia). One HRM sensor per tree was installed radially into the xylem at breast height. To process raw data we used the software Sap Flow Tool, version 1.4.1 (ICT International, Australia). The mean sap velocity output data was converted into 'sap flow' $\left(\mathrm{cm}^{3} \mathrm{~h}^{-1}\right)$ by multiplying it with the cross-sectional water conductive area $A_{c}$ $\left(\mathrm{cm}^{2}\right)$. As the studied trees were rather small (diameter at breast height, DBH $<11 \mathrm{~cm}$ ), we considered $A_{c}$ to be equal to the cross-sectional area at breast height. Estimation errors associated with assuming fully conductive cross-sectional areas of the relatively small trees for the up-scaling to tree water use are likely to be small; for similar sized trees Delzon et al. (2004) found a difference of approx. 4\% with this assumption.

For oil palms, we used thermal dissipation probes (TDP, Granier 1985) as this method had previously been tested on oil palm and a sampling scheme had been developed (Niu et al. 2015), which we followed closely. Like Niu et al. (2015), we installed the TDP sensors in leaf petioles rather than the stem of oil palms due to presumably higher vessel density and homogeneity in vascular bundle distribution. Niu et al. (2015) also tested the influence of leaf characteristics such as leaf orientation, inclination and horizontal shading on leaf water use for 56 oil palm leaves, but no statistically significant effects were observed. The authors argued that the examined factors partly counteract (Niu et al. 2015). We followed their suggested scheme in our study and selected four leaves per palm in the cardinal directions. Sap flux density $J_{s}\left(\mathrm{~g} \mathrm{~cm}^{-2} \mathrm{~h}^{-1}\right)$ was calculated using the equation derived by Granier (1985), but with oil palm specific, calibrated equation parameters (Niu et al. 2015). Zero-flux conditions were examined following Oishi et al. (2008); it was found that zero-flux conditions were met during the early morning hours during our entire sap flux measurement period. Individual leaf water use rates $\left(\mathrm{kg}\right.$ day $^{-1}$ ) were calculated by multiplying $J_{\mathrm{s}}$ daysums by $A_{c}$ of the according leaf petioles. Those were derived from a previously presented linear relationship between petiole baseline length (which was measured with a caliper) and $A_{c}$ at the location of the sensor (Niu et al. 2015). Individual daily leaf water use rates were averaged for each 
palm and multiplied by the number of leaves per palm to derive palm water use rates $\left(\mathrm{kg} \mathrm{day}^{-1}\right)$. Water use rates were based on averages of three sunny days on which soil moisture was non-limiting in order to minimize the effects of varying environmental conditions; this approach is in accordance with previous research on oil palm water use (e.g. Niu et al. 2015; Röll et al. 2015). In the nomenclature across the applied sap flux methods, we follow Edwards et al. (1997) in expressing individual tree and oil palm water use as mass per time $\left(\mathrm{kg} \mathrm{day}^{-1}\right)$ and stand-scale transpiration in ' $\mathrm{mm}$ day $^{-1}$ '.

\subsubsection{Drone image acquisition and processing}

At the time of the sap flux measurements, drone flights were conducted using an octocopter (MikroKopter OktoXL, HiSystems GmbH, Germany) equipped with a digital RGB camera (Nikon D5100, Japan). Flight routes were planned with MikroKopter-Tool V2.14b. Flight altitude was $39 \mathrm{~m}$ above ground, flight speed was $7.2 \mathrm{~km} \mathrm{~h}^{-1}$ and one picture was taken per second (Appendix Table 2).

The flight missions were performed in circular and grid pathways to get different perspectives and an overlap of $70 \%$ for the construction of 3D maps. After eliminating blurry pictures, 3D point clouds were created from an average of 600 geo-referenced images per study site with Agisoft Photoscan Professional 1.2.6 software (Agisoft LLC, Russia). The achieved point cloud density was 3 points $\mathrm{cm}^{-2}$. In the analysis, we used the pictures from one single flight to construct the $3 \mathrm{D}$ models.

The workflow included image alignment, georeferencing, building dense point clouds, the generation of digital elevation models (DEM) and orthomosaic generation. Groundcontrol points printed as 8-Bit barcodes and laid out during the flight campaigns were used to determine the overall positional accuracy of orthomosaic images. The 3D point clouds were generated using the Structure from Motion (SfM) technique (Westoby et al. 2012; Lowe 2004). Orthomosaic and digital elevation models (DEM) were created for each plot for further visualization and interpretation.

In order to create canopy height models (CHM), digital terrain models (DTM) were generated from the point cloud data. For this, the three main parameters (maximum angle, maximum distance and cell size) were defined with Agisoft's ground point classifier tool and used to differentiate ground and non-ground points. The classified ground points were converted to raster format as DTM. Further, we overlaid the DEM and DTM and applied smooth filters to derive the canopy height model. Subsequently, crown polygons were delineated for target trees and oil palms through visual interpretation and tree location information. One major challenge of using aerial imagery for delineating individual tree canopies is the overlapping of crowns. It was not a major issue in our study as the studied trees are young and located in gaps created by the previous thinning of oil palms. The 3D crown models of the studied palms and trees (extracted from the SfM point clouds) were derived from multiple shots at different angles and positions, thus allowing to delineate even overlapping canopies. Additionally, the very high point cloud density of 3 points $\mathrm{cm}^{-2}$ allowed modeling the 
crown structures in great detail. However, for some sample trees we experienced difficulties with automatic 3D segmentation, e.g. when branches from different trees connect (Tao et al 2015). In such a case, we performed additional manual segmentation and processing and added clusters for the automatic approach (Trochta et al. 2017). The individual canopy height of trees and meristem height of oil palms were obtained by overlaying individual crown polygons with the CHM. For trees, the highest point in CHM within the individual crown polygon was considered as the canopy height of trees (Birdal et al. 2017), while the lowest point was taken as the meristem height of oil palms. As a ground-based reference, canopy height of each individual was measured using a pole, and canopy width and projection area were established with the vertical sighting method (Preuhsler 1979, also see Pretzsch et al. 2015) in the eight cardinal directions. The heights obtained by the drone-based and the ground-based methods were well correlated along a 1:1 line $\left(\mathrm{R}^{2}=0.69, \mathrm{P}<0.001\right.$; Appendix Figure 1). Also, the canopy diameter obtained by terrestrial measurements and drone based analyses were highly correlated along a $1: 1$ line $\left(\mathrm{R}^{2}=0.95, \mathrm{P}<0.001\right)$, suggesting the applicability of the drone based approach. The PolyClip function in Fusion software v3.6 (USDA, USA) was used to extract individual point clouds for each tree and oil palm crown. Crown variables of each individual were obtained using measurement marker functions in the same software. For crown volume and planar area, the point clouds were interpolated in R software v3.4.3 (R Development Core team, 2016) using the Alphashape3D (Lafarge and Pateiro-Lopez 2014) and rLiDAR (chullLiDAR2D, Silva et al. 2017) packages, respectively.

There are several different ways to compute crown volumes including convex hull and alpha shape algorithms (Colaço et al. 2017). In convex hull, it constructs an envelope by considering the number of input points belongs to the convex hull to represent the outward curving shape of tree crowns. In the alpha shape approach, a predefined and reduced alpha value serves as size criterion to construct more details, thus shrinking the corresponding convex hull closer down to the 3D point cloud (Pateiro-Lopez and Rodriguez-Casal 2010; Colaço et al. 2017). In our study, we calculated the crown volumes for both trees and oil palms with a convex hull algorithm and alpha shape algorithms, the latter using the alpha values $0.75,0.50$ and 0.25 (Appendix Figure 2). Two contrasting models (convex hull and alpha shape 0.25 ) are illustrated in Figure 2.2 for a studied oil palm and a studied tree. 
Oil palm

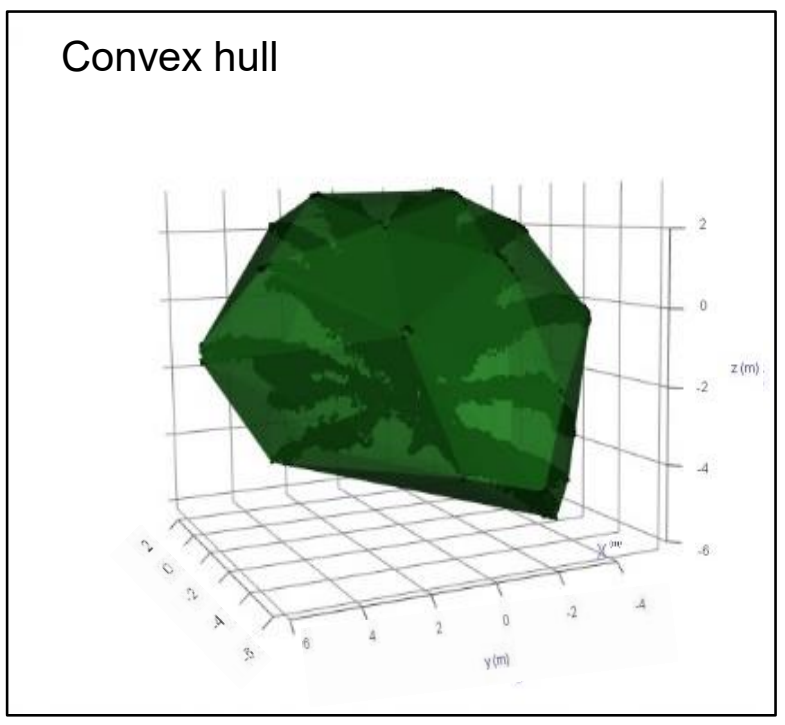

\section{Alpha 0.25}

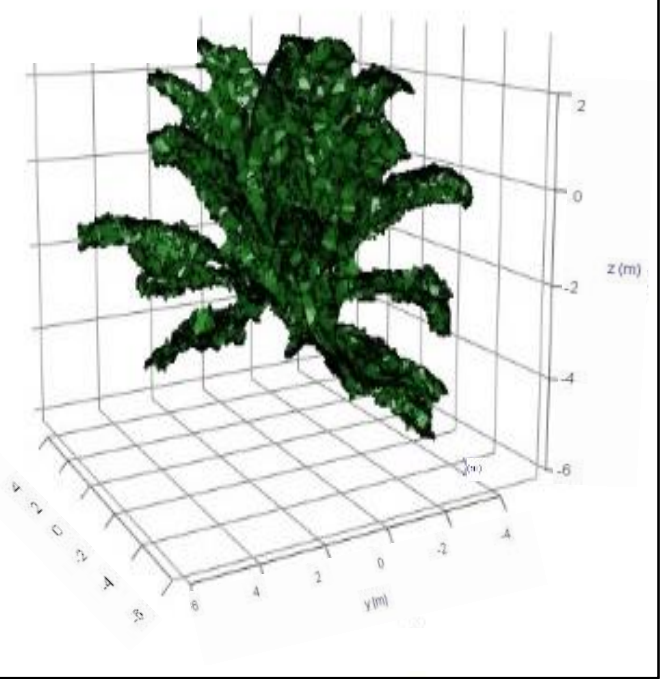

Tree: Shorea leprosula

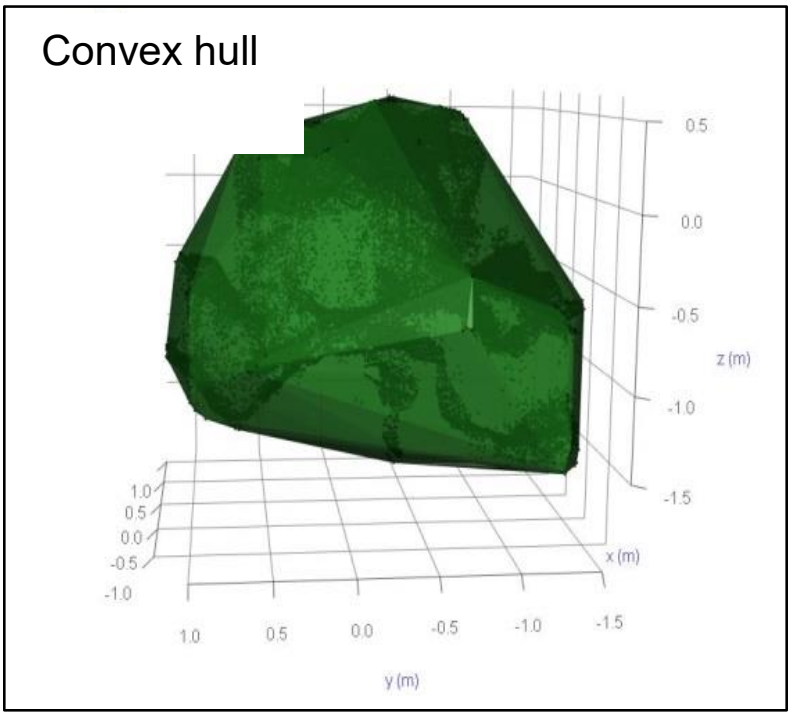

Alpha 0.25

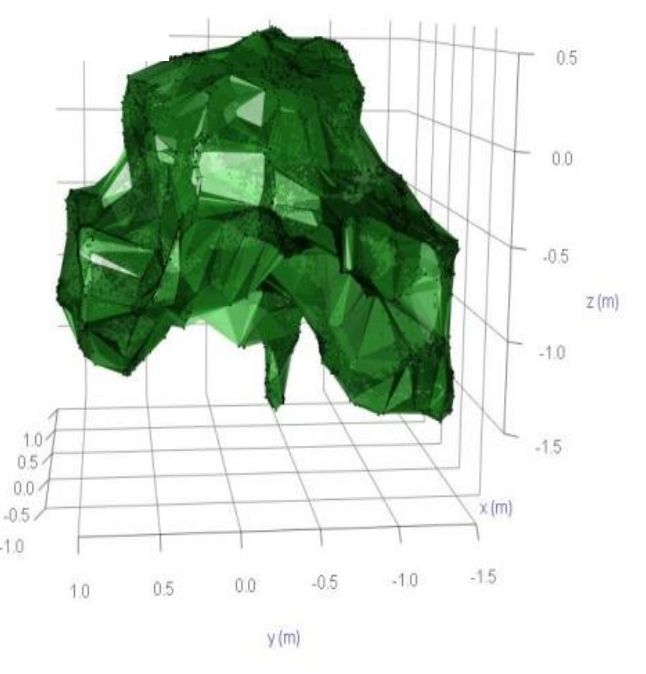

Figure 2.2. Canopy of an oil palm and a tree (Shorea leprosula) using point clouds from the drone missions and convex hull and alpha shape algorithms. Other tree species are shown in Appendix Figure 2. 


\subsubsection{Statistical analyses}

To test for differences in tree water use among species, and for differences in oil palm water use between oil palm agroforest and oil palm monoculture, we used ANOVAs, followed by Posthoc Tukey's HSD; differences were assumed as significant at $\mathrm{P}<0.05$.

Plant size related variables such as crown volumes as predictor of plant water use were tested by linear regressions. We tested the variance of residuals for normal distribution by the Shapiro-Wilk test and homoscedasticity with residual plot analysis. The null hypothesis of normality was rejected at $\mathrm{P}<0.05$.

The linear regressions served as the basis for subsequent scaling of tree- and palm-level water use to stand-level transpiration. To compare the uncertainties associated with different scaling variables, we performed parametric bootstrapping with the linear relationships between water use and the predictor variables with 50,000 iterations using the R package 'boot' (Canty and Ripley 2017; Davison and Hinkley 1997). This yielded estimates of means and corresponding standard deviations as measures of uncertainty.

All statistical analyses and plotting were performed with $\mathrm{R}$ version 3.4 .3 ( $\mathrm{R}$ Development Core team, 2016).

\subsection{Results}

\subsubsection{Plant water use}

On sunny days, the daily water use per palm ranged between 158 and $249 \mathrm{~kg} \mathrm{day}^{-1}$, and on average was by $32 \%$ higher in the agroforest than in the monoculture (ANOVA, $\mathrm{P}$ $<0.01)$. Daily water use of the inter-planted trees was much lower and per tree ranged from 1.1 to $19.8 \mathrm{~kg} \mathrm{day}^{-1}$. There were species-specific differences among the trees $(\mathrm{P}<$ 0.001) (Appendix Table 1).

\subsubsection{Drone-derived crown metrics and their relation with plant water use}

Crown volumes (convex hull) for the eight oil palms with sap flux measurements ranged between 332 and $831 \mathrm{~m}^{3}$, and on average were by $79 \%$ higher in the agroforest than in the monoculture. Crown volumes (convex hull) of the trees were much lower and ranged between 0.95 and $81.0 \mathrm{~m}^{3}$. There were species-specific differences among the trees (Appendix Table 1).

Crown metrics were highly correlated with tree and palm water use (Table 2.1). For oil palm, crown volume convex hull explained $69 \%$ of the observed palm-to-palm variability in daily water use $(\mathrm{P}=0.01)$. For trees, crown volume models with an alpha level 0.25 (Appendix Figure 2) explained $81 \%$ of tree-to-tree variability $(\mathrm{P}<0.001)$ (Figure 2.3) across the studied species. Due to violated quality criteria (Shapiro-Wilk test, $\mathrm{P}=0.000042$ ), there was however no single linear crown volume model that fit 
both oil palms and trees. Nonetheless, the single linear relationship crown volume alpha 0.75 to tree/palm water use is depicted in Appendix Figure 3.

For trees, stem diameter as measured in ground-based inventories explained $65 \%$ of the variability observed in daily tree water use $(\mathrm{P}<0.01)$ while for oil palms no significant ground-based explanatory variables were available for comparison

Table 2.1. Linear regressions between daily water use $\left(\mathrm{kg} \mathrm{day}^{-1}\right)$ and different aerial and ground based variables of oil palms $(n=8)$ and trees $(n=15)$. Only those linear regression which satisfy normality and homoscedasticity conditions are presented.

\begin{tabular}{|c|c|c|c|c|c|}
\hline & & & $\begin{array}{l}\text { Equation } \\
b_{0} \text { - water use } \\
b_{1} \text { - variables }\end{array}$ & $P$ value & $\mathbf{R}^{2}$ \\
\hline \multicolumn{6}{|l|}{ Drone based } \\
\hline \multirow[t]{5}{*}{ Crown volume $\left(\mathrm{m}^{3}\right)$} & Oil palms & convex hull & $b_{0}=0.14 b_{1}+122$ & $P=0.010$ & 0.69 \\
\hline & & alpha 0.75 & $b_{0}=0.74 \quad b_{1}+49.1$ & $\mathrm{P}=0.038$ & 0.53 \\
\hline & Trees & alpha 0.75 & $b_{0}=0.39 b_{1}+2.12$ & $\mathrm{P}<0.001$ & 0.73 \\
\hline & & alpha 0.5 & $b_{0}=0.51 \quad b_{1}+1.84$ & $\mathrm{P}<0.001$ & 0.77 \\
\hline & & alpha 0.25 & $b_{0}=0.82 b_{1}+1.70$ & $\mathrm{P}<0.001$ & 0.81 \\
\hline \multicolumn{6}{|l|}{ Ground based } \\
\hline \multirow[t]{2}{*}{$\mathrm{DBH}(\mathrm{cm})$} & Oil palms & & - & - & - \\
\hline & Trees & & $b_{0}=2.46 \quad b_{1}-8.42$ & $\mathrm{P}<0.01$ & 0.65 \\
\hline
\end{tabular}



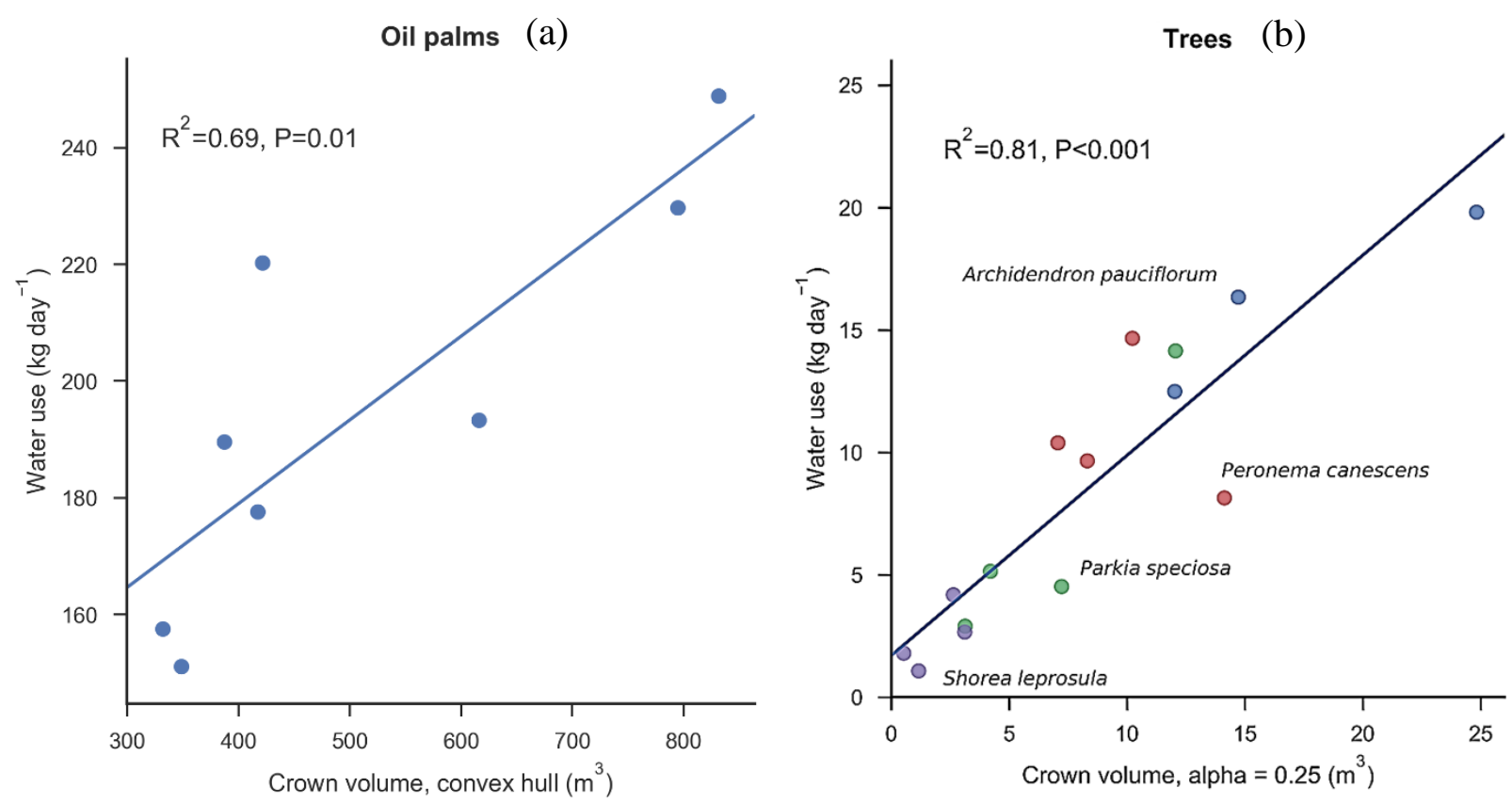

Figure 2.3. Daily water use of oil palms (a) and trees (b) versus crown volumes. Note the different crown volume models and scales. 


\subsubsection{Transpiration estimates and uncertainties}

Based on scaling with crown volumes, the stand-level transpiration estimate in the oil palm agroforest is $1.9 \mathrm{~mm}_{\text {day }}{ }^{-1}$ and $3.0 \mathrm{~mm} \mathrm{day}^{-1}$ in the oil palm monoculture (Table 2.2). Scaling with ground-based DBH measurements in trees resulted in only minor differences in stand transpiration estimates. For trees, bootstrapping suggests that the estimate based on crown volume is associated with an uncertainty due to scaling of $28 \%$. In contrast, using diameter for scaling results in an uncertainty of $100 \%$. For the oil palms in the agroforest and the monoculture, the uncertainty estimates associated with crown volume scaling were $37 \%$ and $35 \%$, respectively.

Table 2.2. Transpiration of the oil palm agroforest and monoculture plot with uncertainties for the scaling from individual plants to the plot level by bootstrapping linear relationships. For uncertainty estimates from ground-based scaling in oil palm we used an approach by Niu et al. (2015), which is based on the number of leaves that measurements were performed on and the resulting cumulative coefficient of variation (marked with an *).

\section{Transpiration}

$$
\left(\mathrm{mm} \text { day }^{-1}\right)
$$

Estimate \pm uncertainty

Drone-based

Agroforest

Trees

$0.28 \pm 0.08$

Oil palms

$1.61 \pm 0.61$

Total

$1.89 \pm 0.69$

Monoculture

Oil palms

$3.04 \pm 1.05$

Ground-based

Agroforest

Trees

$0.38 \pm 0.38$

Oil palms

$1.67 \pm 0.88 *$

Total

$2.05 \pm 1.26$

Monoculture

Oil palms

$2.96 \pm 0.78^{*}$ 


\subsection{Discussion}

In our study, we found that drone-based assessments of oil palm and tree crowns predicted individual plant water use quite well and better than e.g. diameter in trees, and thus led to reduced uncertainties in spatial scaling and stand-level estimates of transpiration.

A popular variable for the prediction of plant water use is stem diameter. In our study, DBH yielded an $\mathrm{R}^{2}$ of 0.65 , which is quite similar to several recent studies (Yue et al. 2008; Schiller et al. 2007; Granier et al. 2000). In our study as in many others, the relationship between DBH and tree water use was found to hold across species. In contrast, in a premontane forest in Costa Rica the correlation of water use to DBH showed differences among species (Moore et al. 2017). Likewise, species-specific trajectories were suggested from reforestations in the Philippines (Dierick and Hölscher 2009). There are further general concerns in using diameter for scaling. As such, diameter integrates over large time spans and a tree may have achieved its diameter under conditions that no longer prevail at the time of study. Cases in point are damages by storm or lightning, or in the other direction crown expansion into a gap that was formed by the dieback of a neighbor.

Our study also included oil palm, a monocot plant which lacks secondary diameter growth. Consequently, significant correlations between stem diameter and water use can hardly be expected. Thus far, to our knowledge no scaling scheme from an individual oil palm to the stand level had been established. Based on leaf level measurements in 56 oil palm leaves, Niu et al (2015) tested for relationships between leaf characteristics (e.g. orientation, inclination, horizontal shading) and leaf water use but did not find significant relationships. In contrast, the approach of our study with crown volume and whole plant water use resulted in an $\mathrm{R}^{2}$ of $0.69(\mathrm{P}=0.01)$. Based on their results, Niu et al. (2015) suggested a non-stratified sampling scheme. Our results would suggest that a sampling scheme in oil palm would benefit from representing different crown dimensions.

For trees and palms the best fitting (as based on high $\mathrm{R}^{2}$ and low $\mathrm{P}$ ) crown volume model differed with alpha 0.25 for trees and convex hull for palms. There was however one single intermediate crown volume model, alpha 0.75 , that appears suitable for both trees and palms (Table 2.1). However, applying this model for the pooled dataset of all trees and palms resulted in non-normality and too high heteroscedascity to be accepted (Shapiro-Wilk test, $\mathrm{P}=0.000042$ ), even though $\mathrm{R}^{2}$ was very high and the $\mathrm{P}$ value was low (Appendix Figure 3). Our dataset certainly lacks values in the mid-range of crown volume and water use for a further examination of this 'universal' crown model. Also, it can be seen that crown alpha 0.75 is not the best predictor for oil palm water use. However, the universal model may indicate that trees and oil palms do not differ significantly in water use per crown volume, even though more and more equally distributed data will be needed to further test this contention. On the other hand, it may also well be that a universal crown volume to plant water use relationship does not exist. 
As such, across (tree) species, e.g. when comparing early successional and late successional species, substantial differences regarding crown shape, the occurrence of sun and shade leaves and leaf stomatal conductance exist (Bazzaz 1979; Poorter et al. 2006).

Sap flux measurements and subsequent scaling up to the stand level are associated with a multitude of uncertainties, including the positioning and number of a sensor in a given plant, methods of zero-flow conditions and sensor calibration (Peters et al. 2018), as well as the number of plants studied. Our study addresses the spatial scaling from the individual plant to the stand. The uncertainty estimates as the result of the applied bootstrapping are directly related to the explained variance in the linear relationships with water use. They suggest that for trees the uncertainty of the stand-level estimate is $28 \%$ with drone-based imagery, whereas it is $100 \%$ with ground-based diameter measurements. The drone-based approach thus has at least one clear advantage. For oil palms, our reported uncertainty of $37 \%$ is the first estimate that to our knowledge addresses whole-plant to stand scaling. However, Niu et al. (2015) estimated that counting leaves per oil palm and oil palms per stand, and scaling based on sap flux measurements in 12 leaves, would result in uncertainty of stand-level transpiration of $14 \%$. For oil palms it thus seems that the previously proposed ground-based method has an advantage. Nonetheless, the crown dimension approach is still valuable, as it may also allow to estimate water use across different conditions. For example, in our case an oil palm stand was thinned and trees were inter-planted in gaps three years prior to the study (agroforest), whereas the control stand remained untreated (monoculture). We found significant differences in crown volume and water use of the studied oil palms, but the two variables were significantly related to each other across treatments. The ground-based leaf-count approach, on the other hand, was previously only tested in one single stand with homogenous conditions. Their applicability will have to be tested further in follow-up studies focusing on how to best assess (and reduce) such estimation uncertainties.

The crown volumes in our study were derived from RGB images and a photogrammetric approach. Other drone-derived structural variables such as height and projected crown area show a high correlation with ground-based reference measurements along a 1:1 line, suggesting the applicability of the aerial method. The point cloud density in our study was 3 points $\mathrm{cm}^{-2}$, which can be regarded as quite high and compares to or is even higher than those that result from laser scanning (Vauhkonen et al. 2014). Drone-based imagery performs particularly well for the upper part of the canopy, which is also where a large part of the transpiration takes place. So far, we only tested this method in a relatively simply structured monoculture and an oil palm agroforest with relatively young trees. As we regard the results as promising, it will be interesting to test it in more heterogeneous stands in next step.

Oil palm water use in the studied monoculture and the agroforest ranged between 158 and $249 \mathrm{~kg} \mathrm{day}^{-1}$. The studied monoculture is relatively intensively managed, with fertilizer application including $230 \mathrm{~kg} \mathrm{~N} \mathrm{ha}^{-1} \mathrm{year}^{-1}$ (Teuscher et al. 2016). The observed 
water use rates exceed those of small-holder plantations of similar age (108 $\pm 8 \mathrm{~kg}^{\text {day }}$ ${ }^{1}$, mean \pm SE among eight sites) and compare to values from another intensively managed, commercial oil palm monoculture plantation in the region $\left(178 \pm 5 \mathrm{~kg} \mathrm{day}^{-1}\right)$ (Röll et al. 2015; Meijide et al. 2018). Thus, our data indicates that intensive oil palm management leads to high water use rates.

The water use per oil palm in the agroforest was $31 \%$ higher than in the monoculture. This is likely due to the reduction of oil palm stand density by previous thinning in the agroforest, which leads to increases in light, soil water and nutrient availability for the remaining oil palms in the stand. This is also in line with a previous study showing $36 \%$ higher per-palm fruit yield in thinned agroforests than in untreated monocultures (Gérard et al. 2017). The mean individual tree water use in agroforest, on the other hand, was very low (1.1 - $19.8 \mathrm{~kg} \mathrm{day}^{-1}$ ) compared to the water use of the surrounding oil palms. The large difference in tree water use is likely due to the substantial differences in tree size $(4.2 \mathrm{~cm}$ vs $11 \mathrm{~cm})$ and canopy volume $\left(1.1 \mathrm{~m}^{3}\right.$ vs $\left.24 \mathrm{~m}^{3}\right)$. However, tree size also coincides with species identity in our case, so 'ultimate reasons' cannot be disentangled. However, these low absolute rates of the inter-planted trees of relatively small-diameter (DBH range $4.2-11.0 \mathrm{~cm}$ ) compare well to values provided for rubber trees of similarly small diameter in a previous study in the lowlands of Sumatra (Niu et al. 2017). The general observation of high water use per palm also corresponds with data from Amazonian fruit plantations, where it was found that palms consumed 3.5 times more water than trees (Kunert et al. 2015).

Scaled to the stand-level based on our aerial approach, stand transpiration of the oil palm agroforest $\left(1.9 \mathrm{~mm} \mathrm{day}^{-1}\right)$ was $37 \%$ lower than in the oil palm monoculture $(3.0$ $\mathrm{mm}$ day $\left.^{-1}\right)$. The higher per-palm water use in the oil palm agroforest thus did not compensate for the reduction in oil palm stand density when scaled to the stand level. The 3-year old, comparably small inter-planted trees in the agroforestry plot contributed rather little to overall stand transpiration (15\%). The oil palm agroforestry experiment EFForTS-BEE was designed and established to test possibilities of reducing the impact of oil palm cultivation on biodiversity and ecosystem functioning. Oil palm monocultures are associated with ecohydrological problems arising from high transpiration rates and low soil water infiltration capacities (Merten et al. 2016). At the time of study, transpiration rates from the agroforest were substantially reduced in comparison to the commercial monoculture, which may help to alleviate some of the ecohydrological problems. However, restoring the integrity of the local hydrological cycle by means of oil palm agroforestry will also largely depend on whether soil infiltration capacities will increase due to the presence of the inter-planted trees. 


\subsection{Conclusions}

Crown volumes derived from drone-based imagery predicted tree and palm water use quite well. For oil palms, such a scaling variable at the whole-plant level was previously not available. For predicting individual water use, tree crown volumes performed better than the more conventionally used variable stem diameter. In consequence, stand-level transpiration estimates based on crown volumes were associated with reduced uncertainties. We therefore see great potential for future applications of our aerial method in studies scaling plant water use from individual plants to the stand level.

\section{Acknowledgements}

This study was financed by the Deutsche Forschungsgemeinschaft (DFG) in the framework of a collaborative German-Indonesian research project (CRC 990 'EFForTS' project: sub-projects A02 and B11). Watit Khokthong was supported by a PhD-fellowship grant given by the Development and Promotion of Science and Technology Talents Project (DPST) from the Royal Government of Thailand. We would like to thank the Ministry of Research, Technology and Higher Education, Indonesia, for providing the research permit for field work (No. 285/SIP/FRP/E5/Dit.KI/VIII/2016). We would further like to thank our field assistant Erwin Pranata for great support during the field campaigns. Thanks to all 'EFForTS' colleagues and friends in Indonesia, Germany, and around the world. 


\subsection{References (Chapter 2)}

Ådjers, G., Hadengganan, S., Kuusipalo, J., Nuryanto, K., \& Vesa, L. 1995. Enrichment planting of dipterocarps in logged-over secondary forests: effect of width, direction and maintenance method of planting line on selected Shorea species. Forest Ecology and Management 73(1): 259-270.

Aparecido, L. M. T., Miller, G. R., Cahill, A. T., \& Moore, G. W. 2016. Comparison of tree transpiration under wet and dry canopy conditions in a Costa Rican premontane tropical forest. Hydrological Processes 30(26): 5000-5011.

Aumeeruddy, Y. 1994. Local representations and management of agroforests on the periphery of Kerinci Seblat national park, Sumatra, Indonesia. People and Plants working paper 3. The United Nations Educational, Scientific and Cultural Organization, Paris.

Barnes, A. D., Jochum, M., Mumme, S., Haneda, N. F., Farajallah, A., Widarto, T. H., \& Brose, U. 2014. Consequences of tropical land use for multitrophic biodiversity and ecosystem functioning. Nature Communications 5, 5351.

Barnes, C., Balzter, H., Barrett, K., Eddy, J., Milner, S., \& Suárez, J. C. 2017. Individual tree crown delineation from airborne laser scanning for diseased larch forest stands. Remote Sensing 9(3): 1-20.

Bazzaz, F. A. 1979. The physiological ecology of plant succession. Annual Review of Ecology and Systematics 10(1): 351-371.

Bebber, D., Brown, N., Speight, M., Moura-Costa, P., \& Wai, Y. S. 2002. Spatial structure of light and dipterocarp seedling growth in a tropical secondary forest. Forest Ecology and Management 157(1): 65-75.

Birdal, A. C., Avdan, U., \& Türk, T. 2017. Estimating tree heights with images from an unmanned aerial vehicle. Geomatics, Natural Hazards and Risk 8(2): 11441156.

Burgess, S. S., Adams, M. A., Turner, N. C., Beverly, C. R., Ong, C. K., Khan, A. A., \& Bleby, T. M. 2001. An improved heat pulse method to measure low and reverse rates of sap flow in woody plants. Tree Physiology 21(9): 589-598.

Canty, A. and Ripley, B. 2017. boot: Bootstrap R (S-Plus) Functions. R package version 1.3-20.

Čermák, J. 1989. Solar equivalent leaf area: an efficient biometrical parameter of individual leaves, trees and stands. Tree Physiology 5(3): 269-289.

Clough, Y., Krishna, V. V., Corre, M. D., Darras, K., Denmead, L. H., Meijide, A., ... Scheu, S. 2016. Land-use choices follow profitability at the expense of ecological functions in Indonesian smallholder landscapes. Nature Communications 7. 
Colaço, A. F., Trevisan, R. G., Molin, J. P., Rosell-Polo, J. R., \& Escolà, A. 2017. A method to obtain orange crop geometry information using a mobile terrestrial laser scanner and 3D modeling. Remote Sensing 9(8): 10-13.

Davison, A. C. \& Hinkley, D. V. 1997. Bootstrap Methods and Their Applications. Cambridge University Press, Cambridge. ISBN 0-521-57391-2

Delzon, S., Sartore, M., Granier, A., \& Loustau, D. 2004. Radial profiles of sap flow with increasing tree size in maritime pine. Tree Physiology 24(11): 1285-1293.

Díaz-Varela, R. A., de la Rosa, R., León, L., \& Zarco-Tejada, P. J. 2015. HighResolution Airborne UAV Imagery to Assess Olive Tree Crown Parameters Using 3D Photo Reconstruction: Application in Breeding Trials. Remote Sensing 7(4): 4213-4232.

Dierick, D., \& Hölscher, D. 2009. Species-specific tree water use characteristics in reforestation stands in the Philippines. Agricultural and Forest Meteorology 149(8): 1317-1326.

Dislich, C., Keyel, A. C., Salecker, J., Kisel, Y., Meyer, K. M., Auliya, M., ... Faust, H. 2017. A review of the ecosystem functions in oil palm plantations, using forests as a reference system. Biological Reviews 92(3): 1539-1569.

Drescher, J., Rembold, K., Allen, K., Beckschäfer, P., Buchori, D., Clough, Y., ... Scheu, S. 2016. Ecological and socio-economic functions across tropical land use systems after rainforest conversion. Philosophical Transactions of the Royal Society B 371(1694).

Edwards, W. R., Becker, P., \& Cermák, J. 1997. A unified nomenclature for sap flow measurements. Tree Physiology 17(1): 65-67.

Gérard, A., Wollni, M., Hölscher, D., Irawan, B., Sundawati, L., Teuscher, M., \& Kreft, H. 2017. Oil-palm yields in diversified plantations: Initial results from a biodiversity enrichment experiment in Sumatra, Indonesia. Agriculture, Ecosystems \& Environment 240: 253-260.

Granier, A. 1985. Une nouvelle méthode pour la mesure du flux de sève brute dans le tronc des arbres. In Annales des Sciences forestières (Vol. 42, pp. 193-200). EDP Sciences. Available at: https://www.afsjournal.org/articles/forest/pdf/1985/02/AFS_00034312_1985_42_2_ART0004.pdf

Granier, A., Biron, P., \& Lemoine, D. 2000. Water balance, transpiration and canopy conductance in two beech stands. Agricultural and Forest Meteorology 100(4): 291-308.

Hatton, T. J., \& Wu, H. I. 1995. Scaling theory to extrapolate individual tree water use to stand water use. Hydrological Processes 9(5-6): 527-540.

Jarvis, P. G. 1995. Scaling processes and problems. Plant, Cell \& Environment 18(10), 1079-1089. 
Kallimani, C. 2016. Tree crown shape parameter extraction from airborne photogrammetric point cloud. Master Thesis, Wageningen University and Research Centre.

Kume, T., Tsuruta, K., Komatsu, H., Kumagai, T., Higashi, N., Shinohara, Y., \& Otsuki, K. 2010. Effects of sample size on sap flux-based stand-scale transpiration estimates. Tree Physiology 30(1): 129-138.

Kunert, N., Aparecido, L. M. T., Barros, P., \& Higuchi, N. 2015. Modeling potential impacts of planting palms or tree in small holder fruit plantations on ecohydrological processes in the Central Amazon. Forests 6(8): 2530-2544.

Lafarge, T., \& Pateiro-Lopez, B. 2014. Alphashape3d: Implementation of the 3D Alpha-Shape for the Reconstruction of 3D Sets from a Point Cloud. R package version.

Lawrence, D. 2001. Nitrogen and phosphorus enhance growth and luxury consumption of four secondary forest tree species in Borneo. Journal of Tropical Ecology 17(6): 859-869.

Lee, C. T., Wickneswari, R., Clyde, M. M., \& Zakri, A. H. 2002. Maintenance of genetic diversity in Parkia Speciosa in logged-over forests. Journal of Tropical Forest Science 14(2): 163-178.

Lim, Y. S., La, P. H., Park, J. S., Lee, M. H., Pyeon, M. W., \& Kim, J. I. 2015. Calculation of tree height and canopy crown from drone images using segmentation. Journal of the Korean Society of Surveying, Geodesy, Photogrammetry and Cartography 33(6): 605-614.

Lowe, D. G. 2004. Distinctive image features from scale-invariant keypoints. International Journal of Computer Vision 60(2): 91-110.

López-Bernal, Á., Alcántara, E., Testi, L., \& Villalobos, F. J. 2010. Spatial sap flow and xylem anatomical characteristics in olive trees under different irrigation regimes. Tree Physiology 30(12): 1536-1544.

Medhurst, J. L., Battaglia, M., \& Beadle, C. L. 2002. Measured and predicted changes in tree and stand water use following high-intensity thinning of an 8-year-old Eucalyptus nitens plantation. Tree Physiology 22(11): 775-784.

Mei, T., Fang, D., Röll, A., Niu, F., Hendrayanto, \& Hölscher, D. 2016. Water use patterns of four tropical bamboo species assessed with sap flux measurements. Frontiers in Plant Science 6.

Meijide, A., Badu, C. S., Moyano, F., Tiralla, N., Gunawan, D., \& Knohl, A. 2018. Impact of forest conversion to oil palm and rubber plantations on microclimate and the role of the 2015 ENSO event. Agricultural and Forest Meteorology 252: 208-219.

Merten, J., Röll, A., Guillaume, T., Meijide, A., Tarigan, S., Agusta, H., ... Hölscher, D. 2016. Water scarcity and oil palm expansion: social views and environmental processes. Ecology and Society 21(2). 
Moore, G. W., Orozco, G., Aparecido, L. M. T., \& Miller, G. R. 2017. Upscaling transpiration in diverse forests: Insights from a tropical premontane site. Ecohydrology 11.

Niu, F., Röll, A., Hardanto, A., Meijide, A., Köhler, M., \& Hölscher, D. 2015. Oil palm water use: calibration of a sap flux method and a field measurement scheme. Tree Physiology 35(5): 563-573.

Niu, F., Röll, A., Meijide, A., Hendrayanto, \& Hölscher, D. 2017. Rubber tree transpiration in the lowlands of Sumatra. Ecohydrology 10(7).

Oren, R., Phillips, N., Ewers, B. E., Pataki, D. E., \& Megonigal, J. P. 1999. Sap-fluxscaled transpiration responses to light, vapor pressure deficit, and leaf area reduction in a flooded Taxodium distichum forest. Tree Physiology 19(6): 337347.

Orwa, C., Mutua, A., Kindt, R., Jamnadass, R., and Simons, A. 2009. Agroforest tree database: a tree reference and selection guide version 4.0. Available at: http://www.worldagroforestry.org/output/agroforestree-database (Accessed June 11, 2018).

Oishi, A. C., Oren, R., \& Stoy, P. C. 2008. Estimating components of forest evapotranspiration: a footprint approach for scaling sap flux measurements. Agricultural and Forest Meteorology 148(11): 1719-1732.

Panagiotidis, D., Abdollahnejad, A., Surový, P., \& Chiteculo, V. 2016. Determining tree height and crown diameter from high-resolution UAV imagery. International Journal of Remote Sensing 38(8-10): 2392-2410.

Pateiro-López, B., \& Rodriguez-Casal, A. 2010. Generalizing the convex hull of a sample: the R package alphahull. Journal of Statistical Software 34(5): 1-28.

Peters, R. L., Fonti, P., Frank, D. C., Poyatos, R., Pappas, C., Kahmen, A., ... Steppe, K. 2018. Quantification of uncertainties in conifer sap flow measured with the thermal dissipation method. New Phytologist 219(4): 1283-1299.

Poorter, L., Bongers, L., \& Bongers, F. 2006. Architecture of 54 moist-forest tree species: traits, trade-Offs, and functional groups. Ecology 87(5): 1289-1301.

Pretzsch, H., Biber, P., Uhl, E., Dahlhausen, J., Rötzer, T., Caldentey, J., ... Pauleit, S. 2015. Crown size and growing space requirement of common tree species in urban centres, parks, and forests. Urban Forestry and Urban Greening 14(3): 466-479.

Preuhsler, T. 1979. Ertragskundliche Merkmale oberbayerischer BergmischwaldVerjüngungsbestände auf kalkalpinen Standorten im Forstamt Kreuth. Forstwissenschaftliches Centralblatt 100(1): 313-345.

R Development Core Team. 2016. R: A language and environment for statistical computing. R Foundation for Statistical Computing, Vienna, Austria. 
Röll, A., Niu, F., Meijide, A., Hardanto, A., Hendrayanto, Knohl, A., \& Hölscher, D. 2015. Transpiration in an oil palm landscape: effects of palm age. Biogeosciences 12(19): 5619-5633.

Schiller, G., Cohen, S., Ungar, E. D., Moshe, Y., \& Herr, N. 2007. Estimating water use of Sclerophyllous species under East-Mediterranean climate: III. Tabor oak forest sap flow distribution and transpiration. Forest Ecology and Management 238(1): 147-155.

Silva, C. A., Crookston, N. L., Hudak, A. T., Vierling, L. A., Klauberg, C., \& Silva, M. C. A. 2017. Package 'rLiDAR.'

Tao, S., Wu, F., Guo, Q., Wang, Y., Li, W., Xue, B., ... Fang, J. 2015. Segmenting tree crowns from terrestrial and mobile LiDAR data by exploring ecological theories. ISPRS Journal of Photogrammetry and Remote Sensing 110: 66-76.

Teuscher, M., Gérard, A., Brose, U., Buchori, D., Clough, Y., Ehbrecht, M., .. Kreft, H. 2016. Experimental biodiversity enrichment in oil-palm-dominated landscapes in Indonesia. Frontiers in Plant Science 7.

Thiel, C., \& Schmullius, C. 2016. Derivation of forest parameters from stereographic uav data a comparison with airborne lidar data. In Living Planet Symposium (Vol. 740, p. 189).

Torres-Sánchez, J., López-Granados, F., Serrano, N., Arquero, O., \& Peña, J. M. 2015. High-Throughput 3-D monitoring of agricultural-tree plantations with unmanned aerial vehicle (UAV) technology. PLOS ONE 10(6).

Trochta, J., Kruček, M., Vrška, T., \& Kraâl, K. 2017. 3D Forest: An application for descriptions of three-dimensional forest structures using terrestrial LiDAR. PLoS ONE 12(5): 1-17.

Vauhkonen, J., Næsset, E., \& Gobakken, T. 2014. Deriving airborne laser scanning based computational canopy volume for forest biomass and allometry studies. ISPRS Journal of Photogrammetry and Remote Sensing 96: 57-66.

Vertessy, R. A., Benyon, R. G., O’Sullivan, S. K., \& Gribben, P. R. 1995. Relationships between stem diameter, sapwood area, leaf area and transpiration in a young mountain ash forest. Tree Physiology 15(9): 559-567.

Vivoni, E. R., Rango, A., Anderson, C. A., Pierini, N. A., Schreiner-McGraw, A. P., Saripalli, S., \& Laliberte, A. S. 2014. Ecohydrology with unmanned aerial vehicles. Ecosphere 5(10): 1-14.

Wang, H., Xing, L., Ma, L., \& Sun, P. 2006. Scaling-up method for stand water consumption of Quercus variabilis water conservation forest. Frontiers of Forestry in China 1(3): 292-297.

Westoby, M. J., Brasington, J., Glasser, N. F., Hambrey, M. J., \& Reynolds, J. M. 2012. 'Structure-from-Motion' photogrammetry: A low-cost, effective tool for geoscience applications. Geomorphology 179 (Supplement C): 300-314. 
Wullschleger, S. D., Meinzer, F. C., \& Vertessy, R. A. 1998. A review of whole-plant water use studies in tree. Tree Physiology 18(8-9): 499-512.

Yue, G., Zhao, H., Zhang, T., Zhao, X., Niu, L., \& Drake, S. 2008. Evaluation of water use of Caragana microphylla with the stem heat-balance method in Horqin Sandy Land, Inner Mongolia, China. Agricultural and Forest Meteorology 148(11): 1668-1678. 


\subsection{Appendix (Chapter 2)}

Appendix Table 1. Drone-derived crown metrics for oil palm and four studied tree species. Tree height as derived from the canopy height model and diameters as measured at breast height are further provided. Means \pm standard deviations of the palms and trees where sap flux measurements were performed, with sample size $\mathrm{n}=4$ for all groups. Crown volume was derived using convex hull and alpha shape algorithm for oil palms and trees, respectively.

\begin{tabular}{|c|c|c|c|c|c|c|c|c|}
\hline & $\begin{array}{l}\text { DBH } \\
(\mathrm{cm})\end{array}$ & $\begin{array}{c}\text { Height } \\
(\mathrm{m})\end{array}$ & $\begin{array}{c}\text { Crown } \\
\text { length } \\
(\mathrm{m})\end{array}$ & $\begin{array}{l}\text { Crown } \\
\text { diameter } \\
(\mathrm{m})\end{array}$ & $\begin{array}{c}\text { Crown } \\
\text { volume } \\
\left(\mathrm{m}^{3}\right)\end{array}$ & $\begin{array}{c}\text { Crown } \\
\text { projection area } \\
\left(\mathrm{m}^{2}\right)\end{array}$ & $\begin{array}{c}\text { Crown } \\
\text { surface } \\
\text { area }\left(\mathrm{m}^{2}\right)\end{array}$ & $\begin{array}{c}\text { Daily water } \\
\text { use } \\
\left(\mathrm{kg} \mathrm{day}^{-1}\right)\end{array}$ \\
\hline $\begin{array}{l}\text { Oil palms } \\
\text { (agroforest) }\end{array}$ & $90.1 \pm 8.6$ & $6.8 \pm 0.2$ & $4.7 \pm 0.2$ & $11.3 \pm 1.1$ & $665.7 \pm 162.8$ & $92.3 \pm 14.4$ & $392.2 \pm 65.0$ & $223.0 \pm 20.0$ \\
\hline $\begin{array}{c}\text { Oil palms } \\
\text { (monoculture) }\end{array}$ & $85.2 \pm 7.3$ & $5.9 \pm 0.6$ & $3.8 \pm 0.3$ & $10.2 \pm 0.8$ & $371.1 \pm 33.2$ & $77.5 \pm 12.0$ & $274.0 \pm 18.4$ & $168.9 \pm 15.4$ \\
\hline \multicolumn{9}{|l|}{ Trees } \\
\hline $\begin{array}{l}\text { Archidendron } \\
\text { pauciflorum }\end{array}$ & $8.8 \pm 1.2$ & $7.9 \pm 1.0$ & $5.5 \pm 1.2$ & $4.2 \pm 0.6$ & $15.5 \pm 5.5$ & $12.0 \pm 3.2$ & $65.2 \pm 21.5$ & $16.2 \pm 2.9$ \\
\hline $\begin{array}{c}\text { Parkia } \\
\text { speciosa }\end{array}$ & $7.2 \pm 1.6$ & $7.5 \pm 1.0$ & $4.0 \pm 0.8$ & $4.0 \pm 0.9$ & $6.6 \pm 3.4$ & $8.8 \pm 3.5$ & $52.6 \pm 28.3$ & $6.6 \pm 4.3$ \\
\hline $\begin{array}{l}\text { Peronema } \\
\text { canescens }\end{array}$ & $9.2 \pm 1.1$ & $7.1 \pm 0.9$ & $4.9 \pm 0.6$ & $3.8 \pm 0.3$ & $9.9 \pm 2.6$ & $9.6 \pm 1.3$ & $56.5 \pm 8.1$ & $15.0 \pm 6.3$ \\
\hline $\begin{array}{l}\text { Shorea } \\
\text { leprosula }\end{array}$ & $5.1 \pm 0.6$ & $1.9 \pm 0.3$ & $1.7 \pm 0.3$ & $1.8 \pm 1.0$ & $2.2 \pm 1.0$ & $21.6 \pm 5.9$ & $2.4 \pm 1.1$ & $4.2 \pm 0.6$ \\
\hline
\end{tabular}


Appendix Table 2. Equipment and flight details.

\begin{tabular}{ll}
\hline Camera & Nikon D5100 \\
Drone & MikroKopter OktoXL \\
Flight altitude & $39 \mathrm{~m}$ \\
Image overlap & $70 \%$ \\
Number of images & $995 \mathrm{ha}^{-1}$ \\
Focal length & $35 \mathrm{~mm}^{-2}$ \\
Ground resolution & $5 \mathrm{~mm} / \mathrm{pixel}^{-1}$ \\
Point density & $3 \mathrm{points} \mathrm{cm}^{-2}$ \\
\hline
\end{tabular}

Appendix Figure 1. Validation of drone-derived canopy heights and widths with ground reference measurements ( $\mathrm{n}=99$ trees and palms).
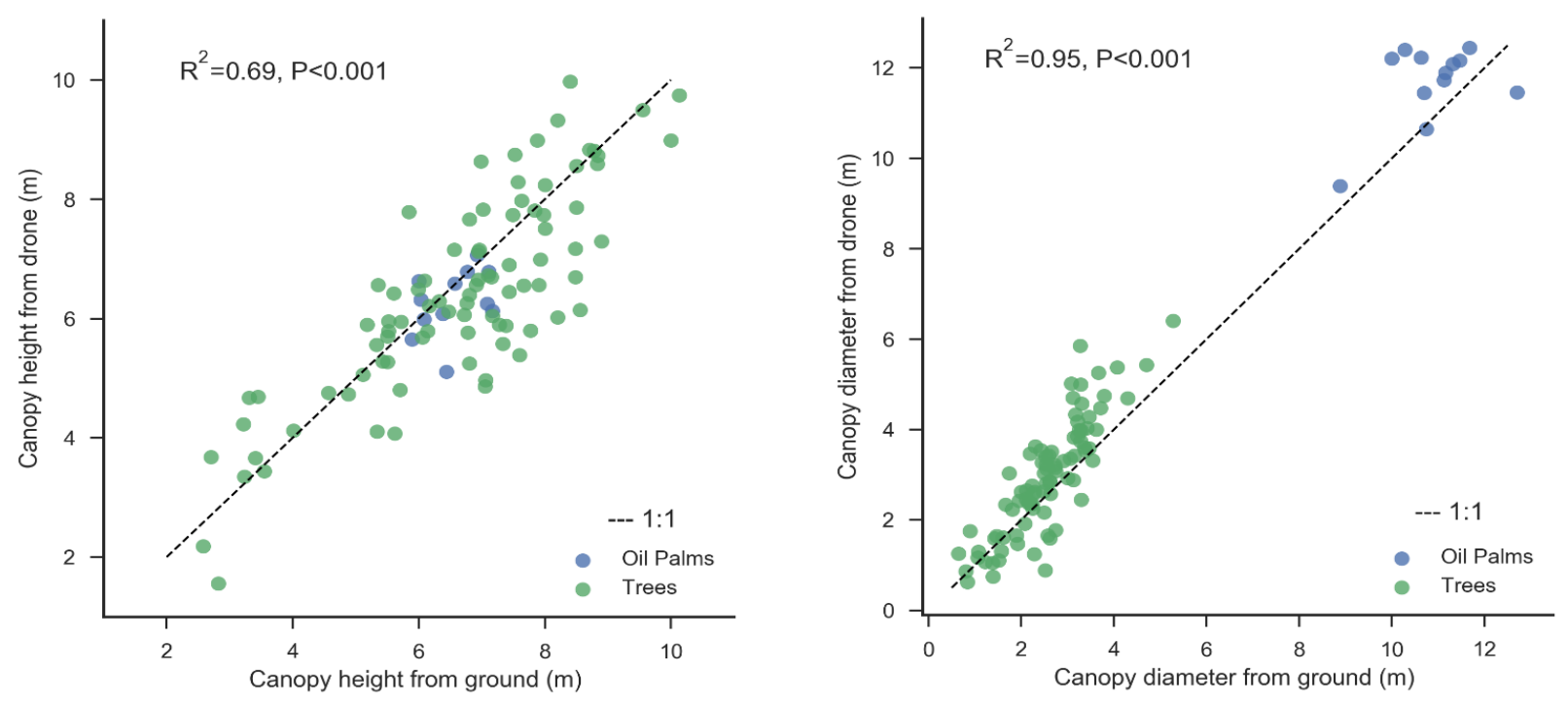
Appendix Figure 2. 3D visualization of oil palm and tree (four tree species) crowns derived from different crown volume models (convex hull and different alpha levels).

Oil palm (Elaeis guineensis Jacq.)

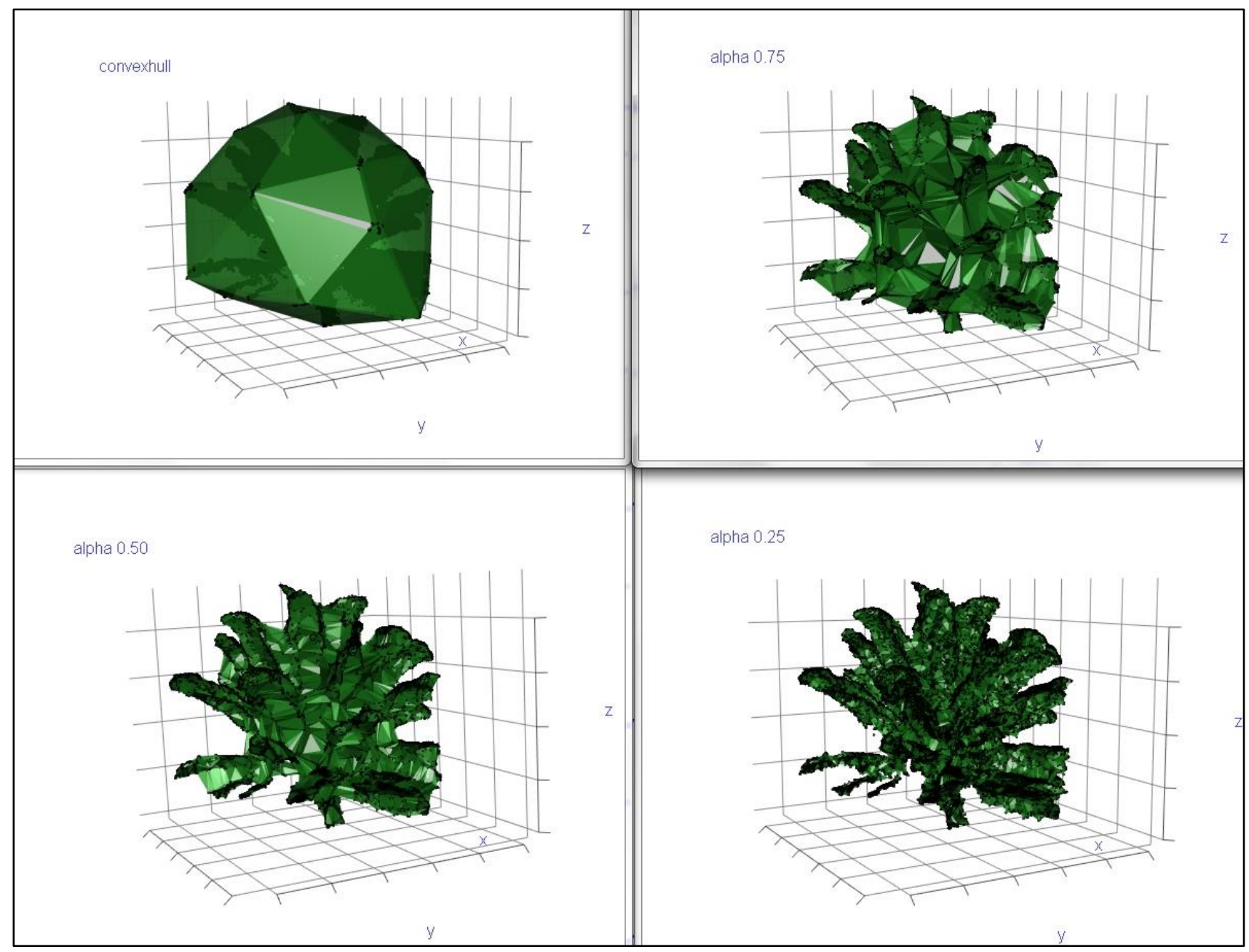


Archidendron pauciflorum

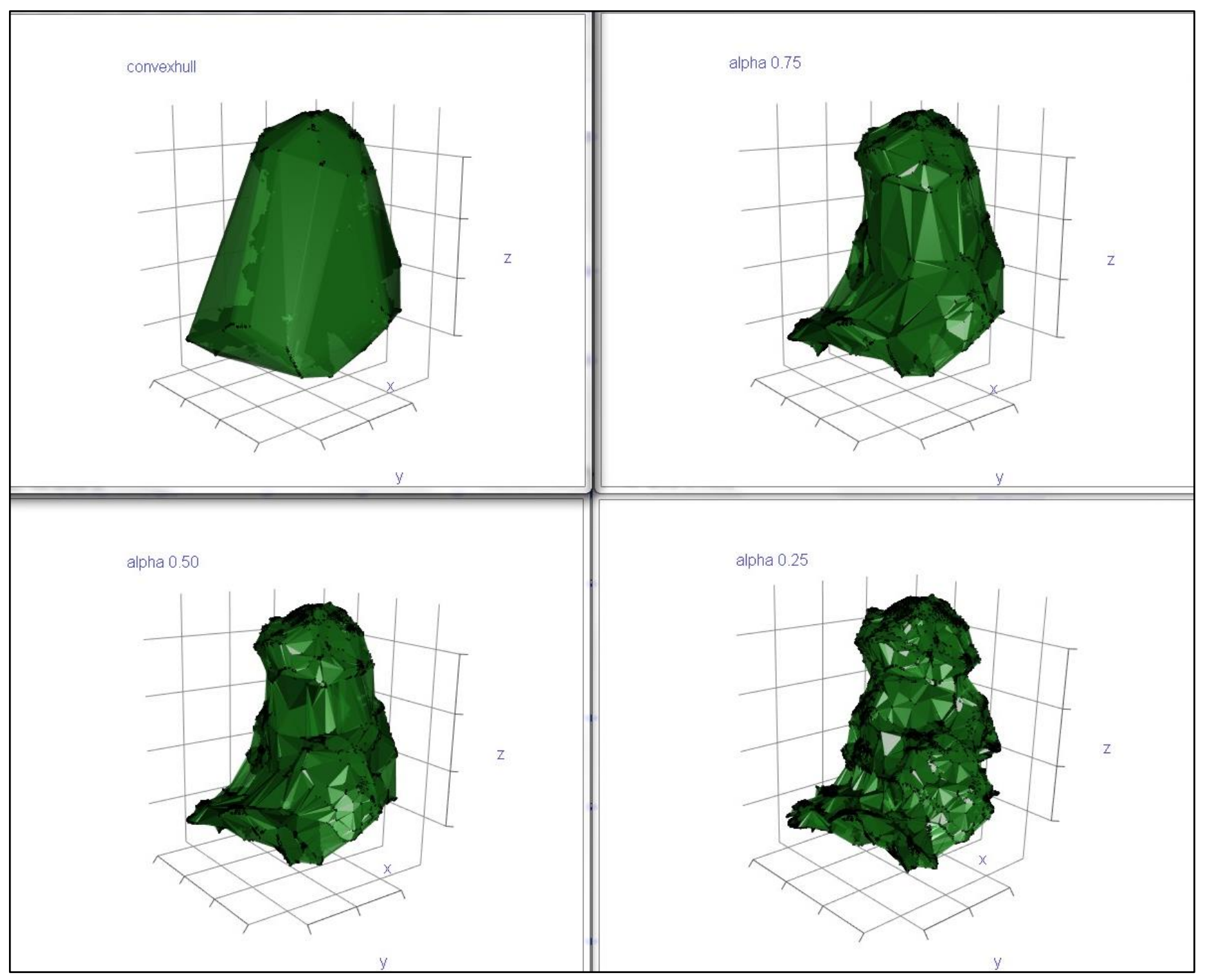


Parkia speciosa

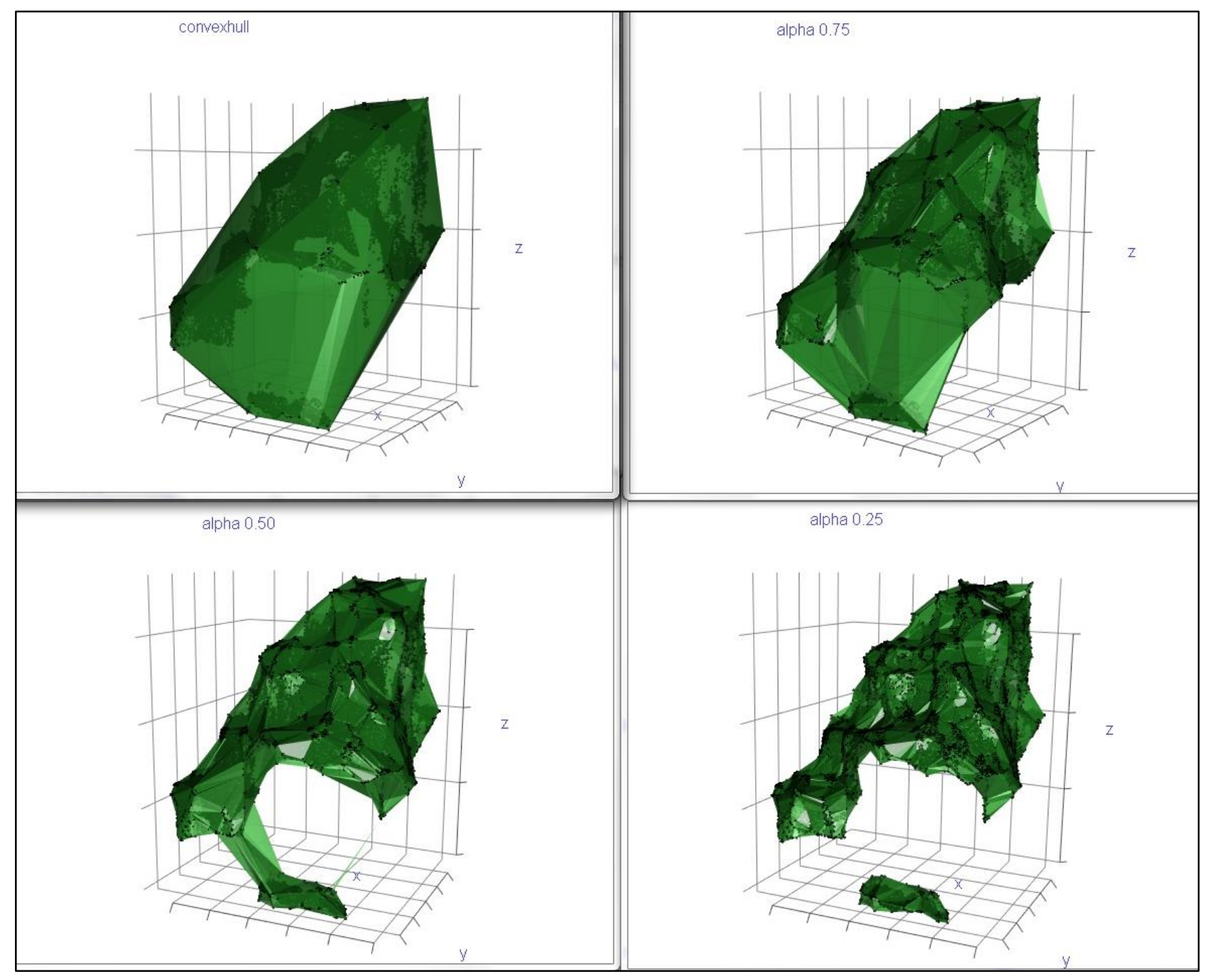




$$
\begin{array}{ll}
0 \\
1
\end{array}
$$


Shorea leprosula

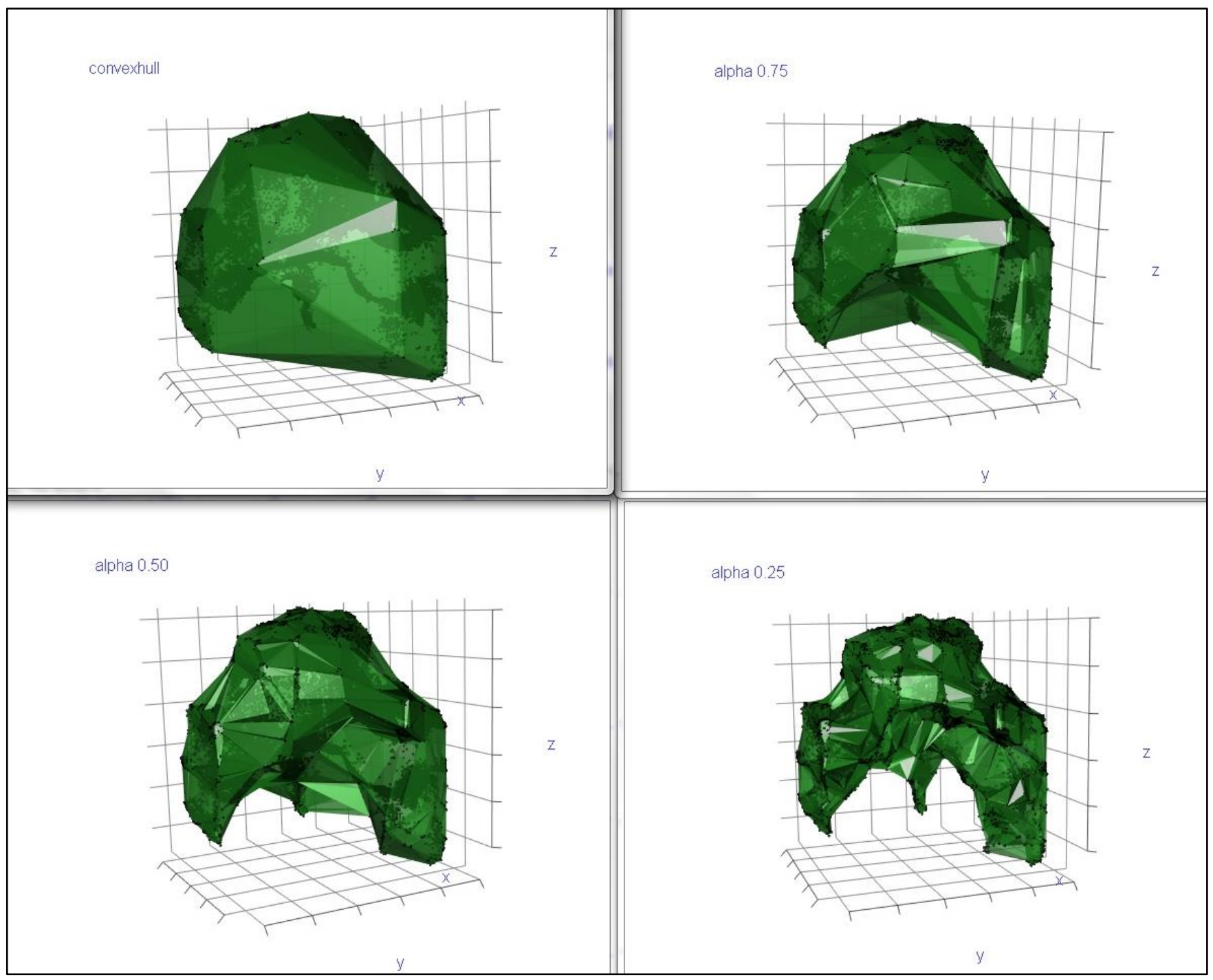


Appendix Figure 3. Daily water use across trees and oil palms versus crown volumes alpha shape 0.75 . The quality criterion of normality and homeoscedascity was however violated (Shapiro Wilk test, $\mathrm{P}=0.000042$ ).

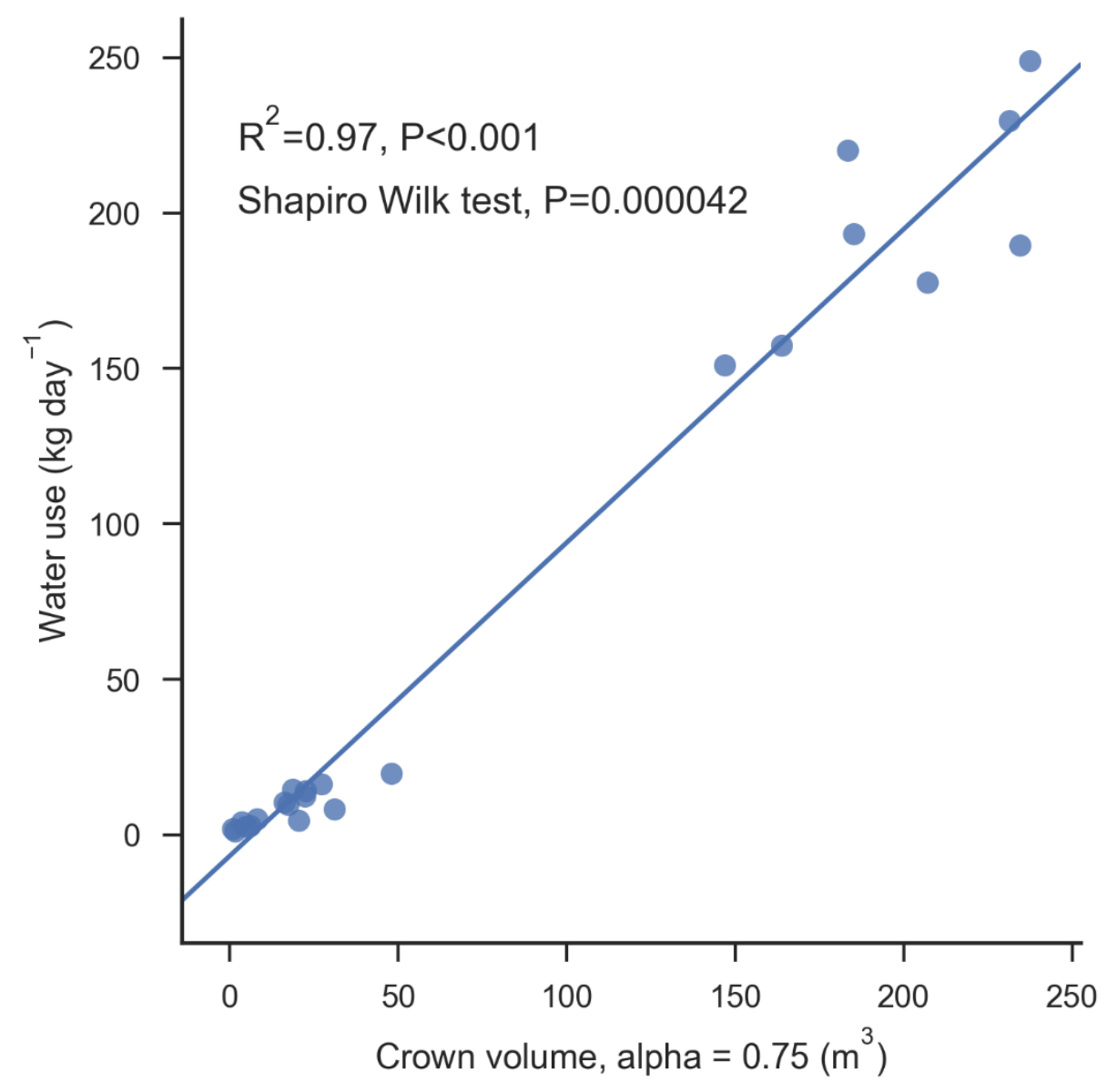




\subsection{A full methodology description of drone image acquisition and crown metric processing (Chapter 2)}

\subsubsection{Flight plan}

The octocopter drone (MikroKopter OktoXL; Mikrokopter, Germany), with a payload capacity of $5.5 \mathrm{~kg}$, carried a high-grade commercial camera and battery compartment. The camera (NIKON DSLR D5100, lens AF-S NIKKOR 18-55 mm) was mounted on a gimbal stabilized platform (MK HiSight SLR1; Mikrokopter Inc., Germany), which can balance the camera pose both in horizontal and vertical direction for taking RGB images during the missions. I set image quality at a resolution of $4928 \times 3264$ pixels with white balance and focus in automatic mode.

Before flying, the mission plan was set up using Mikrokopter-Tool (version 2.14b). In general, the waypoint parameters were set by fixed parameters; 35 meter flight altitude, 2 meter per second flying speed. The camera triggering mechanism was set at $35 \mathrm{~mm}$ focal length, capture rate of one photo per second to achieve image forward and side overlap of 70 percent. I designed two types of mission plans (circular and grid pathway) with two different camera directions (nadir angle and oblique angle from nadir $45^{\circ}$ ) in order to create a perfect 3D model. For the circular pathway, a difference of 10-m radius between the two circular pathways (radius sizes from 35 to $40 \mathrm{~m}$ ) was established to obtain a sufficient number of photos for matching in the oblique direction (pointing $45^{\circ}$ to plot center). The grid pathway covered the entire plot and also extended beyond the plot at least two plantation rows of oil palm (around $10 \mathrm{~m}$ from plot boundary). In each plot, circular and grid flying were conducted around midday and with the same mission. Before take-off, all flight parameters were transferred by Bluetooth signal to the drone mainboard and the GPS position of drone was spatially detected by at least 5 satellites during the mission. Autopilot mode facilitated the mission plan after take-off and camera began automatically taking photos.

\subsubsection{Point clouds reconstruction and drone-related outputs}

After landing, the spatial location and time of flight path (GPX file) were recorded in the onboard SD card, and images were downloaded. All images were then georeferenced by GPX file with GPX Viewer software (version 0.66) and exported as compatible photo-log files before processing in Agisoft Photoscan Professional (version 1.2.6). The drone images were aligned and constructed in $3 \mathrm{D}$ point clouds with four main workflows (image alignment, build dense point cloud, generation of digital 
elevation model (DEM), and orthomosaic generation). At the step of image alignment, high quality image settings were used, while ground-control points (GCPs) printed at 8-Bit barcodes were used to determine the overall positional accuracy. Then, 3D point clouds were generated within multiple images and orthophotos were produced using structure-from-motion (SfM) techniques. The final RGB point clouds were possible to export as a Log ASCII Standard (LAS) file for visualization and interpretation with RGB orthophoto. The output RGB orthomosaic shows merged image sets for each study site, which can easily delineate tree crown boundary through visual interpretation and tree coordinates by drawing the crown polygon in Qgis software (version 2.14). Moreover, one must geo-register the point clouds to orthophoto as reference image. I co-registered SfM point clouds at each GCP in Cloud Compare software (version 2.6.1).

Classifying terrain is compulsory to generate digital terrain model (DTM). This algorithm can run with SfM point clouds in "classify ground points" tool in Agisoft Photoscan. There are three parameters to classify ground and non-ground points; maximum angle, maximum distance, and cell size into. All ground points were generated into a DTM raster, which only shows elevation from the ground terrain.

\subsubsection{Tree crown parameter estimations}

The CHM was implemented in SAGA GIS software (version 2.0.6) by overlay of DEM with DTM with a smooth filter applied. The individual canopy height of trees (the highest point from local maxima) and meristem height of oil palms (lowest point at meristem part from local minima) were obtained from CHM overlaid by the individual crown polygons in SAGA GIS software. The tree canopy heights and oil palm meristem heights derived from the CHM were further compared to reference height measurements from the ground using a measurement pole.

After export of point cloud data in LAS format, it is necessary to delete aggregated points and noises automatically and manually in Cloud Compare software. To extract single trees and oil palms from the 3D point cloud, the PolyClip function can be used for individual tree segmentation by crown polygons in Fusion software (version 3.6). Crown variables of each individual were obtained using the Tree Measurement tool in the same software, which is capable of measuring 3D crown projection. Measurements including crown length (vertical projection) and crown diameter (horizonal projection) of target tree and oil palm were conducted. The measured tree crown variables from 
ground-based measurements were conducted by the vertical sighting method (Pretzsch et al. 2015). However, the certain reference of crown volume was not conducted in the field.

To estimate crown volume of trees and oil palms from point cloud data, the trunk parts must be removed manually in Cloud Compare software. Then, the center part of SfM point clouds must be moved from the original xyz coordinate axis (in UTM) to the zero xyz axis $(x=0, y=0, z=0)$, but this shifting does not affect the original spatial information of point clouds. Finally, the main canopy portion of individual trees and oil palms were interpolated in $\mathrm{R}$ version 3.4.3 (R Development Core team, 2016). I estimated crown volume $\left(\mathrm{m}^{3}\right)$ using a triangulation algorithm of 3D point data with the varying point density approach and illustrated crown figures by Alphashape3D (Lafarge and Pateiro-Lopez 2017). This approach was adapted from LiDAR point clouds processing and is possible to execute with high density SfM point clouds. The closer the alpha parameter to 1.0 is the more likely the optimizing shape equally to the convex hulls. Moreover, I calculated crown volumes by reducing alpha value to 0.75 , 0.50 and 0.25 , respectively (Colaço et al. 2017). If the alpha value reduces, it optimizes the volume estimation by forming a more tight shape around the original points (Vauhkonen et al. 2016). To select which alpha value presented the highest correlation with tree water use, the coefficient of determination of linear regression $\left(\mathrm{R}^{2}\right)$ was determined and compared among crown volumes from different alpha values and convex hulls. Moreover, 2D Convex hulls of individual point clouds were calculated to measure the crown planar area in R, library rLiDAR, function chullLiDAR2D (Silva et al. 2017). 


\subsubsection{References (Chapter 2.8)}

Colaço, A. F., Trevisan, R. G., Molin, J. P., Rosell-Polo, J. R., \& Escolà, A. 2017. A method to obtain orange crop geometry information using a mobile terrestrial laser scanner and 3D modeling. Remote Sensing 9 (8): 10-13.

Lafarge, T., \& Pateiro-Lopez, B. 2014. Alphashape3d: implementation of the 3D alphashape for the reconstruction of $3 \mathrm{D}$ sets from a point cloud. $\mathrm{R}$ package version 1.1 .

Pretzsch, H., Biber, P., Uhl, E., Dahlhausen, J., Rötzer, T., Caldentey, J., Koike, T., ... Pauleit, S. 2015. Crown size and growing space requirement of common tree species in urban centres, parks, and forests. Urban Forestry and Urban Greening 14 (3): 466-479.

R Development Core Team. 2016. R: a language and environment for statistical computing. R Foundation for Statistical Computing, Vienna, Austria.

Silva, C. A., Crookston, N. L., Hudak, A. T., Vierling, L. A., Klauberg, C., \& Silva, M. C. A. 2017. Package 'rLiDAR.'

Vauhkonen, J., Holopainen, M., Kankare, V., Vastaranta, M., \& Viitala, R. 2016. Geometrically explicit description of forest canopy based on 3D triangulations of airborne laser scanning data. Remote Sensing of Environment 173: 248-257. 


\section{Chapter 3}

\section{Drone-based assessment of canopy cover for analyzing tree mortality in an oil palm agroforest}

Watit Khokthong ${ }^{1}$, Delphine Clara Zemp ${ }^{2}$, Bambang Irawan $^{3}$, Leti Sundawati ${ }^{4}$, Holger Kreft ${ }^{2,5}$, Dirk Hölscher ${ }^{1,5}$

${ }^{1}$ Tropical Silviculture and Forest Ecology, University of Goettingen, Goettingen, Germany

${ }^{2}$ Biodiversity, Macroecology and Biogeography, University of Goettingen, Goettingen, Germany

${ }^{3}$ Faculty of Forestry, University of Jambi, Jambi, Indonesia

${ }^{4}$ Faculty of Forestry, Bogor Agricultural University, Bogor, Indonesia

${ }^{5}$ Centre of Biodiversity and Sustainable Land Use, University of Goettingen, Goettingen, Germany

Correspondence: Watit Khokthong, Email: watit.khokthong@forst.uni-goettingen.de

Accepted manuscript in Frontiers in Forests and Global Change (2019).

doi: 10.3389/ffgc.2019.00012 


\begin{abstract}
Oil palm monocultures are highly productive, but there are widespread negative impacts on biodiversity and ecosystem functions. Some of these negative impacts might be mitigated by mixed-species tree interplanting to create agroforestry systems, but there is little experience with the performance of trees planted in oil palm plantations. We studied a biodiversity enrichment experiment in the lowlands of Sumatra that was established in a six to twelve year-old oil palm plantation by planting six tree species in different mixtures on 48 plots. Three years after tree planting, canopy cover was assessed by drone-based photogrammetry using the structure-from-motion technique. Drone-derived canopy cover estimates were highly correlated with traditional groundbased hemispherical photography along the equality line, indicating the usefulness and comparability of the approach. Canopy cover was further partitioned between oil palm and tree canopies. Thinning of oil palms before tree planting created a more open and heterogeneous canopy cover. Oil palm canopy cover was then extracted at the level of oil palms and individual trees and combined with ground-based mortality assessment for all 3819 planted trees. For three tree species (Archidendron pauciflorum, Durio zibethinus, Shorea leprosula), the probability of mortality during the year of the study was dependent on the amount of oil palm canopy cover. We regard the drone-based method for deriving and partitioning spatially explicit information as a promising way for many questions addressing canopy cover in ecological applications and the management of agroforestry systems.
\end{abstract}

Keywords: agroforestry, photogrammetry, structure from motion, SfM, Sumatra, Indonesia, unmanned aerial vehicle, UAV 


\subsection{Introduction}

The area of oil palm (Elaeis guineensis) cultivation has strongly increased over the past decades (FAO 2016; Vijay et al. 2016) and its cultivation generates high economic returns (Rist et al. 2010; Clough et al. 2016; Euler et al. 2016). In conventional plantations, oil palm is usually grown in monocultures (Azhar et al. 2017). In comparison with other land use systems, and in particular with forests, such plantations present severely reduced biodiversity and impaired ecosystem functions (Foster et al. 2011; Barnes et al. 2014; Drescher et al. 2016; Dislich et al. 2017). Agroforestry systems that combine agricultural crops and trees often harbor higher biodiversity and provide more diverse ecosystem functions than mono-agricultural land uses (Bhagwat et al. 2008; Jose 2012; Tscharntke et al. 2012; Barrios et al. 2017; Ashraf et al. 2018). Including agroforestry zones and also forest reserves in oil palm dominated landscapes has been proposed as a way to better balance economic and ecological needs (Koh et al. 2009). However, there is very little experience with the management of oil palm agroforestry.

Planting multiple native tree species into existing oil palm plantations may be one option for the establishment of such agroforestry systems (Teuscher et al. 2016). Mature oil palms possess a height advantage and would likely be less affected by competition from planted trees (Gérard et al. 2017). The trees thus need to cope with the light conditions beneath the oil palm canopy, which, however, could be influenced by thinning. In evaluation of planted tree performance, mortality is a central variable, but light requirements differ between tree species (Davidson et al. 2002). A heterogeneous oil palm canopy cover may offer varied light conditions that may meet the light requirements of different species. So far, knowledge on species-specific site matching under such conditions is limited.

Canopy cover of oil palms is usually strongly related to the height of the oil palm stand and this has been used to predict aboveground carbon (Nunes et al. 2017) and animal abundance of the oil palm plantation (Konopik et al. 2014). In the context of an oil palm agroforest, dense canopy cover of oil palm could reduce the light intensity received by understory trees passing through canopy layers (Prastyaningsih and Azwin 2017). For an adequate assessment of oil palm canopy cover, ground-based methods such as a Cajanus sighting tube and line canopy edges intersect by tape-measures could be used (Jennings et al. 1999; Korhonen et al. 2006; Ma et al. 2017). Other well-established methods include measurements of leaf area index e.g. with instruments like the LAI2000 plant canopy analyzer (Awal and Wan Ishak 2008), and hemispherical photography with fish-eye lens camera (Awal et al. 2010; Mailly 2017). However, these ground-based methods are usually time consuming or impractical over the large area of an oil palm plantation.

Drone-based surveys of canopy cover offer new opportunities and are capable of producing results from multi-plot assessment (Shin et al. 2018). Sensors may include light detection and ranging (LiDAR) techniques (Guo et al. 2017), or multispectral 
imaging capturing red, green and blue (RGB) spectral information (Nevalainen et al. 2017). RGB images are useful to estimate vegetation canopy cover from a canopy height model (CHM) (Zhang et al. 2016), and for image classification through a photogrammetric approach using the structure-from-motion (SfM) technique (TorresSánchez et al. 2014; Chianucci et al. 2016; Banu et al. 2017; Ivosevic et al. 2017). Based on the segmentation method, using a normalized difference vegetation index and CHM, a $10 \mathrm{~m}$ resolution of canopy cover map could be produced (Shin et al. 2018). LiDAR processing workflows, in conjunction with SfM point clouds derived from RGB images, should be sufficient to generate a canopy cover map (Wallace et al. 2016).

The present study was conducted in an experimental oil palm agroforest in the lowlands of Sumatra, Indonesia, where oil palm monocultures have expanded rapidly over the last decades (Drescher et al. 2016). Within such a monocultural landscape, a biodiversity enrichment experiment (EFForTS-BEE) was established in 2013 by planting six native tree species within six to twelve-year-old oil palm stands, usually after thinning oil palms in the planting area (Teuscher et al. 2016). In the first years of the experiment, initial results of the thinning oil palm experiment showed that the net oil palm yield at plot level did not change or even increased, and that tree planting did not impair oil palm yield (Gérard et al. 2017). In contrast, tree growth was negatively affected by the proximity to oil palms (Zemp et al. in revision). In 2016, we applied a drone-based photogrammetric approach to the study area, using a low-flying octocopter equipped with an RGB camera, in order to analyze the canopy cover. The main objectives were (1) to generate high resolution maps of canopy cover, (2) to partition the canopy into oil palm and tree components, and (3) to apply the methodology to compare oil palm canopy conditions of thinned and non-thinned plots as well as to analyze the effect of oil palm canopy cover on tree mortality. We expect that such a drone-based approach offers a new way of analyzing the canopy cover in agroforestry systems.

\subsection{Methods}

\subsubsection{Study site}

The study was conducted in the lowlands of Jambi in Sumatra, Indonesia on the land of the company PT. Humusindo Makmur Sejati (01.95 ${ }^{\circ} \mathrm{S}$ and $\left.103.25{ }^{\circ} \mathrm{E}\right)$. The mean annual precipitation in the region is $2235 \mathrm{~mm} /$ annum and the mean annual temperature is $26.7^{\circ} \mathrm{C}$ (Drescher et al. 2016). The main soil type is loamy Acrisol (Allen et al. 2015) and the average altitude at the study site is $47 \mathrm{~m}$ a.s.l. (Teuscher et al. 2016). In 2013, the biodiversity enrichment experiment (EFForTS-BEE) was established in six to twelve-years-old oil palm plantations with a mean palm density of 143 palms per hectare (Teuscher et al. 2016). The experiment comprises 56 plots distributed over 150 hectares. Trees were planted in 48 plots of variable sizes $\left(25,100,400,1600 \mathrm{~m}^{2}\right)$. Before planting, oil palm stand density was thinned by $40 \%$, excluding plots of $25 \mathrm{~m}^{2}$ area that remained unthinned (Teuscher et al. 2016). Six native multi-purpose tree 
species were planted: Archidendron pauciflorum, Durio zibethinus, Dyera polyphylla, Parkia speciosa, Peronema canescens and Shorea leprosula (Table 3.1). Trees were planted at a distance of $2 \mathrm{~m}$ by $2 \mathrm{~m}$, and in different biodiversity levels of one, two, three and six species per plot (Appendix Table 1). At the time of the study, the average height of oil palm meristems was $536 \mathrm{~cm}$, and the average tree height per species ranged from $88 \mathrm{~cm}$ in D. polyphylla to $403 \mathrm{~cm}$ in $P$. canescens.

Table 3.1. Planted tree species and some main ecological characteristics and purpose of uses.

\begin{tabular}{|c|c|c|c|c|}
\hline Tree species & Family & $\begin{array}{l}\text { Name in } \\
\text { Bahasa } \\
\text { Indonesia }\end{array}$ & Main use & $\begin{array}{l}\text { Light characteristics } \\
\text { at early life stage }\end{array}$ \\
\hline $\begin{array}{l}\text { Archidendron } \\
\text { pauciflorum }\end{array}$ & Fabaceae & Jengkol & $\begin{array}{l}\text { Food, edible } \\
\text { seed }\end{array}$ & $\begin{array}{l}\text { Light demanding } \\
\text { (Aumeeruddy 1994) }\end{array}$ \\
\hline Durio zibethinus & Malvaceae & Durian & $\begin{array}{l}\text { Food, edible } \\
\text { fruit }\end{array}$ & $\begin{array}{l}\text { Shade tolerant } \\
\text { (Harja et al. 2012; } \\
\text { Nguyen et al. 2014) }\end{array}$ \\
\hline Dyera polyphylla & Apocynaceae & Jelutung & $\begin{array}{l}\text { Latex and } \\
\text { wood }\end{array}$ & $\begin{array}{l}\text { Pioneer, light } \\
\text { demanding (Graham } \\
\text { et al. 2017) }\end{array}$ \\
\hline Parkia speciosa & Fabaceae & Petai & $\begin{array}{l}\text { Food, edible } \\
\text { seed }\end{array}$ & $\begin{array}{l}\text { Pioneer, light } \\
\text { demanding (Lee et } \\
\text { al. 2002; Orwa et al. } \\
\text { 2009) }\end{array}$ \\
\hline $\begin{array}{l}\text { Peronema } \\
\text { canescens }\end{array}$ & Lamiaceae & Sungkai & Wood & $\begin{array}{l}\text { Pioneer, light } \\
\text { demanding } \\
\text { (Lawrence 2001) }\end{array}$ \\
\hline Shorea leprosula & Dipterocarpaceae & Meranti & Wood & $\begin{array}{l}\text { Gap opportunist } \\
\text { (Ådjers et al. 1995) } \\
\text { and light demanding } \\
\text { (Bebber et al. 2002) }\end{array}$ \\
\hline
\end{tabular}




\subsubsection{Drone missions and photography}

From September to October 2016, the 56 plots were assessed with an octocopter drone (MikroKopter OktoXL; Mikrokopter, Inc., Germany) equipped with an RGB camera (Nikon D5100, lens AF-S DX NIKKOR 35 mm; Nikon, Japan). The camera was mounted on a gimbal stabilized platform (MK HiSight SLR1; Mikrokopter, Inc., Germany). The optical parameters, such as white balance and focus, were set as automatic mode with an image resolution of $4928 \times 3624$ pixels. The software Mikrokopter-Tool (version 2.14b) was used for planning the drone flight patterns. All missions took place at altitude of $35 \mathrm{~m}$ to $40 \mathrm{~m}$ above ground, i.e. approximately $25 \mathrm{~m}$ above the canopies and were implemented in automatic waypoint mode with a velocity of $2 \mathrm{~m}$ per second and a camera shutter interval of 1 per second in automatic trigger mode. All images were captured with 70\% overlap (end and forward). The drone was set to follow two different flight patterns; one circular and one grid pathway. Two circular flights were conducted with a difference in diameter of $10 \mathrm{~m}$; the radius varied between $26 \mathrm{~m}$ and $40 \mathrm{~m}$, with the plot center as the central point (Appendix Figure 1 and Appendix Table 2). Within the circular pathway, the camera was automatically pointed $45^{\circ}$ from the nadir angle to the plot center. After completing the circular pathway, the drone automatically flew in the grid pathway and the camera angle was set to the nadir angle (Appendix Figure 1). After landing, all recorded images were quality-checked, and unfocused images were deleted. Flight-geo data (GPX-Log files) were processed in GPX Viewer software (version 0.66) and exported as compatible photo-log files with drone images.

\subsubsection{Raster datasets and canopy cover generation}

The Agisoft Photoscan Professional software (version 1.2.6) was used for orthophoto generation, geo-referencing, and point cloud construction through the SfMphotogrammetric approach. In each plot, images with their corresponding photo-log file were processed following standardized steps (including image alignment, building dense point clouds, digital surface model (DSM) and orthophoto generation). The ground control points were used to measure the accuracy of the orthophoto by georeferencing (Appendix Table 2). Subsequently, the RGB orthophoto and DSM were exported in geo-TIFF format, whereas the SfM point clouds were exported in LAS format (Agisoft 2016). This SfM technique provided RGB point clouds with an average density of 2750 points per $\mathrm{m}^{2}$ (standard deviation, $\mathrm{SD} \pm 1320$ ).

LiDAR360 software (version 2.1, GreenValley International, lnc. 2018) was used to compute canopy cover metrics. We derived canopy cover from SfM point clouds. In order to obtain the canopy cover of each plot, we first classified SfM point clouds as "ground" (class 2) and "never-classified" (class 0) with the Classify Ground tool. The never-classified points were expressed as vegetation (Mathews and Jensen 2013). Then, we used the ground points to generate a digital terrain model (DTM) by combining building size, maximum terrain, iteration angle, and distance. After that, all the classified point clouds were normalized by DTM. Furthermore, canopy cover was computed from the normalized point clouds at 1-m height threshold to distinguish 
vegetation parts from ground areas, in the package Forest Stat as equation (1). Finally, a CHM was resampled by subtracting different elevations (m) between DSM and DTM. All raster file outputs were saved in TIFF format with 1-m spatial resolution. We followed these workflows for all 56 plots. We calculated canopy cover with the equation of the LiDAR first return point clouds as:

$$
\text { Canopy cover }=\mathbf{N}_{\text {vegetation }} / \mathbf{N}_{\text {total }}
$$

With $\mathrm{N}_{\text {vegetation }}=$ number of point clouds intersecting the vegetation above the height threshold, $\mathrm{N}_{\text {total }}=$ total number of point clouds (Morsdorf et al. 2006; Ma et al. 2017).

\subsubsection{Hemispheric photography}

Ground-based hemispherical photographs were captured at the center of the 56 plots (Figure 3.1a). Coordinate of plot centers were taken by Garmin GPS device (GPSmap 62; Garmin International, Inc., USA). The circular fish-eye lens (SIGMA $4.5 \mathrm{~mm}$ F2.8 EX DC HSM, field of view $180^{\circ}$ ) and camera (Nikon D5100) were set on a tripod at $1.2 \mathrm{~m}$ height, with the lens pointing exactly zenith. The flash socket was always positioned to the north using a compass (Beaudet and Messier 2002). To avoid overestimation of the canopy gap fraction caused by over-exposure from auto-exposed photographs, we progressively reduced exposure values incrementally by 0.3 until no overexposed pixels presented in the camera screen (Beckschäfer et al. 2013). The selected non-overexposed photographs were processed in Can_Eye software (version 6.47) to identify the vegetation cover fraction in vertical projection as canopy cover (Weiss and Baret 2016). The standard canopy cover was determined using a two-classes method (vegetation and sky without mixed pixels) with zenith angles $60^{\circ}$ (Weiss and Baret 2016). 

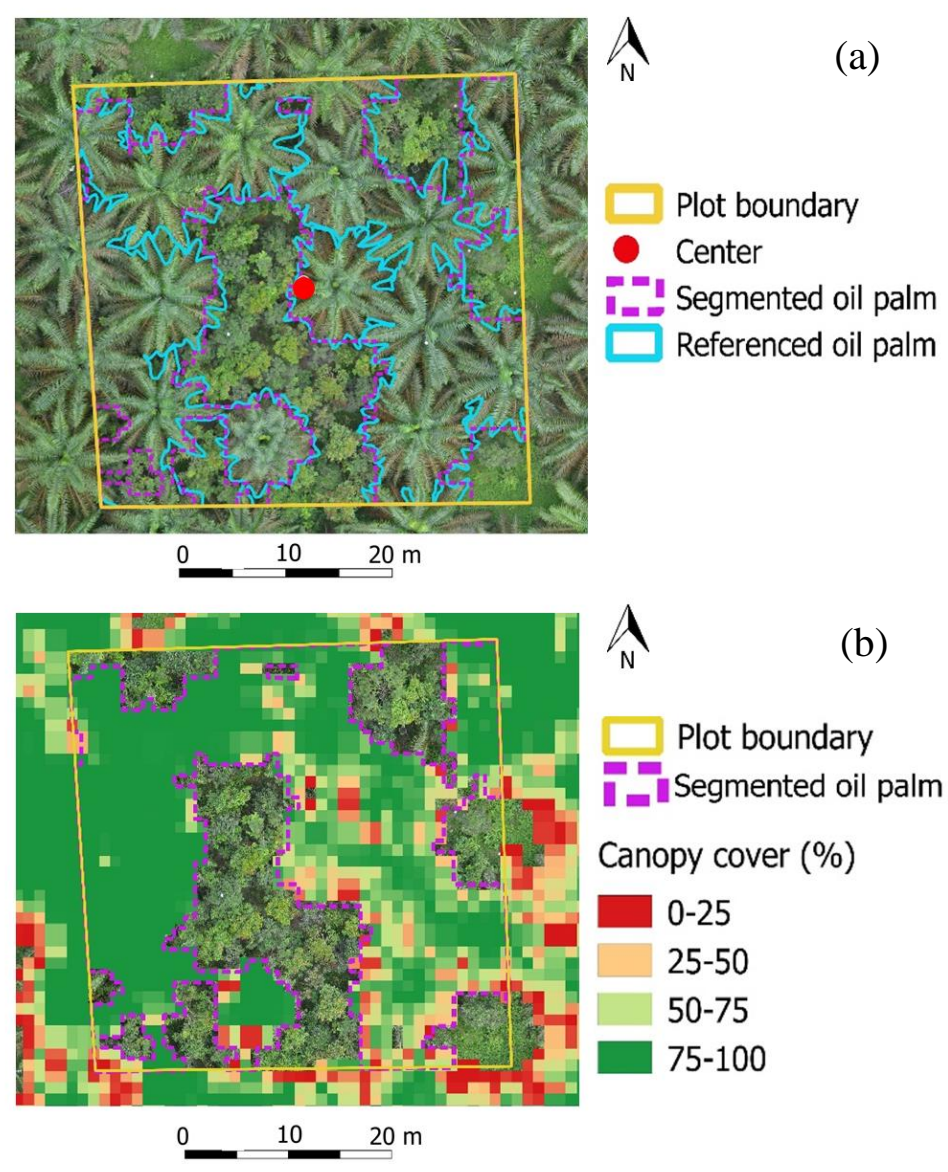

Canopy cover (\%)

$0-25$

$25-50$

50-75

$75-100$
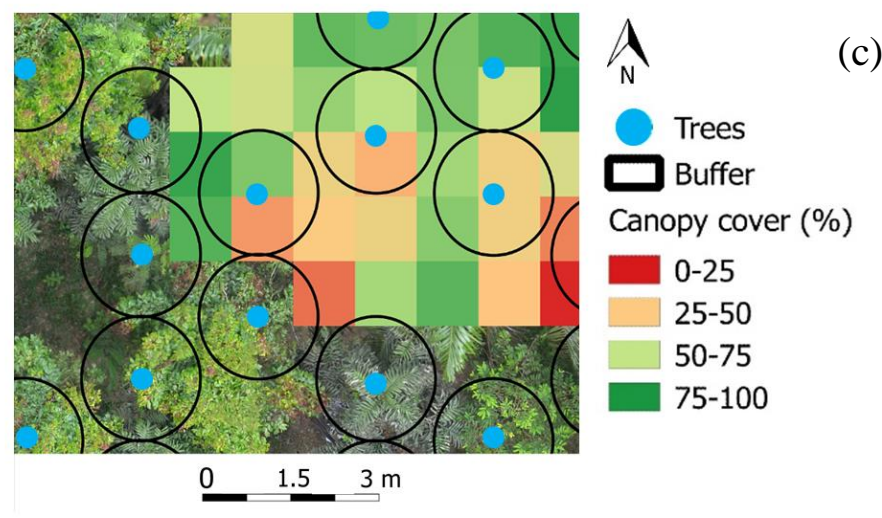

(c)

Figure 3.1. Overview of the biodiversity enrichment experiment (EFForTS-BEE) experimental plot number 23 ( 6 planted tree species, $40 \mathrm{~m} \times 40 \mathrm{~m}$ ): (a) RGB orthophoto map ( $5 \mathrm{~mm}$ pixel-size) overlaid by oil palm canopy segmentations and referenced oil palm. The plot center is shown, where the ground-based hemispherical photograph was taken. (b) Oil palm canopy cover at 1-m resolution; higher values indicate more close canopy, while lower values indicate more open canopy, and (c) extraction of oil palm canopy cover at single tree level with buffers ( $2 \mathrm{~m}$ diameter). 


\subsubsection{Validation of canopy cover}

Drone-derived vegetation canopy cover in each plot was compared with its respective ground-based hemispherical photograph. We considered that tree and oil palm height could affect the size of view of fish-eye images. The average tree and oil palm heights from the CHMs differed (Appendix Table 2). Thus, we estimated the radius (r) of fisheye images from average height CHM with buffer in 10-m diameter, $\theta=$ zenith angles $60^{\circ}$ as equation (2) (Riaño et al. 2004; Leblanc and Fournier 2017).

$$
r=\tan \theta \times \text { average CHM in 10-m diameter buffer }
$$

In each plot, the circular buffer area $\left(\pi r^{2}\right)$ of drone-derived canopy cover was calculated. We assumed that sampling size between canopy cover from drone and hemispherical photographs in each plot were equal. The weighted average was used for extracting pixel values of drone-derived canopy cover (Fieber et al. 2015). The association of drone-derived canopy cover estimates with canopy cover estimates from hemispherical photography were tested using the Pearson correlation coefficient (R) and comparing the estimates to the equality line using coefficient of determination $\left(\mathrm{R}^{2}\right)$ (Figure 3.2). Finally, the significant difference between means of canopy cover from two methods was evaluated using the paired two-sample $t$ test. All raster calculations were done in R program (R Development Core team 2016), with the libraries raster (Hijmans 2016) and rgdal (Bivand et al. 2017).

\subsubsection{Oil palm canopy segmentation}

In each plot, CHM at 1-m spatial resolution was used for oil palm canopy segmentation. We followed the local maximum algorithm with a fixed window size. Firstly, the CHM was smoothed by a Gaussian filter with smoothing-window size at $3 \times 3$ pixels using the FindTreesCHM function in the library rLiDAR (Silva et al. 2017), using the library raster (Hijmans 2016), and rgeos (Bivand and Rundel 2017). Then, a fixed window size at $5 \times 5$ pixels, a specified height threshold at $1 \mathrm{~m}$, and a maximum crown radius at $12 \mathrm{~m}$ were applied in order to retrieve automatically delineated crown polygons with the function ForestCAS in the library rLiDAR (Silva et al. 2017). All steps were conducted in $\mathrm{R}$ program (R Development Core team 2016).

We partitioned oil palm canopy from other tree canopies by manual selecting the oil palm crown polygons within the RGB orthomosaic overlay, following semi-individual tree-crown approach (Breidenbach et al. 2010). All selected polygons were merged and categorized as segmented oil palm canopy (Figure 3.1a), and the other polygons were categorized as tree canopy and open area. The accuracy was assessed using equations 3-5 after matching objects with manual-referenced oil palm polygons using the Intersect tool in ArcGIS (version 10.4, Clinton et al. 2010; Kumar 2012). Moreover, oil palm canopy cover from thinned and non-thinned plots were compared by quantifying the frequency of pixels within interval of $20 \%$ for oil palm canopy cover classes (0$20 \%, 20-40 \%, 40-60 \%, 60-80 \%$ and $80-100 \%$, Figure 3.3). 
Over segmentation $=1-\frac{\text { area }(\text { referenced oil palm } \cap \text { segmented oil palm })}{\text { area }(\text { referenced oil palm })}$

Under segmentation $=1-\frac{\text { area }(\text { referenced oil palm } \cap \text { segmented oil palm })}{\text { area }(\text { segmented oil palm })}$

$$
\operatorname{Error}(\%)=\frac{\sqrt{\text { over segmentation }^{2}+\text { under segmentation }^{2}}}{\sqrt{2}} \times 100
$$

\subsubsection{Oil palm canopy cover extraction at individual tree level}

We manually co-registered the coordinates of living trees from 2016 within their corresponding RGB orthophoto. For each living tree, we systematically designed circular buffers of $2 \mathrm{~m}$ diameter, consistent with the initial distances between planted trees, as sampling area for oil palm canopy cover extraction (Figure 3.1c). The mean value of oil palm canopy cover was quantified for each living tree. Due to the shape of the circular buffers, raster cells on edges were not totally covered by polygons; a weighted function was then used to calculate the mean value proportionally (Fieber et al. 2015). Data processing was done in R program (R Development Core team 2016) in library raster (Hijmans 2016) and rgdal (Bivand et al. 2017).

\subsubsection{Tree mortality assessments}

Living trees were recorded in the 48 plots by annual field inventory in January 2016, and again in January 2017. Mortality was monitored by bark scratching and visual inspection. Erroneous mortality diagnostics revealed from the inventory conducted in 2018 were corrected (30 trees in total). The total number of living trees in 2016 was 3819 (Appendix Table 1 and Appendix Table 3), and number of trees that died between 2016 and 2017 was 507 (Appendix Table 1). The percentage of one-year species mortality (2016-2017) in each oil palm canopy cover class 's' was calculated as equation (6).

$$
\operatorname{Mortality}_{s}(\%)=\frac{N_{-} \text {dead }}{N_{\text {_alive }}+N_{s} \text { dead }_{s}} \times 100
$$

Where ' $\mathrm{s}$ ' indicates canopy cover class, N_dead = number of trees that died and N_alive $=$ number of trees that survived between 2016 and 2017 .

The dependency of tree mortality on oil palm canopy cover class could not be tested using a standard contingency test because tree mortality in many classes was too low (Figure 3.4). We thus used Fisher's Exact and pairwise tests to address the dependency between oil palm canopy cover class and the number of trees that died and survived 
between 2016 and 2017. The null hypothesis is that the proportion of trees that died and survived is independent of oil palm canopy cover class.

\subsection{Results}

\subsubsection{Canopy cover estimation at plot level}

At the plot center, canopy cover derived from drone-based point clouds ranged from $0 \%$ to $99 \%$ across the 56 experimental plots (Figure 3.2). Drone-derived canopy cover estimates (y) were highly correlated with ground-based hemispherical photography $(\mathrm{x})$ with $\mathrm{R}=0.94(p<0.01)$. The equality line $(\mathrm{y}=\mathrm{x})$ fitted well to the data $\left(\mathrm{R}^{2}=0.84, p\right.$ $<0.01)$ and no significant differences were found between the two estimates $(t$-value $=$ $-0.05, p>0.05)$ with root mean squared error $(\mathrm{RMSE})=10.83 \%$. However, there was a deviation between low to mid ranges of canopy cover (20\% to $50 \%$ ), where the dronebased method estimated higher canopy cover than the ground-based estimation (Figure $3.2)$.

Based on drone estimates with resolution scale of $1 \mathrm{~m}$ covering 48 agroforestry plots, the mean vegetation canopy cover was $70 \%$ ( $\mathrm{SD} \pm 11 \%$ ). The canopy cover from the oil palms was $56 \%$ (SD $\pm 17 \%$ ) and the canopy cover from the planted trees was $15 \%$ ( $\mathrm{SD} \pm 13 \%$ ). The accuracy of oil palm canopy segmentation is estimated to be $91 \%$ (SD $\pm 5 \%$ ). The frequency of pixels across canopy cover classes followed a U-shape distribution in both thinned and non-thinned plots (Figure 3.3). Pixels with 0 to $20 \%$ of oil palm canopy cover were twice more frequent in thinned plots than non-thinned plots (Figure 3.3). On the other hand, pixels with dense oil palm canopy cover (80-100\%) were $37 \%$ less frequent in non-thinned plots than in thinned plots (Figure 3.3). 


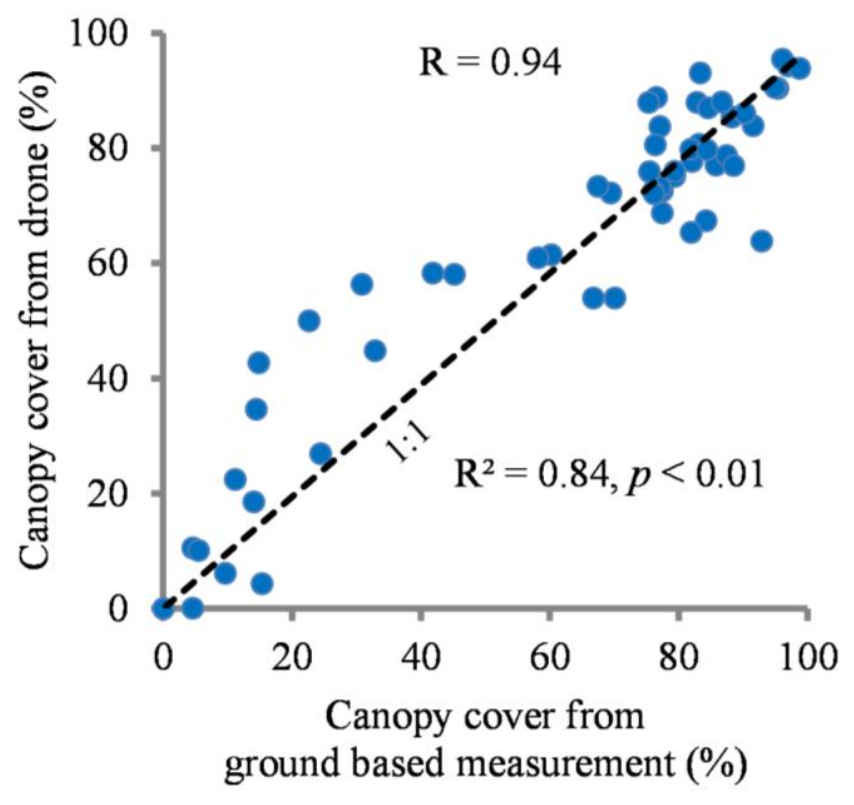

Figure 3.2. Drone-derived canopy cover compared to ground-based hemispherical photography at plot center $(\mathrm{N}=56$ plots $)$ with a correlation coefficient $(\mathrm{R})=0.94$, RMSE $=10.83 \%$. The equality line (black dashed line) indicates $1: 1$ relationship with $\mathrm{R}^{2}=0.84, p<0.01$.

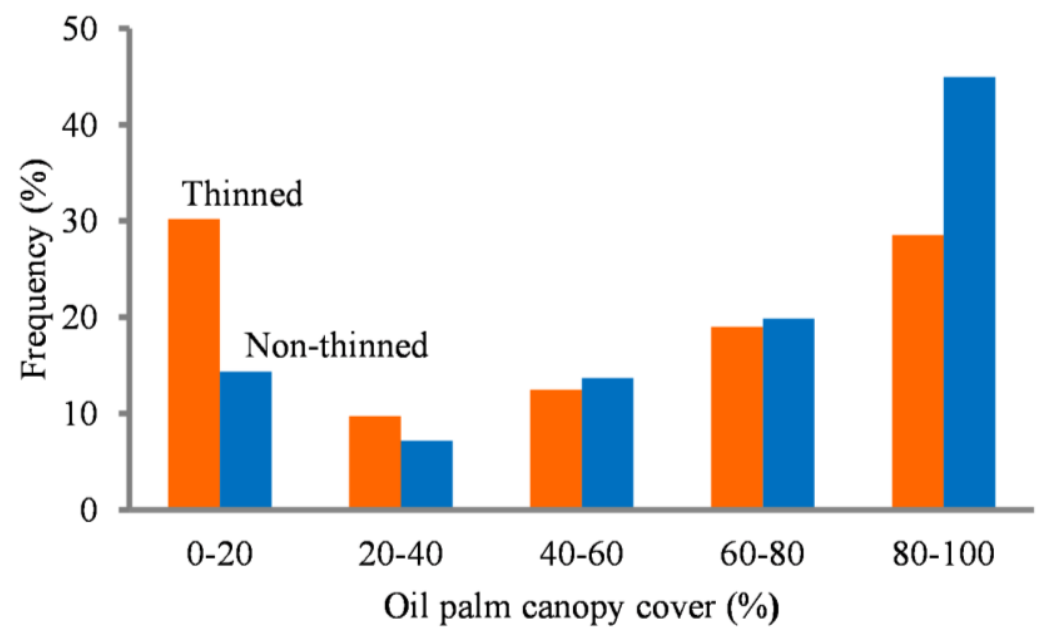

Figure 3.3. Distribution of oil palm canopy cover in thinned and non-thinned plots where trees were planted $\left(\mathrm{N}_{\text {thinned }}=24870\right.$ pixels and $\mathrm{N}_{\text {non-thinned }}=307$ pixels, in 48 plots). 


\subsubsection{Oil palm canopy cover related to tree mortality}

Field-based inventory indicated that the overall mortality of the six tree species between 2016 and 2017 was $13 \%$ but differed significantly among species. D. zibethinus and $S$. leprosula had high mortality rates (39\% $\mathrm{yr}^{-1}$ and $47 \% \mathrm{yr}^{-1}$, respectively), while $A$. pauciflorum, D. polyphylla, $P$. speciosa and $P$. canescens had low mortality rates (less than $10 \% \mathrm{yr}^{-1}$, Appendix Table 3).

The proportion of trees that died and survived for the three tree species, A. pauciflorum, D. zibethinus and S. leprosula, was dependent on oil palm canopy cover class (Figure 3.4), whereas no significant dependency was detected for the other three tree species (Fisher exact test, two-tailed $p>0.05$ ). A. pauciflorum and S. leprosula presented higher mortality rates with increasing oil palm canopy cover, while D. zibethinus presented decreasing mortality rates with increasing oil palm canopy cover (Figure 3.4). 
Archidendron pauciflorum*

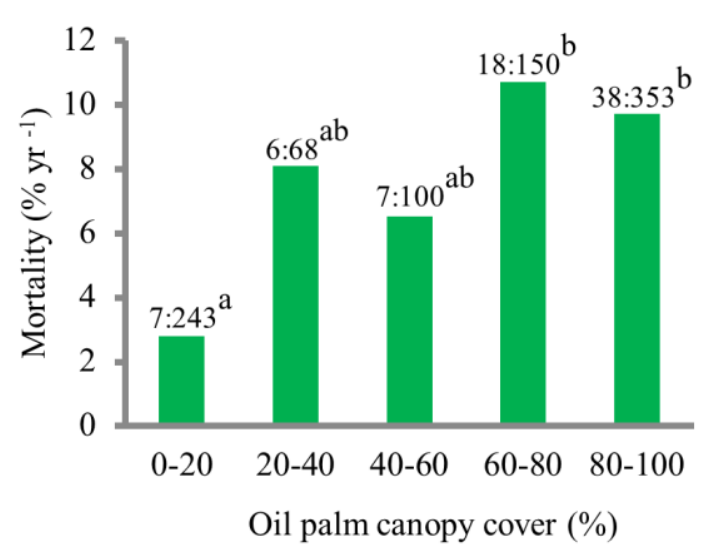

Dyera polyphylla

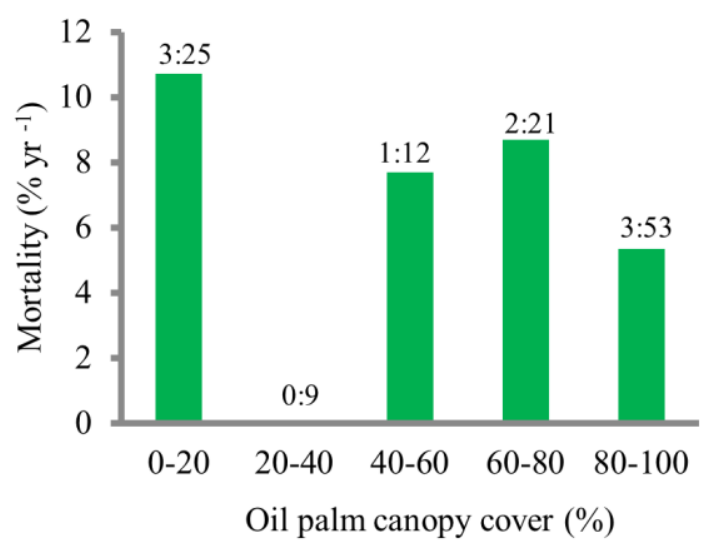

Peronema canescens

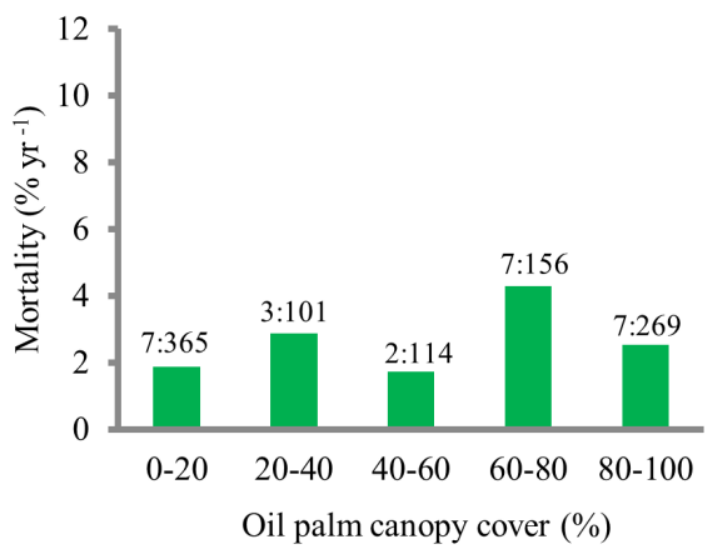

Durio zibethinus*

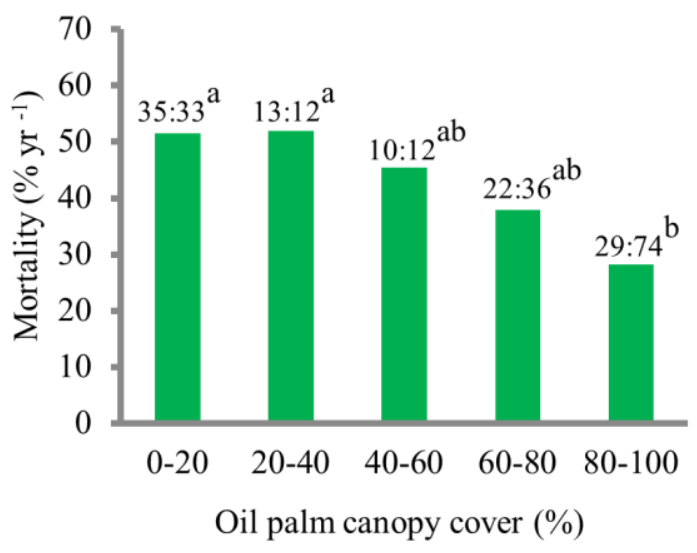

Parkia speciosa
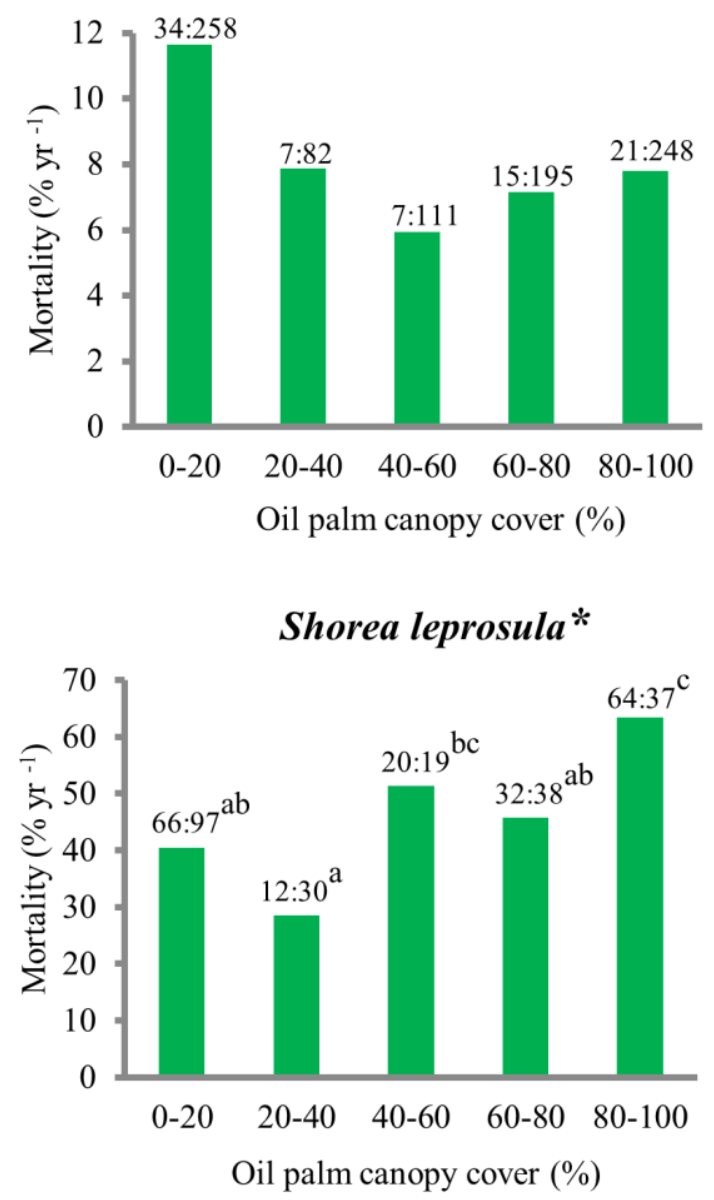

Figure 3.4. Tree mortality $\left(\% \mathrm{yr}^{-1}\right)$ between January 2016 and January 2017 within oil palm canopy cover. ' $*$ ' indicates tree species with proportions of trees that died and survived between 2016 and 2017 dependent on oil palm canopy cover class (two-tailed $p<0.05$, Fisher's Exact test). The number of trees that died (N_dead) and survived (N_alive) are indicated above the bars (N_dead:N_alive) and the letters represent differences among oil palm canopy cover classes $(p<0.05$, pairwise test of independence). The total number of living trees in 2016 and number of dead trees in 2017 were 3819 and 507, respectively. 


\subsection{Discussion}

We generated canopy cover maps at a high spatial resolution in oil-palm agroforests using drone-based photogrammetry, partitioned canopy cover into oil palms and trees, and analyzed the relationship between oil palm canopy cover and tree mortality.

We integrated different flight patterns and camera angles to generate high density point clouds following a well-documented photogrammetry procedure (Cunliffe et al. 2016; Vacca et al. 2017). The employed SfM technique resulted in a very high density of photogrammetric point clouds (mean $=2,750$ points per $\mathrm{m}^{2}$ ). In a previous study observing canopy cover with LiDAR point clouds, the density of 10 points per $\mathrm{m}^{2}$ already yielded reasonable results when compared with ground-based measurements using a Cajanus sighting tube (Ma et al. 2017). Therefore, it is clear that point cloud density from SfM technique is high enough to derive reliable canopy cover estimates.

We found a high correlation between drone-derived canopy cover and ground-based hemispherical photography. Despite the high correlation, drone-derived canopy cover estimates were higher than ground-based estimates at $20 \%$ to $50 \%$ of canopy cover (Figure 3.2). The SfM point clouds resulted in overestimated canopy cover compared to the LiDAR point clouds estimates probably due to limited penetration ability; however, mean canopy cover derived from the two different methods did not differ significantly (99\% confidence level) in a previous study (Jayathunga et al. 2018) and in our own. A similar deviation was observed by Chianucci et al. (2016) who found that canopy cover from drone-based RGB image classification was higher than groundbased photography estimation. We assume that small canopy gaps might be undetectable from SfM point clouds, as it was also the case in canopy analyses from LiDAR point clouds (Vaccari et al. 2013). A single picture of the aerial photography may potentially have similar resolution as the ground-based pictures, but the SfM approach includes numerous pictures from different angles with a certain overlap. Such methodological differences might explain the observed difference in estimations at low to intermediate canopy cover. Nevertheless, the high correlation between the SfM technique and ground-based hemispherical photography strongly suggests comparability of our approach.

Based on semi-individual tree-crown approach (Breidenbach et al. 2010), the oil palm canopy segmentation is a crucial step to partition the canopy cover into oil palms by overlaying oil palm crown polygons with RGB orthophotos. This procedure resulted in useful and precise data but leaves room for further optimization, because using only the automatic crown segmentation of the CHM did not always differentiate oil palm canopy from trees. Furthermore, in order to improve the accuracy of crown segmentation, different window sizes relative to image resolutions and varying tree-crown sizes could be tested (Wulder et al. 2000; Silva et al. 2016; Mohan et al. 2017). One advantage of our method was that we could retrieve oil palm canopy cover at the level of individual trees using their spatial coordinates, and this was possible even when planted trees were 
invisible from RGB images because they grew under neighbor trees and oil palm canopies.

An analysis of our map of oil palm canopy cover suggests that thinning oil palms created more variable canopy cover conditions. Specifically, thinned plots presented twice as many pixels in open areas ( $0 \%$ to $20 \%$ oil palm canopy cover class) and $37 \%$ less pixels in shaded areas ( $80 \%$ to $100 \%$ oil palm canopy cover) compared to nonthinned plots.

The probability of mortality rates of A. pauciflorum, D. zibethinus and S. leprosula depended on the amount of oil palm canopy cover (Figure 3.4). The relationship between oil palm canopy cover and mortality can be related to light requirements of each species (Table 3.1); however, a clear relationship between oil palm shading and tree mortality was not present for other tree species. Long-term monitoring of tree mortality may be required to elucidate relationship for these remaining species. Moreover, further analysis of other potentially important control factors affecting mortality should be conducted. For example, planted trees might have also suffered from the extreme drought period associated with El Niño event in 2015 (Meijide et al. 2018), even though the drought ended several months before our study period (Nieuwstadt and Sheil 2005).

Oil palm companies have only begun to utilize remote sensing monitoring technology for developing more sustainable management schemes (Chong et al. 2017). Our dronebased methods efficiently differentiated oil palm from tree canopies and clearly depicted the canopy structure of dominant oil palms. Furthermore, we were able to show with our method that thinning created heterogeneous oil palm canopy cover and that oil palm canopy conditions partly influenced mortality of some tree species in the biodiversity enrichment experiment.

\subsection{Conclusions}

Drone-based photogrammetry and subsequent partitioning of dominant oil palm canopies present advantages in canopy cover analyses of oil palm agroforestry. In the case of transforming oil palm monocultures into agroforestry systems, drone-derived canopy cover can be utilized to address many other questions with respect to agroforestry system management and ecological study. 


\section{Acknowledgments}

This study was funded in part by the Deutsche Forschungsgemeinschaft (DFG, German Research Foundation) - project number 192626868 - SFB 990 in the framework of the collaborative German - Indonesian research project CRC990. Watit Khokthong received a PhD fellowship from the Royal Government of Thailand within the Development and Promotion of Science and Technology Talents Project (DPST). We acknowledge support by Open Access Publication Fund of University of Goettingen. We would like to thank Joshua André Erkelenz, Juliandi and Zulfi Kamal for help in the field, Benjamin Wagner for suggestions R libraries for canopy segmentation, and Peter Pütz for valuable suggestions regarding statistical tests.

\subsection{Reference (Chapter 3)}

Agisoft. 2016. Agisoft PhotoScan user manual: professional edition, version 1.2. Available at: http://www.agisoft.com/pdf/photoscan-pro_1_2_en.pdf (Accessed August 25, 2016).

Allen, K., Corre, M. D., Tjoa, A., \& Veldkamp, E. 2015. Soil nitrogen-cycling responses to conversion of lowland forests to oil palm and rubber plantations in Sumatra, Indonesia. PLoS ONE 10.

Ashraf, M., Zulkifli, R., Sanusi, R., Tohiran, K. A., Terhem, R., Moslim, R., ... Azhar, B. 2018. Alley-cropping system can boost arthropod biodiversity and ecosystem functions in oil palm plantations. Agriculture, Ecosystems \& Environment 260: $19-26$.

Aumeeruddy, Y. 1994. Local representations and management of agroforests on the periphery of Kerinci Seblat national park, Sumatra, Indonesia. in People and Plants working paper 3. The United Nations Educational, Scientific and Cultural Organization, Paris.

Awal, M. A., \& Wan Ishak, W. I. 2008. Measurement of oil palm LAI by manual and LAI-2000 method. Asian Journal of Scientific Research 1: 49-56.

Awal, M. A., Wan Ishak, W. I., \& Bockari-Gevao, S. M. 2010. Determination of leaf area index for oil palm plantation using hemispherical photography technique. Pertanika Journal of Science and Technology 18: 23-32.

Azhar, B., Saadun, N., Puan C. L., Kamarudin, N., Aziz, N., Nurhidayu, S., \& Fischer, J. 2015. Promoting landscape heterogeneity to improve the biodiversity benefits of certified palm oil production: evidence from peninsular Malaysia. Global Ecology and Conservation 3: 553-561.

Ådjers, G., Hadengganan, S., Kuusipalo, J., Nuryanto, K., \& Vesa, L. 1995. Enrichment planting of dipterocarps in logged-over secondary forests: effect of width, direction and maintenance method of planting line on selected Shorea species. Forest Ecology and Management 73: 259-270. 
Banu, T. P., Borlea, G. F., \& Banu, C. 2017. Determination of the forest canopy cover using a low-cost commercial drone. Research Journal of Agricultural Science 49: $12-17$.

Barnes, A. D., Jochum, M., Mumme, S., Haneda, N. F., Farajallah, A., Widarto, T. H., \& Brose, U. 2014. Consequences of tropical land use for multitrophic biodiversity and ecosystem functioning. Nature Communications 5.

Barrios, E., Valencia, V., Jonsson, M., Brauman, A., Hairiah, K., Mortimer, P. E., \& Okubo, S. 2017. Contribution of trees to the conservation of biodiversity and ecosystem services in agricultural landscapes. International Journal of Biodiversity Science, Ecosystem Services \& Management 14: 1-16.

Beaudet, M., \& Messier, C. 2002. Variation in canopy openness and light transmission following selection cutting in northern hardwood stands: an assessment based on hemispherical photographs. Agricultural and Forest Meteorology 110: 217-228.

Bebber, D., Brown, N., Speight, M., Moura-Costa, P., \& Wai, Y. S. 2002. Spatial structure of light and dipterocarp seedling growth in a tropical secondary forest. Forest Ecology and Management 157: 65-75.

Beckschäfer, P., Seidel, D., Kleinn, C., \& Xu, J. 2013. On the exposure of hemispherical photographs in forests. IForest 6: 228-237.

Bhagwat, S. A., Willis, K. J., Birks, H. J. B., \& Whittaker, R. J. 2008. Agroforestry: a refuge for tropical biodiversity?. Trends in Ecology and Evolution 23: 261-267.

Bivand, R., \& Rundel, C. 2017. Rgeos: interface to geometry engine - open source ('GEOS'). $\mathrm{R}$ package version 0.3-26. Available at: https://CRAN.Rproject.org/package $=$ rgeos.

Bivand, R., Keitt, T., \& Rowlingson, B. 2017. Rgdal: bindings for the 'geospatial' data abstraction library. R package version 1.2-16. Available at: https://CRAN.Rproject.org/package $=$ rgdal.

Breidenbach, J., Nasset, E., Lien, V., Gobakken, T., \& Solberg, S. 2010. Prediction of species specific forest inventory attributes using a nonparametric semi-individual tree crown approach based on fused airborne laser scanning and multispectral data. Remote Sensing of Environment 114: 911-924.

Chianucci, F., Disperati, L., Guzzi, D., Bianchini, D., Nardino, V., Lastri, C., ... Corona, P. 2016. Estimation of canopy attributes in beech forests using true colour digital images from a small fixed-wing UAV. International Journal of Applied Earth Observation and Geoinformation 47: 60-68.

Chong, K. L., Kanniah, K. D., Pohl, C., \& Tan, K. P. 2017. A review of remote sensing applications for oil palm studies. Geo-spatial Information Science 20: 184-200.

Clinton, N., Holt, A., Scarborough, J., Yan, L., \& Gong, P. 2010. Accuracy assessment measures for object-based image segmentation goodness. Photogrammetric Engineering \& Remote Sensing 76: 289-299.

Clough, Y., Krishna, V. V., Corre, M. D., Darras, K., Denmead, L. H., Meijide, A., ... Scheu, S. 2016. Land-use choices follow profitability at the expense of ecological functions in Indonesian smallholder landscapes. Nature Communications 7. 
Cunliffe, A. M., Brazier, R. E., \& Anderson, K. 2016. Ultra-fine grain landscape-scale quantification of dryland vegetation structure with drone-acquired structurefrom-motion photogrammetry. Remote Sensing of Environment 183: 129-143.

Davidson, R., Mauffette, Y., and Gagnon, D. 2002. Light requirements of seedlings: a method for selecting tropical trees for plantation forestry. Basic and Applied Ecology 3: 209-220.

Dislich, C., Keyel, A. C., Salecker, J., Kisel, Y., Meyer, K. M., Auliya, M., ... Faust, H. 2017. A review of the ecosystem functions in oil palm plantations, using forests as a reference system. Biological Reviews 92 (3): 1539-1569.

Drescher, J., Rembold, K., Allen, K., Beckschäfer, P., Buchori, D., Clough, Y., ... Scheu, S. 2016. Ecological and socio-economic functions across tropical land use systems after rainforest conversion. Philosophical Transactions of the Royal Society B 371 .

Euler, M., Schwarze, S., Siregar, H., \& Qaim, M. 2016. Oil palm expansion among smallholder farmers in Sumatra, Indonesia. Journal of Agricultural Economics 67: 658-676.

FAO. 2016. FAOSTAT online statistical service. Available at: http://faostat.fao.org (Accessed May 31, 2018).

Fieber, K. D., Davenport, I. J., Tanase, M. A., Ferryman, J. M., Gurney, R. J., Becerra, V. M., ... Hacker, J. M. 2015. Validation of canopy height profile methodology for small-footprint full-waveform airborne LiDAR data in a discontinuous canopy environment. ISPRS Journal of Photogrammetry and Remote Sensing 104: 144-157.

Foster, W. A., Snaddon, J. L., Turner, E. C., Fayle, T. M., Cockerill, T. D., Ellwood, M. D. F., ... Yusah, K. M. 2011. Establishing the evidence base for maintaining biodiversity and ecosystem function in the oil palm landscapes of South East Asia. Philosophical Transactions of the Royal Society B 366: 3277-3291.

Gérard, A., Wollni, M., Hölscher, D., Irawan, B., Sundawati, L., Teuscher, M., \& Kreft, H. 2017. Oil-palm yields in diversified plantations: initial results from a biodiversity enrichment experiment in Sumatra, Indonesia. Agriculture, Ecosystems and Environment 240: 253-260.

Graham, L. L. B., Giesen, W., \& Page, S. E. 2017. A common-sense approach to tropical peat swamp forest restoration in Southeast Asia. Restoration Ecology 25: 312-321.

GreenValley International, lnc. 2018. LiDAR360 user guide, version 2.0. Available at: http://www.greenvalleyintl.com (Accessed January 25, 2018).

Guo, Q., Su, Y., Hu, T., Zhao, X., Wu, F., Li, Y., ... Wang, X. 2017. An integrated UAV-borne LiDAR system for 3D habitat mapping in three forest ecosystems across China. International Journal of Remote Sensing 38: 2954-2972.

Harja, D., Vincent, G., Mulia, R., \& van Noordwijk, M. 2012. Tree shape plasticity in relation to crown exposure. Trees 26: 1275-1285.

Hijmans, R. J. 2016. Raster: geographic data analysis and modeling. R package version 2.8-4. Available at: https://CRAN.R-project.org/package=raster. 
Ivosevic, B., Han, Y. G., \& Kwon, O. 2017. Calculating coniferous tree coverage using unmanned aerial vehicle photogrammetry. Journal of Ecology and Environment 41: 4-11.

Jayathunga, S., Owari, T., \& Tsuyuki, S. 2018. Evaluating the performance of photogrammetric products using fixed-wing UAV imagery over a mixed coniferbroadleaf forest: comparison with airborne laser scanning. Remote Sensing 10.

Jennings, S. B., Brown, N. D., \& Sheil, D. 1999. Assessing forest canopies and understorey illumination: canopy closure, canopy cover and other measures. Forestry 72: 59-74.

Jose, S. 2012. Agroforestry for conserving and enhancing biodiversity. Agroforest Systems 85: 1-8.

Konopik, O., Gray, C. L., Grafe, T. U., Steffan-Dewenter, I., \& Fayle, T. M. 2014. From rainforest to oil palm plantations: shifts in predator population and prey communities, but resistant interactions. Global Ecology Conservation 2: 385394.

Koh, L. P., Levang, P., \& Ghazoul, J. 2009. Designer landscapes for sustainable biofuels. Trends in Ecology and Evolution 24: 431-438.

Korhonen, L., Korhonen, K. T., Rautiainen, M., \& Stenberg, P. 2006. Estimation of forest canopy cover: a comparison of field measurement techniques. Silva Fennica 40: 577-588.

Kumar, V. 2012. Forest inventory parameters and carbon mapping from airborne LiDAR. Master thesis. University of Twente, Enschede, Netherlands.

Lawrence, D. 2001. Nitrogen and phosphorus enhance growth and luxery consumption of four secondary tree species in Borneo. Journal of Tropical Ecology 17: 859869.

Leblanc, S. G., \& Fournier, R. A. 2017. "Measurement of forest structure with hemispherical photography," in Hemispherical Photography in Forest Science: Theory, Methods, Applications, eds Fournier, R. A. \& Hall, R. J. (Springer Science + Business Media): 53-84.

Lee, C. T., Wickneswari, R., Clyde, M. M., \& Zakri, A. H. 2002. Maintenace of genetic diversity in Parkia speciosa in logged-over forests. Journal of Tropical Forest Science 14: 163-178.

Ma, Q., Su, Y., \& Guo, Q. 2017. Comparison of canopy cover estimations from airborne LiDAR, aerial imagery, and satellite imagery. IEEE Journal of Selected Topics in Applied Earth Observatins and Remote Sensing.

Mailly, D. 2017. "Hemispherical photography in support of forest inventory and silviculture," in Hemispherical Photography in Forest Science: Theory, Methods, Applications, eds Fournier, R. A. \& Hall, R. J. (Springer Science + Business Media): 227-252.

Mathews, A. J., \& Jensen, J. L. R. 2013. Visualizing and quantifying vineyard canopy LAI using an unmanned aerial vehicle (UAV) collected high density structure from motion point cloud. Remote Sensing 5: 2164-2183. 
Meijide, A., Badu, C. S., Moyano, F., Tiralla, N., Gunawan, D., \& Knohl, A. 2018. Impact of forest conversion to oil palm and rubber plantations on microclimate and the role of the 2015 ENSO event. Agricultural and Forest Meteorology 252: 208-219.

Mohan, M., Silva, C. A., Klauberg, C., Jat, P., Catts, G., Cardil, A., ... Dia, M. 2017. Individual tree detection from unmanned aerial vehicle (UAV) derived canopy height model in an open canopy mixed conifer forest. Forests 8.

Morsdorf, F., Kötz, B., Meier, E., Itten, K. I., \& Allgöwer, B. 2006. Estimation of LAI and fractional cover from small footprint airborne laser scanning data based on gap fraction. Remote Sensing of Environment 104 : 50-61.

Nevalainen, O., Honkavaara, E., Tuominen, S., Viljanen, N., Hakala, T., Yu, X., ... Tommaselli, A. M. G. 2017. Individual tree detection and classification with UAV-based photogrammetric point clouds and hyperspectral imaging. Remote Sensing 9.

Nieuwstadt, M. G. L. V., \& Sheil, D. 2005. Drought, fire and tree survival in a Borneo rain forest, East Kalimantan, Indonesia. Journal of Ecology 93: 191-201.

Nguyen, H., Lamb, D., Herbohn, J., \& Firn, J. 2014. Designing mixed species tree plantations for the tropics: balancing ecological attributes of species with landholder preferences in the Philippines. PLOS ONE 9.

Nunes, M. H., Ewers, R. M., Turner, E. C., \& Coomes, D. A. 2017. Mapping aboveground carbon in oil palm plantations using LiDAR: a comparison of treecentric versus area-based approaches. Remote Sensing 9.

Orwa, C., Mutua, A., Kindt, R., Jamnadass, R., \& Simons, A. 2009. Agroforest tree database: a tree reference and selection guide version 4.0. Available at: http://www.worldagroforestry.org/output/agroforestree-database (Accessed June 11, 2018).

Prastyaningsih, S. R. \& Azwin. 2017. The growth of agarwood plants on the different canopy covers level and fertilizer in oil palm plantation. IOP Conference Series: Earth and Environmental 97.

Riaño, D., Valladares, F., Condés, S., \& Chuvieco, E. 2004. Estimation of leaf area index and covered ground from airborne laser scanner (LiDAR) in two contrasting forests. Agricultural and Forest Meteorology 124: 269-275.

Rist, L., Laurène, F., \& Levang, P. 2010. The livelihood impacts of oil palm: smallholders in Indonesia. Biodiversity and Conservation 19: 1009-1024.

R Development Core Team. 2016. R: A language and environment for statistical computing. R Foundation for Statistical Computing, Vienna, Austria.

Shin, P., Sankey, T., Moore, M. M., \& Thode, A. E. 2018. Evaluating unmanned aerial vehicle images for estimating forest canopy fuels in a Ponderosa pine stand. Remote Sensing 10.

Silva, C. A., Hudak, A. T., Vierling, L. A., Loudermilk, E. L., O’Brien, J. J., Hiers, J. K., ... Khosravipour, A. 2016. Imputation of individual longleaf pine (Pinus Palustris Mill.) tree attributes from field and LiDAR data. Canadian Journal of Remote Sensing 42: 554-573. 
Silva, C. A., Crookston, N. L., Hudak, A. T., Vierling, L. A., Klauberg, C., \& Silva, M. C. A. 2017. Package 'rLiDAR.'

Teuscher, M., Gérard, A., Brose, U., Buchori, D., Clough, Y., Ehbrecht, M., ... Kreft, H. 2016. Experimental biodiversity enrichment in oil-palm-dominated landscapes in Indonesia. Frontiers in Plant Science 7.

Torres-Sánchez, J., Peña, J. M., de Castro, A. I., \& López-Granados, F. 2014. Multitemporal mapping of the vegetation fraction in early-season wheat fields using images from UAV. Computers and Electronics in Agriculture 103: 104-113.

Tscharntke, T., Tylianakis, J. M., Rand, T. A., Didham, R. K., Fahrig, L., Batary, P., ... Westphal, C. 2012. Landscape moderation of biodiversity patterns and processes - eight hypotheses. Biological Reviews 87: 661-685.

Vacca, G., Dessì, A., \& Sacco, A. 2017. The use of nadir and oblique UAV images for building knowledge. ISPRS International Journal of Geo-Information 6.

Vaccari, S., Leeuwen, M. V., Calders, K., Coops, N. C., \& Herold, M. 2013. Bias in LiDAR-based canopy gap fraction estimates. Remote Sensing Letters 4: 391-399.

Vijay, V., Pimm, S. L., Jenkins, C. N., \& Smith, S. J. 2016. The impacts of oil palm on recent deforestation and biodiversity loss. PLOS ONE 11.

Wallace, L., Lucieer, A., Malenovskỳ, Z., Turner, D., \& Vopěnka, P. 2016. Assessment of forest structure using two UAV techniques: a comparison of airborne laser scanning and structure from motion (SfM) point clouds. Forests 7: 1-16.

Weiss, M., \& Baret, F. 2016. Can_eye v6.4.6 user manual. Available online at: https://www6.paca.inra.fr/can-eye/Documentation/Documentation (Accessed March 10, 2017).

Wulder, M., Niemann, K. O., \& Goodenough, D. G. 2000. Local maximum filtering for the extraction of tree locations and basal area from high spatial resolution imagery. Remote Sensing of Environment 73: 103-114.

Zhang, J., Hu, J., Lian, J., Fan, Z., Ouyang, X., \& Ye, W. 2016. Seeing the forest from drones: testing the potential of lightweight drones as a tool for long-term forest monitoring. Biological Conservation 198: 60-69. 


\subsection{Appendix (Chapter 3)}
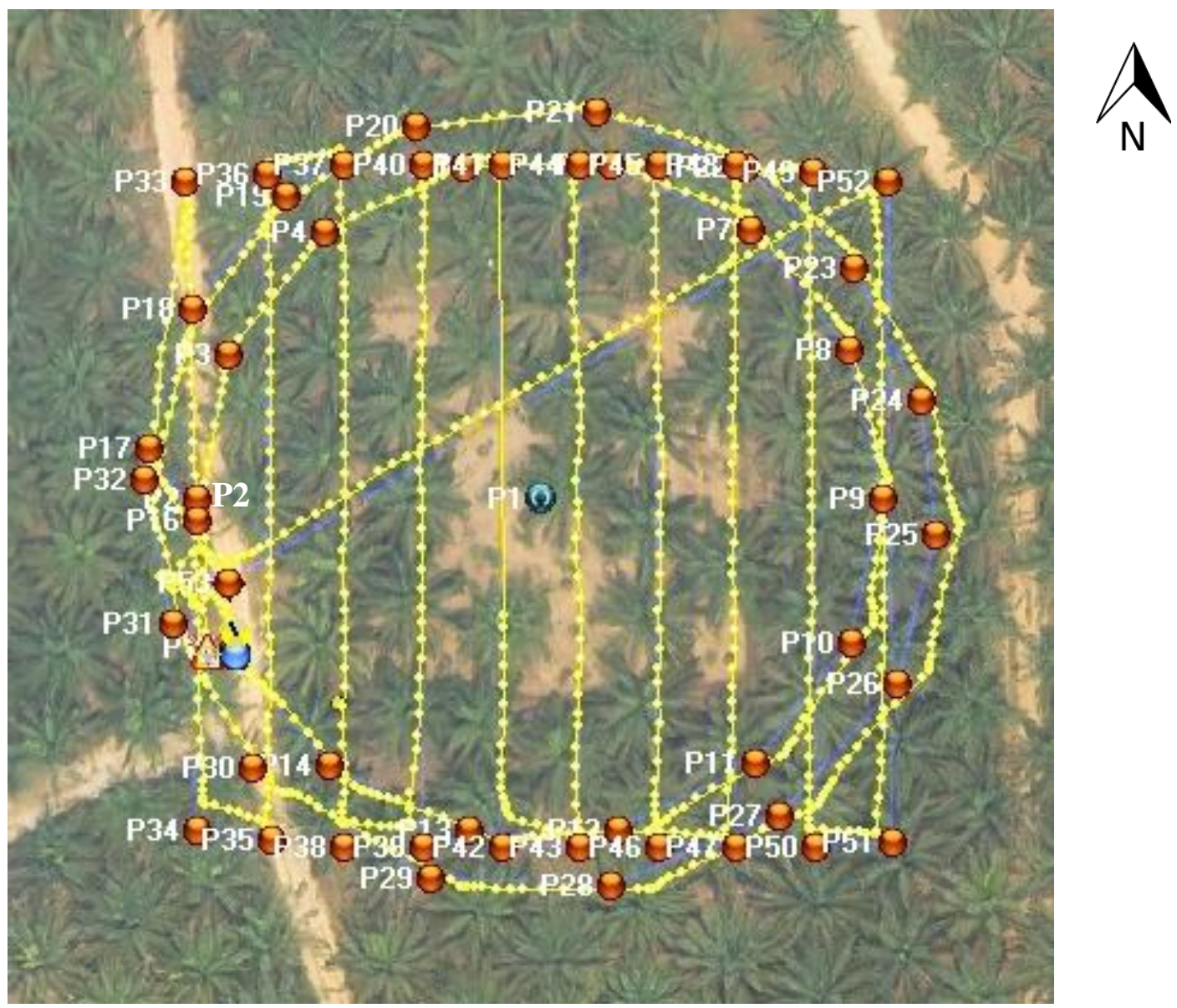

Appendix Figure 1. Example flight pattern at plot number 23 (plot size $1600 \mathrm{~m}^{2}$ ). Two circular flights were conducted with the first circular flight (P2 to P16) at a radius of 35 $\mathrm{m}$ from the plot center (P1), and the second circular flight (P17 to $\mathrm{P} 32$ ) at a radius of $40 \mathrm{~m}$. After that, the grid pathway automatically began by flying between P33 and P52. 
Appendix Table 1. Summary table of plot information and recorded trees in 2016 and 2017.

\begin{tabular}{|c|c|c|c|c|c|c|c|c|}
\hline $\begin{array}{l}\text { Plot } \\
\text { ID }\end{array}$ & $\begin{array}{c}\text { Plot size } \\
\left(\mathrm{m}^{2}\right)\end{array}$ & $\begin{array}{c}\text { Tree } \\
\text { diversity } \\
\text { level }\end{array}$ & $\begin{array}{c}\text { Remaining } \\
\text { oil palms }\end{array}$ & $\begin{array}{l}\text { Thinned } \\
\text { oil palms }\end{array}$ & $\begin{array}{c}\text { Height at } \\
\text { meristem of } \\
\text { remaining oil } \\
\text { palm in } 2017\end{array}$ & $\begin{array}{l}\text { Living trees } \\
\text { in } 2016\end{array}$ & $\begin{array}{l}\text { Living trees } \\
\text { in } 2017\end{array}$ & $\begin{array}{c}\text { Dead trees } \\
\text { between } \\
2016 \text { and } \\
2017\end{array}$ \\
\hline 1 & 1600 & 1 & 13 & 7 & $5.20 \pm 0.70$ & 387 & 378 & 9 \\
\hline 2 & 400 & 3 & 1 & 3 & $4.60 \pm 0.00$ & 57 & 46 & 11 \\
\hline 3 & 400 & 2 & 2 & 3 & $5.65 \pm 0.21$ & 49 & 42 & 7 \\
\hline 4 & 100 & 1 & 0 & 1 & not applicable & 11 & 2 & 9 \\
\hline 5 & 1600 & 1 & 12 & 8 & $5.08 \pm 0.78$ & 376 & 367 & 9 \\
\hline 6 & 25 & 1 & 0 & 0 & not applicable & 6 & 6 & 0 \\
\hline 7 & 1600 & 3 & 11 & 8 & $4.64 \pm 0.54$ & 279 & 220 & 59 \\
\hline 8 & 25 & 1 & 0 & 0 & not applicable & 1 & 0 & 1 \\
\hline 9 & 100 & 3 & 1 & 1 & $5.70 \pm 0.00$ & 18 & 18 & 0 \\
\hline 10 & 400 & 0 & 1 & 3 & $4.90 \pm 0.00$ & 0 & 0 & 0 \\
\hline 11 & 100 & 1 & 0 & 1 & not available & 1 & 1 & 0 \\
\hline 12 & 400 & 1 & 2 & 1 & $4.65 \pm 0.78$ & 21 & 15 & 6 \\
\hline 13 & 100 & 1 & 0 & 1 & not applicable & 25 & 25 & 0 \\
\hline 14 & 100 & 1 & 0 & 1 & not applicable & 7 & 7 & 0 \\
\hline 15 & 400 & 1 & 2 & 2 & $4.75 \pm 0.07$ & 100 & 100 & 0 \\
\hline 16 & 25 & 3 & 0 & 0 & not applicable & 3 & 2 & 1 \\
\hline 17 & 400 & 1 & 2 & 3 & $6.00 \pm 0.14$ & 67 & 40 & 27 \\
\hline 18 & 25 & 2 & 0 & 0 & not applicable & 3 & 3 & 0 \\
\hline 19 & 400 & 6 & 3 & 2 & $3.80 \pm 0.61$ & 54 & 48 & 6 \\
\hline 20 & 100 & 1 & 1 & 1 & $5.90 \pm 0.00$ & 23 & 19 & 4 \\
\hline 21 & 100 & 6 & 0 & 1 & not applicable & 18 & 15 & 3 \\
\hline 22 & 25 & 2 & 0 & 0 & not applicable & 3 & 3 & 0 \\
\hline 23 & 1600 & 6 & 12 & 8 & $5.32 \pm 0.45$ & 254 & 222 & 32 \\
\hline 24 & 1600 & 2 & 11 & 6 & $5.81 \pm 1.15$ & 215 & 201 & 14 \\
\hline 25 & 25 & 1 & 0 & 0 & not applicable & 6 & 5 & 1 \\
\hline 26 & 1600 & 2 & 12 & 6 & $6.01 \pm 0.62$ & 45 & 12 & 33 \\
\hline 27 & 100 & 2 & 0 & 1 & not applicable & 24 & 23 & 1 \\
\hline 28 & 25 & 1 & 0 & 0 & not applicable & 6 & 6 & 0 \\
\hline 29 & 1600 & 3 & 20 & 8 & $5.54 \pm 0.92$ & 184 & 166 & 18 \\
\hline
\end{tabular}


Appendix Table 1. (Cont.) Summary table of plot information and recorded trees in 2016 and 2017

\begin{tabular}{|c|c|c|c|c|c|c|c|c|}
\hline $\begin{array}{l}\text { Plot } \\
\text { ID }\end{array}$ & $\begin{array}{l}\text { Plot size } \\
\qquad\left(\mathrm{m}^{2}\right)\end{array}$ & $\begin{array}{c}\text { Tree } \\
\text { diversity } \\
\text { level }\end{array}$ & $\begin{array}{c}\text { Remaining } \\
\text { oil palms }\end{array}$ & $\begin{array}{l}\text { Thinned } \\
\text { oil palms }\end{array}$ & $\begin{array}{c}\text { Height at } \\
\text { meristem of } \\
\text { remaining oil } \\
\text { palm in } 2017\end{array}$ & $\begin{array}{l}\text { Living trees } \\
\text { in } 2016\end{array}$ & $\begin{array}{l}\text { Living trees } \\
\text { in } 2017\end{array}$ & $\begin{array}{c}\text { Dead trees } \\
\text { between } \\
2016 \text { and } \\
2017\end{array}$ \\
\hline 30 & 400 & 1 & 2 & 2 & $6.10 \pm 0.99$ & 100 & 100 & 0 \\
\hline 31 & 25 & 1 & 0 & 0 & not applicable & 5 & 4 & 1 \\
\hline 32 & 100 & 2 & 1 & 1 & $5.40 \pm 0.00$ & 5 & 3 & 2 \\
\hline 33 & 400 & 3 & 4 & 3 & $7.00 \pm 0.37$ & 68 & 67 & 1 \\
\hline 34 & 100 & 2 & 1 & 1 & $5.30 \pm 0.00$ & 11 & 11 & 0 \\
\hline 35 & 1600 & 0 & 16 & 5 & $5.25 \pm 0.48$ & 0 & 0 & 0 \\
\hline 36 & 400 & 2 & 1 & 3 & $5.70 \pm 0.00$ & 54 & 51 & 3 \\
\hline 37 & 100 & 0 & 1 & 1 & $4.30 \pm 0.00$ & 0 & 0 & 0 \\
\hline 38 & 400 & 1 & 3 & 4 & $5.93 \pm 0.57$ & 47 & 44 & 3 \\
\hline 39 & 25 & 2 & 0 & 0 & not applicable & 4 & 3 & 1 \\
\hline 40 & 25 & 0 & 0 & 0 & not applicable & 0 & 0 & 0 \\
\hline 41 & 100 & 1 & 0 & 1 & not applicable & 22 & 22 & 0 \\
\hline 42 & 25 & 1 & 0 & 0 & not applicable & 5 & 5 & 0 \\
\hline 43 & 1600 & 1 & 11 & 7 & $5.89 \pm 0.78$ & 141 & 75 & 66 \\
\hline 44 & 25 & 3 & 0 & 0 & not applicable & 3 & 3 & 0 \\
\hline 45 & 1600 & 1 & 14 & 4 & $4.76 \pm 0.85$ & 396 & 379 & 17 \\
\hline 46 & 1600 & 2 & 17 & 8 & $4.69 \pm 0.95$ & 351 & 270 & 81 \\
\hline 47 & 400 & 2 & 5 & 1 & $6.06 \pm 0.58$ & 96 & 86 & 10 \\
\hline 48 & 100 & 3 & 0 & 1 & not applicable & 18 & 17 & 1 \\
\hline 49 & 1600 & 1 & 15 & 5 & $5.39 \pm 0.64$ & 136 & 71 & 65 \\
\hline 50 & 25 & 6 & 0 & 0 & not applicable & 5 & 3 & 2 \\
\hline 51 & 400 & 1 & 3 & 2 & $6.50 \pm 0.35$ & 95 & 94 & 1 \\
\hline 52 & 1600 & 1 & 13 & 7 & $5.59 \pm 1.09$ & 14 & 12 & 2 \\
\hline 53 & 100 & control & 1 & 0 & $3.60 \pm 0.00$ & 0 & 0 & 0 \\
\hline 54 & 100 & control & 1 & 0 & $5.90 \pm 0.00$ & 0 & 0 & 0 \\
\hline 55 & 100 & control & 1 & 0 & $5.80 \pm 0.00$ & 0 & 0 & 0 \\
\hline 56 & 100 & control & 1 & 0 & $5.60 \pm 0.00$ & 0 & 0 & 0 \\
\hline
\end{tabular}


Appendix Table 2. Summary of drone multi-plot assessment.

\begin{tabular}{|c|c|c|c|c|c|c|c|c|c|c|c|c|c|c|}
\hline $\begin{array}{l}\text { Plot } \\
\text { ID }\end{array}$ & Location & $\begin{array}{c}\text { Image } \\
\text { acquired } \\
\text { date } \\
\end{array}$ & $\begin{array}{c}\text { Circular } \\
\text { flight radii } \\
\text { (m) }\end{array}$ & $\begin{array}{l}\text { Grid flight } \\
\text { lines (n) }\end{array}$ & $\begin{array}{c}\text { Number of } \\
\text { images }\end{array}$ & $\begin{array}{c}\text { Error of ground } \\
\text { control points in } \\
\text { XYZ (m) } \\
\end{array}$ & $\begin{array}{l}\text { Point density } \\
\text { (points } / \mathrm{m}^{2} \text { ) }\end{array}$ & $\underset{(\mathrm{m})}{\mathrm{CHM}}$ & $\begin{array}{c}\text { Plot canopy } \\
\text { cover }(\%)\end{array}$ & $\begin{array}{c}\text { Oil Palm } \\
\text { canopy cover } \\
(\%) \\
\end{array}$ & $\begin{array}{c}\text { Tree } \\
\text { canopy } \\
\text { cover (\%) } \\
\end{array}$ & \begin{tabular}{|c|}
$\begin{array}{c}\text { Validated } \\
\text { buffer area } \\
\left(\mathrm{m}^{2}\right)\end{array}$ \\
\end{tabular} & $\begin{array}{c}\text { Canopy cover } \\
\text { ground- based } \\
(\%) \\
\end{array}$ & $\begin{array}{c}\text { Canopy cover } \\
\text { drone-based } \\
(\%) \\
\end{array}$ \\
\hline 1 & $\begin{array}{r}\text { S 1 1 } 56^{\prime} 29.36^{\prime \prime} \\
\text { E } 103^{\circ} 15^{\prime} 7.70^{\prime \prime} \\
\end{array}$ & 26.09 .2016 & 35,40 & 10 & 999 & 2.06 & 3650 & 3.11 & 70.87 & 45.59 & 23.89 & 2.99 & 77.50 & 72.58 \\
\hline 2 & $\begin{array}{c}\mathrm{S} 1^{\circ} 56^{\prime} 30.00^{\prime \prime} \\
\text { E } 103^{\circ} 15^{\prime} 10.99^{\prime \prime}\end{array}$ & 26.09 .2016 & 30,35 & 7 & 764 & 1.42 & 748 & 4.01 & 57.34 & 45.54 & 12.20 & 0.54 & 0.10 & 0.00 \\
\hline 3 & $\begin{array}{l}\mathrm{S} 1^{\circ} 56^{\prime} 35.79^{\prime \prime} \\
\text { E } 103^{\circ} 15^{\prime} 6.64^{\prime \prime} \\
\end{array}$ & 01.10 .2016 & 30,35 & 7 & 684 & 0.92 & 4800 & 4.73 & 58.59 & 54.18 & 4.74 & 2.60 & 4.60 & 0.05 \\
\hline 4 & $\begin{array}{c}\mathrm{S} 1^{\circ} 56^{\prime} 35.38^{\prime \prime} \\
\text { E } 103^{\circ} 15^{\prime} 11.68^{\prime \prime} \\
\end{array}$ & 02.10 .2016 & 27,32 & 6 & 677 & 0.01 & 1820 & 3.65 & 66.79 & 64.16 & 4.06 & 4.35 & 4.60 & 10.52 \\
\hline 5 & $\begin{array}{r}\mathrm{S} 1^{\circ} 56^{\prime} 40.91^{\prime \prime} \\
\text { E } 103^{\circ} 15^{\prime} 7.05^{\prime \prime} \\
\end{array}$ & 04.10 .2016 & 35,40 & 10 & 910 & 3.18 & 3280 & 4.78 & 81.10 & 54.42 & 26.50 & 1.33 & 82.10 & 77.67 \\
\hline 6 & $\begin{array}{c}\mathrm{S} 1^{\circ} 56^{\prime} 40.51^{\prime \prime} \\
\text { E } 103^{\circ} 15^{\prime} 11.31^{\prime \prime} \\
\end{array}$ & 04.10 .2016 & 26,31 & 5 & 523 & 0.17 & 3080 & 10.38 & 94.19 & 94.44 & 0.00 & 34.62 & 97.00 & 94.24 \\
\hline 7 & $\begin{array}{c}\mathrm{S} 1^{\circ} 56^{\prime} 40.19^{\prime \prime} \\
\text { E } 103^{\circ} 15^{\prime} 19.08^{\prime \prime} \\
\end{array}$ & 04.10 .2016 & 35,40 & 10 & 944 & 0.78 & 1570 & 8.10 & 67.96 & 36.19 & 30.33 & 15.05 & 92.90 & 63.81 \\
\hline 8 & $\begin{array}{c}\text { S } 1^{\circ} 56^{\prime} 44.99^{\prime \prime} \\
\text { E 103 } 13^{\circ} 14^{\prime} 56.81^{\prime \prime}\end{array}$ & 05.10 .2016 & 26,31 & 5 & 488 & 0.00 & 2260 & 6.68 & 73.00 & 72.68 & 0.00 & 19.87 & 85.80 & 76.99 \\
\hline 9 & $\begin{array}{l}\text { S 1 1 } 56^{\prime} 44.69^{\prime \prime} \\
\text { E } 103^{\circ} 15^{\prime} 2.35^{\prime \prime}\end{array}$ & 05.10 .2016 & 27,32 & 6 & 613 & 0.03 & 1510 & 11.12 & 88.31 & 63.57 & 25.04 & 37.10 & 32.90 & 44.78 \\
\hline 10 & $\begin{array}{r}\text { S 1 } 1^{\circ} 56^{\prime} 44.95^{\prime \prime} \\
\text { E } 103^{\circ} 15^{\prime} 6.88^{\prime \prime} \\
\end{array}$ & 04.10 .2016 & 30,35 & 7 & 663 & 0.68 & 1830 & 3.07 & 40.43 & 38.81 & 2.10 & 1.80 & 77.50 & 68.73 \\
\hline 11 & $\begin{array}{c}\mathrm{S} 1^{\circ} 56^{\prime} 45.28^{\prime \prime} \\
\text { E } 103^{\circ} 15^{\prime} 11.58^{\prime \prime} \\
\end{array}$ & 06.10 .2016 & 37,32 & 6 & 730 & 0.05 & 1710 & 8.99 & 68.16 & 63.06 & 4.66 & 24.68 & 84.30 & 67.34 \\
\hline 12 & $\begin{array}{r}\mathrm{S} 1^{\circ} 56^{\prime} 44.87^{\prime \prime} \\
\text { E } 103^{\circ} 15^{\prime} 15.88^{\prime \prime} \\
\end{array}$ & 06.10 .2016 & 30,35 & 7 & 745 & 1.56 & 1870 & 7.92 & 58.14 & 42.99 & 14.44 & 19.31 & 22.70 & 50.00 \\
\hline 13 & $\begin{array}{c}\text { S } 1^{\circ} 56^{\prime} 45.22^{\prime \prime} \\
\text { E } 103^{\circ} 15^{\prime} 21.42^{\prime \prime} \\
\end{array}$ & 06.10 .2016 & 27,32 & 6 & 645 & 0.01 & 2360 & 6.02 & 55.93 & 10.47 & 45.67 & 9.97 & 60.30 & 61.45 \\
\hline 14 & $\begin{array}{c}\text { S } 1^{\circ} 56^{\prime} 50.01^{\prime \prime} \\
\text { E } 103^{\circ} 14^{\prime} 57.07^{\prime \prime}\end{array}$ & 06.10 .2016 & 27,32 & 6 & 616 & 0.09 & 2350 & 4.54 & 51.87 & 49.93 & 3.52 & 5.12 & 15.40 & 4.33 \\
\hline
\end{tabular}


Appendix Table 2. (Cont.) Summary of drone multi-plot assessment.

\begin{tabular}{|c|c|c|c|c|c|c|c|c|c|c|c|c|c|c|}
\hline $\begin{array}{l}\text { Plot } \\
\text { ID }\end{array}$ & Location & $\begin{array}{c}\text { Image } \\
\text { acquired } \\
\text { date } \\
\end{array}$ & $\begin{array}{c}\text { Circular } \\
\text { flight radii } \\
(\mathrm{m})\end{array}$ & $\begin{array}{l}\text { Grid flight } \\
\text { lines (n) }\end{array}$ & $\begin{array}{c}\text { Number of } \\
\text { images }\end{array}$ & $\begin{array}{c}\text { Error of ground } \\
\text { control points in } \\
\text { XYZ }(\mathrm{m})\end{array}$ & $\begin{array}{c}\text { Point density } \\
\text { (points } / \mathrm{m}^{2} \text { ) }\end{array}$ & $\underset{(\mathrm{m})}{\mathrm{CHM}}$ & $\begin{array}{c}\text { Plot canopy } \\
\text { cover }(\%)\end{array}$ & $\begin{array}{c}\text { Oil Palm } \\
\text { canopy cover } \\
(\%) \\
\end{array}$ & $\begin{array}{c}\text { Tree } \\
\text { canopy } \\
\text { cover }(\%) \\
\end{array}$ & \begin{tabular}{|c|}
$\begin{array}{c}\text { Validated } \\
\text { buffer area } \\
\left(\mathrm{m}^{2}\right)\end{array}$ \\
\end{tabular} & $\begin{array}{c}\text { Canopy cover } \\
\text { ground- based } \\
(\%) \\
\end{array}$ & $\begin{array}{c}\text { Canopy cover } \\
\text { drone-based } \\
(\%)\end{array}$ \\
\hline 15 & $\begin{array}{l}\text { S 1 1 } 56^{\prime} 49.50^{\prime \prime} \\
\text { E } 103^{\circ} 15^{\prime} 1.85^{\prime \prime} \\
\end{array}$ & 06.10 .2016 & 30,35 & 7 & 655 & 1.31 & 3190 & 3.16 & 74.98 & 46.68 & 27.87 & 1.72 & 88.30 & 85.39 \\
\hline 16 & $\begin{array}{l}\text { S } 1^{\circ} 56^{\prime} 50.31 " \\
\text { E } 103^{\circ} 15^{\prime} 6.91^{\prime \prime}\end{array}$ & 06.10 .2016 & 26,31 & 5 & 599 & 0.00 & 2830 & 7.13 & 69.36 & 54.85 & 14.71 & 27.90 & 79.40 & 75.04 \\
\hline 17 & $\begin{array}{c}\mathrm{S} 1^{\circ} 56^{\prime} 50.15^{\prime \prime} \\
\mathrm{E} 103^{\circ} 15^{\prime} 11.64^{\prime \prime}\end{array}$ & 07.10 .2016 & 30,35 & 7 & 681 & 1.01 & 1110 & 4.21 & 68.91 & 49.71 & 20.80 & 5.28 & 83.20 & 80.63 \\
\hline 18 & $\begin{array}{c}\text { S } 1^{\circ} 56^{\prime} 49.72^{\prime \prime} \\
\text { E } 103^{\circ} 15^{\prime} 16.30^{\prime \prime}\end{array}$ & 07.10 .2016 & 26,31 & 5 & 454 & 0.00 & 2560 & 3.38 & 80.17 & 80.30 & 0.00 & 6.02 & 91.60 & 83.89 \\
\hline 19 & $\begin{array}{c}\text { S } 1^{\circ} 56^{\prime} 50.30^{\prime \prime} \\
\text { E } 103^{\circ} 15^{\prime} 21.31^{\prime \prime}\end{array}$ & 07.10 .2016 & 30,35 & 7 & 722 & 0.35 & 1850 & 7.49 & 63.61 & 27.40 & 34.17 & 16.96 & 77.20 & 73.17 \\
\hline 20 & $\begin{array}{l}\text { S } 1^{\circ} 56^{\prime} 50.3124^{\prime \prime} \\
\text { E } 103^{\circ} 15^{\prime} 26.44^{\prime \prime}\end{array}$ & 07.10 .2016 & 27,32 & 6 & 577 & 0.04 & 2950 & 4.09 & 57.08 & 45.85 & 11.43 & 5.88 & 69.50 & 72.21 \\
\hline 21 & $\begin{array}{c}\mathrm{S} 1^{\circ} 56^{\prime} 54.84^{\prime \prime} \\
\text { E } 103^{\circ} 14^{\prime} 52.33^{\prime \prime}\end{array}$ & 07.10 .2016 & 27,32 & 6 & 617 & 0.07 & 2570 & 4.21 & 66.72 & 46.48 & 20.67 & 4.70 & 70.10 & 53.95 \\
\hline 22 & $\begin{array}{c}\mathrm{S} 1^{\circ} 56^{\prime} 55.10^{\prime \prime} \\
\text { E } 103^{\circ} 14^{\prime} 57.15^{\prime \prime}\end{array}$ & 07.10 .2016 & 26,31 & 5 & 527 & 0.00 & 3420 & 6.59 & 70.66 & 70.33 & 0.00 & 22.12 & 76.10 & 72.50 \\
\hline 23 & $\begin{array}{c}\text { S } 1^{\circ} 56^{\prime} 55.26^{\prime \prime} \\
\text { E } 103^{\circ} 15^{\prime} 5.42^{\prime \prime}\end{array}$ & 10.10 .2016 & 35,40 & 10 & 978 & 0.83 & 10000 & 6.13 & 78.09 & 53.55 & 24.01 & 20.78 & 84.40 & 79.72 \\
\hline 24 & $\begin{array}{c}\mathrm{S} 1^{\circ} 56^{\prime} 53.77^{\prime \prime} \\
\text { E } 103^{\circ} 15^{\prime} 16.09^{\prime \prime}\end{array}$ & 07.10 .2016 & 35,40 & 10 & 936 & 2.70 & 1900 & 3.61 & 71.61 & 44.68 & 26.95 & 4.10 & 66.80 & 53.96 \\
\hline 25 & $\begin{array}{c}\mathrm{S} 1^{\circ} 56^{\prime} 55.09^{\prime \prime} \\
\text { E } 103^{\circ} 15^{\prime} 21.31^{\prime \prime}\end{array}$ & 08.10 .2016 & 26,31 & 5 & 415 & 0.00 & 4020 & 3.07 & 84.04 & 58.04 & 25.98 & 2.88 & 87.50 & 78.69 \\
\hline 26 & $\begin{array}{c}\mathrm{S} 1^{\circ} 56^{\prime} 53.70^{\prime \prime} \\
\text { E } 103^{\circ} 15^{\prime} 26.64^{\prime \prime}\end{array}$ & 08.10 .2016 & 35,40 & 10 & 999 & 1.44 & 2640 & 4.68 & 55.79 & 54.50 & 2.24 & 8.58 & 82.00 & 65.32 \\
\hline 27 & $\begin{array}{c}\text { S } 1^{\circ} 56^{\prime} 59.36^{\prime \prime} \\
\text { E } 103^{\circ} 14^{\prime} 47.33^{\prime \prime}\end{array}$ & 08.10 .2016 & 27,32 & 6 & 718 & 0.22 & 2750 & 3.79 & 72.16 & 16.75 & 54.82 & 3.15 & 82.90 & 87.93 \\
\hline 28 & $\begin{array}{c}\text { S } 1^{\circ} 56^{\prime} 59.88^{\prime \prime} \\
\text { E } 103^{\circ} 14^{\prime} 52.30^{\prime \prime}\end{array}$ & 08.10 .2016 & 26,31 & 5 & 600 & 0.00 & 3140 & 8.28 & 92.85 & 94.33 & 0.00 & 19.64 & 98.80 & 93.86 \\
\hline 29 & $\begin{array}{l}\text { S } 1^{\circ} 56^{\prime} 59.21^{\prime \prime} \\
\text { E } 103^{\circ} 14^{\prime} 57.03^{\prime \prime}\end{array}$ & 08.10 .2016 & 35,40 & 10 & 994 & 2.95 & 2190 & 4.76 & 78.33 & 69.10 & 9.56 & 8.07 & 79.40 & 75.92 \\
\hline
\end{tabular}


Appendix Table 2. (Cont.) Summary of drone multi-plot assessment.

\begin{tabular}{|c|c|c|c|c|c|c|c|c|c|c|c|c|c|c|}
\hline $\begin{array}{l}\text { Plot } \\
\text { ID }\end{array}$ & Location & $\begin{array}{c}\text { Image } \\
\text { acquired } \\
\text { date }\end{array}$ & $\begin{array}{l}\text { Circular } \\
\text { flight radii } \\
\text { (m) }\end{array}$ & $\begin{array}{l}\text { Grid flight } \\
\text { lines (n) }\end{array}$ & $\begin{array}{c}\text { Number of } \\
\text { images }\end{array}$ & $\begin{array}{c}\text { Error of ground } \\
\text { control points in } \\
\text { XYZ }(\mathrm{m})\end{array}$ & $\begin{array}{l}\text { Point density } \\
\text { (points } / \mathrm{m}^{2} \text { ) }\end{array}$ & $\begin{array}{l}\mathrm{CHM} \\
(\mathrm{m})\end{array}$ & $\begin{array}{l}\text { Plot canopy } \\
\text { cover }(\%)\end{array}$ & $\begin{array}{c}\text { Oil Palm } \\
\text { canopy cover } \\
(\%)\end{array}$ & $\begin{array}{c}\text { Tree } \\
\text { canopy } \\
\text { cover (\%) }\end{array}$ & \begin{tabular}{|c|}
$\begin{array}{c}\text { Validated } \\
\text { buffer area } \\
\left(\mathrm{m}^{2}\right)\end{array}$ \\
\end{tabular} & $\begin{array}{c}\text { Canopy cover } \\
\text { ground- based } \\
(\%)\end{array}$ & $\begin{array}{c}\text { Canopy cover } \\
\text { drone-based } \\
(\%) \\
\end{array}$ \\
\hline 30 & $\begin{array}{c}\text { S } 1^{\circ} 56^{\prime} 58.91^{\prime \prime} \\
\text { E } 103^{\circ} 15^{\prime} 11.03^{\prime \prime}\end{array}$ & 08.10 .2016 & 30,35 & 7 & 729 & 1.53 & 3510 & 2.59 & 58.28 & 42.16 & 14.96 & 0.97 & 81.90 & 79.80 \\
\hline 31 & $\begin{array}{c}\text { S } 1^{\circ} 56^{\prime} 59.77^{\prime \prime} \\
\text { E } 103^{\circ} 15^{\prime} 16.27^{\prime \prime}\end{array}$ & 09.10 .2016 & 26,31 & 5 & 561 & 0.00 & 2220 & 4.83 & 87.28 & 87.13 & 0.00 & 12.04 & 76.60 & 88.79 \\
\hline 32 & $\begin{array}{c}\text { S 1 1 } 56^{\prime} 59.83^{\prime \prime} \\
\text { E } 103^{\circ} 15^{\prime} 21.33^{\prime \prime} \\
\end{array}$ & 09.10 .2016 & 27,32 & 6 & 584 & 0.05 & 4090 & 3.45 & 58.59 & 57.18 & 2.61 & 3.37 & 41.90 & 58.26 \\
\hline 33 & $\begin{array}{c}\text { S } 1^{\circ} 56^{\prime} 59.66^{\prime \prime} \\
\text { E } 103^{\circ} 15^{\prime} 26.19^{\prime \prime} \\
\end{array}$ & 09.10 .2016 & 30,35 & 7 & 788 & 1.54 & 1950 & 3.77 & 71.94 & 55.35 & 16.36 & 4.36 & 67.50 & 73.37 \\
\hline 34 & $\begin{array}{c}\mathrm{S} 1^{\circ} 57^{\prime} 4.90^{\prime \prime} \\
\text { E } 103^{\circ} 14^{\prime} 42.45^{\prime \prime}\end{array}$ & 11.10 .2016 & 27,32 & 6 & 602 & 0.06 & 2220 & 4.04 & 59.26 & 40.70 & 18.61 & 5.60 & 45.20 & 58.03 \\
\hline 35 & $\begin{array}{c}\text { S } 1^{\circ} 57^{\prime} 5.65^{\prime \prime} \\
\text { E } 103^{\circ} 14^{\prime} 47.93^{\prime \prime}\end{array}$ & 09.10 .2016 & 35,40 & 10 & 960 & 0.65 & 2180 & 3.53 & 65.17 & 59.04 & 5.98 & 4.97 & 96.10 & 95.43 \\
\hline 36 & $\begin{array}{c}\text { S } 1^{\circ} 57^{\prime} 3.34^{\prime \prime} \\
\text { E } 103^{\circ} 14^{\prime} 52.10^{\prime \prime} \\
\end{array}$ & 10.10 .2016 & 30,35 & 7 & 713 & 2.55 & 2300 & 4.15 & 64.83 & 43.64 & 21.60 & 3.33 & 14.10 & 18.54 \\
\hline 37 & $\begin{array}{c}\text { S 1 1 } 57^{\prime} 4.15^{\prime \prime} \\
\text { E } 103^{\circ} 14^{\prime} 55.94^{\prime \prime} \\
\end{array}$ & 10.10 .2016 & 27,32 & 6 & 608 & 0.01 & 2350 & 4.57 & 74.03 & 72.92 & 0.89 & 6.73 & 95.40 & 90.35 \\
\hline 38 & $\begin{array}{c}\text { S } 1^{\circ} 57^{\prime} 5.74^{\prime \prime} \\
\text { E } 103^{\circ} 15^{\prime} 1.95^{\prime \prime} \\
\end{array}$ & 10.10 .2016 & 30,35 & 7 & 680 & 1.09 & 2570 & 5.07 & 65.75 & 47.90 & 16.06 & 14.18 & 84.60 & 86.96 \\
\hline 39 & $\begin{array}{c}\mathrm{S} 1^{\circ} 57^{\prime} 4.19^{\prime \prime} \\
\text { E } 103^{\circ} 15^{\prime} 6.31^{\prime \prime}\end{array}$ & 10.10 .2016 & 26,31 & 5 & 642 & 0.00 & 2960 & 2.64 & 62.22 & 57.86 & 4.45 & 3.95 & 75.50 & 75.85 \\
\hline 40 & $\begin{array}{c}\text { S } 1^{\circ} 57^{\prime} 4.83^{\prime \prime} \\
\text { E } 103^{\circ} 15^{\prime} 25.86^{\prime \prime} \\
\end{array}$ & 09.10 .2016 & 26,31 & 5 & 555 & 0.00 & 2160 & 4.05 & 85.32 & 85.85 & 0.00 & 7.84 & 90.30 & 86.05 \\
\hline 41 & $\begin{array}{c}\text { S } 1^{\circ} 57^{\prime} 9.55^{\prime \prime} \\
\text { E } 103^{\circ} 14^{\prime} 37.80^{\prime \prime}\end{array}$ & 11.10 .2016 & 27,32 & 6 & 658 & 0.09 & 2780 & 3.14 & 54.17 & 44.47 & 9.51 & 4.02 & 24.50 & 26.88 \\
\hline 42 & $\begin{array}{c}\mathrm{S} 1^{\circ} 57^{\prime} 9.85^{\prime \prime} \\
\text { E } 103^{\circ} 14^{\prime} 42.05^{\prime \prime} \\
\end{array}$ & 11.10 .2016 & 26,31 & 5 & 544 & 0.00 & 2890 & 9.73 & 93.17 & 93.23 & 0.00 & 26.24 & 83.40 & 93.02 \\
\hline 43 & $\begin{array}{l}\text { S } 1^{\circ} 56^{\prime} 57.77^{\prime \prime} \\
\text { E } 103^{\circ} 15^{\prime} 31.59^{\prime \prime}\end{array}$ & 09.10 .2016 & 35,40 & 10 & 862 & 1.35 & 2800 & 4.88 & 62.01 & 58.92 & 1.89 & 3.27 & 9.70 & 6.14 \\
\hline 44 & $\begin{array}{c}\text { S } 1^{\circ} 57^{\prime} 9.53^{\prime \prime} \\
\text { E } 103^{\circ} 14^{\prime} 52.32^{\prime \prime} \\
\end{array}$ & 11.10 .2016 & 26,31 & 5 & 609 & 0.00 & 2550 & 3.86 & 78.80 & 64.70 & 12.91 & 6.37 & 86.70 & 88.00 \\
\hline
\end{tabular}




\section{Appendix Table 2. (Cont.) Summary of drone multi-plot assessment}

\begin{tabular}{|c|c|c|c|c|c|c|c|c|c|c|c|c|c|c|}
\hline $\begin{array}{l}\text { Plot } \\
\text { ID }\end{array}$ & Location & $\begin{array}{c}\text { Image } \\
\text { acquired date }\end{array}$ & $\begin{array}{c}\text { Circular } \\
\text { flight radii } \\
\text { (m) }\end{array}$ & $\begin{array}{l}\text { Grid flight } \\
\text { lines (n) }\end{array}$ & $\begin{array}{c}\text { Number of } \\
\text { images }\end{array}$ & $\begin{array}{l}\text { Error of ground } \\
\text { control points in } \\
\text { XYZ (m) } \\
\end{array}$ & $\begin{array}{l}\text { Point density } \\
\text { (points } / \mathrm{m}^{2} \text { ) }\end{array}$ & $\begin{array}{l}\text { CHM } \\
(\mathrm{m})\end{array}$ & $\begin{array}{c}\text { Plot canopy } \\
\text { cover }(\%)\end{array}$ & $\begin{array}{c}\text { Oil Palm } \\
\text { canopy cover } \\
(\%) \\
\end{array}$ & $\begin{array}{c}\text { Tree } \\
\text { canopy } \\
\text { cover }(\%)\end{array}$ & $\begin{array}{c}\text { Validated } \\
\text { buffer area } \\
\left(\mathrm{m}^{2}\right)\end{array}$ & $\begin{array}{c}\text { Canopy cover } \\
\text { ground- based } \\
(\%)\end{array}$ & $\begin{array}{c}\text { Canopy cover } \\
\text { drone-based } \\
(\%)\end{array}$ \\
\hline 45 & $\begin{array}{l}\mathrm{S} 1^{\circ} 57^{\prime} 10.22^{\prime \prime} \\
\text { E } 103^{\circ} 14^{\prime} 56.02^{\prime \prime}\end{array}$ & 10.10 .2016 & 35,40 & 10 & 955 & 2.58 & 1890 & 3.11 & 67.56 & 42.82 & 24.48 & 5.71 & 76.20 & 72.04 \\
\hline 46 & $\begin{array}{c}\text { S 1 }{ }^{\circ} 57^{\prime} 15.24^{\prime \prime} \\
\text { E } 103^{\circ} 14^{\prime} 33.37^{\prime \prime}\end{array}$ & 11.10 .2016 & 35,40 & 10 & 853 & 3.92 & 2380 & 3.57 & 73.17 & 60.43 & 12.23 & 3.55 & 14.50 & 34.57 \\
\hline 47 & $\begin{array}{c}\text { S } 1^{\circ} 57^{\prime} 13.55^{\prime \prime} \\
\text { E } 103^{\circ} 14^{\prime} 37.77^{\prime \prime}\end{array}$ & 11.10 .2016 & 30,35 & 7 & 659 & 3.99 & 3260 & 4.90 & 81.24 & 72.86 & 8.50 & 3.37 & 14.90 & 42.68 \\
\hline 48 & $\begin{array}{c}\text { S } 1^{\circ} 57^{\prime} 14.59^{\prime \prime} \\
\text { E } 103^{\circ} 14^{\prime} 42.84^{\prime \prime}\end{array}$ & 12.10 .2016 & 27,32 & 6 & 601 & 0.04 & 3290 & 4.51 & 77.11 & 65.32 & 11.74 & 6.04 & 30.90 & 56.32 \\
\hline 49 & $\begin{array}{c}\mathrm{S} 1^{\circ} 57^{\prime} 13.94^{\prime \prime} \\
\text { E } 103^{\circ} 14^{\prime} 47.77^{\prime \prime}\end{array}$ & 12.10 .2016 & 35,40 & 10 & 960 & 2.25 & 1900 & 3.76 & 55.06 & 46.73 & 8.81 & 1.80 & 5.50 & 10.07 \\
\hline 50 & $\begin{array}{c}\text { S } 1^{\circ} 57^{\prime} 14.63^{\prime \prime} \\
\text { E } 103^{\circ} 14^{\prime} 52.34^{\prime \prime}\end{array}$ & 12.10 .2016 & 26,31 & 5 & 581 & 0.00 & 2520 & 4.85 & 87.52 & 72.58 & 13.42 & 8.16 & 95.00 & 90.49 \\
\hline 51 & $\begin{array}{c}\mathrm{S} 1^{\circ} 57^{\prime} 14.81^{\prime \prime} \\
\text { E } 103^{\circ} 14^{\prime} 57.24^{\prime \prime}\end{array}$ & 12.10 .2016 & 30,35 & 7 & 661 & 0.68 & 3410 & 4.19 & 79.49 & 54.42 & 25.09 & 2.66 & 77.10 & 83.73 \\
\hline 52 & $\begin{array}{c}\text { S } 1^{\circ} 57^{\prime} 17.93^{\prime \prime} \\
\text { E } 103^{\circ} 14^{\prime} 37.07^{\prime \prime}\end{array}$ & 12.10 .2016 & 35,40 & 10 & 982 & 1.39 & 2360 & 4.52 & 62.14 & 55.75 & 6.27 & 11.04 & 76.40 & 80.55 \\
\hline 53 & $\begin{array}{c}\text { S } 1^{\circ} 56^{\prime} 34.30^{\prime \prime} \\
\text { E } 103^{\circ} 15^{\prime} 17.54^{\prime \prime}\end{array}$ & 12.10.2016 & 27,32 & 6 & 613 & 0.00 & 2390 & 3.82 & 79.15 & 79.13 & 0.00 & 5.00 & 88.60 & 76.92 \\
\hline 54 & $\begin{array}{c}\text { S } 1^{\circ} 57^{\prime} 4.22^{\prime \prime} \\
\text { E } 103^{\circ} 15^{\prime} 20.82^{\prime \prime}\end{array}$ & 13.10 .2016 & 27,32 & 6 & 531 & 0.00 & 3850 & 5.33 & 87.15 & 87.28 & 0.00 & 9.08 & 75.40 & 87.92 \\
\hline 55 & $\begin{array}{c}\text { S } 1^{\circ} 57^{\prime} 4.73^{\prime \prime} \\
\text { E } 103^{\circ} 15^{\prime} 11.85^{\prime \prime}\end{array}$ & 13.10 .2016 & 27,32 & 6 & 637 & 0.00 & 2510 & 5.81 & 73.12 & 74.36 & 0.00 & 9.51 & 58.20 & 60.93 \\
\hline 56 & $\begin{array}{l}\text { S } 1^{\circ} 57^{\prime} 17.98^{\prime \prime} \\
\text { E } 103^{\circ} 14^{\prime} 45.83^{\prime \prime}\end{array}$ & 12.10 .2016 & 27,32 & 6 & 613 & 0.00 & 2160 & 4.13 & 70.67 & 71.01 & 0.00 & 4.94 & 11.20 & 22.43 \\
\hline
\end{tabular}


Appendix Table 3. Initial number of planted trees in December 2013, number of living trees in January 2016, and mortality of planted trees between January 2016 and January 2017 from field inventory (48 plots).

\begin{tabular}{lccc}
\hline Living trees & $\begin{array}{c}\text { Living trees } \\
\text { in } \mathbf{2 0 1 3} \\
\text { (n) }\end{array}$ & $\begin{array}{c}\text { in 2016 } \\
\text { (n) }\end{array}$ & $\begin{array}{c}\text { Mortality between } \\
\mathbf{2 0 1 6} \text { and 2017 } \\
\left(\mathbf{\%} \mathbf{~ y r}^{-\mathbf{1}}\right)\end{array}$ \\
\hline Archidendron pauciflorum & 1061 & 990 & 8 \\
Durio zibethinus & 1057 & 276 & 39 \\
Dyera polyphylla & 1061 & 129 & 7 \\
Parkia speciosa & 1057 & 978 & 9 \\
Peronema canescens & 1057 & 1031 & 3 \\
Shorea leprosula & 1061 & 415 & 47 \\
\hline
\end{tabular}

Appendix Table 4. P-values of Fisher's exact test and number of trees that died and survived between 2016 and 2017. '*' indicates the probability of mortality during the year of the study dependent on oil palm canopy cover class (two-tailed $p<0.05$, Fisher's Exact test).

\begin{tabular}{lccc}
\hline Species & $\begin{array}{r}\text { Fisher's exact test } \\
(\text { p-value })\end{array}$ & $\begin{array}{c}\text { Dead tree } \\
(\mathrm{N})\end{array}$ & $\begin{array}{c}\text { Living tree } \\
(\mathrm{N})\end{array}$ \\
\hline Archidendron pauciflorum & $0.0045^{*}$ & 76 & 914 \\
Durio zibethinus & $0.0184^{*}$ & 109 & 167 \\
Dyera polyphylla & 0.8110 & 9 & 120 \\
Parkia speciosa & 0.2976 & 84 & 894 \\
Peronema canescens & 0.5510 & 26 & 1005 \\
Shorea leprosula & $0.0005^{*}$ & 194 & 221 \\
\hline
\end{tabular}




\section{Chapter 4}

\section{Land use and its short-term changes around the oil palm agroforestry experiment}

Watit Khokthong1, Paul Magdon ${ }^{2}$, Delphine Clara Zemp ${ }^{3}$, Bambang Irawan ${ }^{4}$, Leti Sundawati ${ }^{5}$, Holger Kreft ${ }^{3,6}$, Dirk Hölscher ${ }^{1,6}$

${ }^{1}$ Tropical Silviculture and Forest Ecology, University of Goettingen, Goettingen, Germany

${ }^{2}$ Forest Inventory and Remote Sensing, University of Goettingen, Goettingen, Germany

${ }^{3}$ Biodiversity, Macroecology and Biogeography, University of Goettingen, Goettingen, Germany

${ }^{4}$ Faculty of Forestry, University of Jambi, Jambi, Indonesia

${ }^{5}$ Department of Forest Management, Faculty of Forestry, Bogor Agricultural University, Bogor, Indonesia

${ }^{6}$ Centre of Biodiversity and Sustainable Land Use, University of Goettingen, Goettingen, Germany

Correspondence: Watit Khokthong, Email: watit.khokthong@forst.uni-goettingen.de

Advanced manuscript 


\begin{abstract}
Mono-cultural and large-scale oil palm cultivation is associated with impaired ecosystem services and reduced biodiversity in many taxa. Agroforestry has been suggested as an option to restore these deficiencies, but its success will also depend on the landscape context. An oil palm agroforestry experiment was established in the lowland of Jambi, Sumatra, with the main goal of biodiversity enrichment by planting trees in oil palm plantations. The objectives of this study were to map the land cover and land use in the area surrounding this experiment, and analyze short-term changes in the landscape. A fixed-wing drone equipped with cameras (red, green, blue and near infrared) was used to survey an area of 1121 ha with the experimental plots in its center. Survey images were gathered in two consecutive years then processed using supervised classification and post-processing steps into eight land use types. In 2015, oil palm plantation covered $81 \%$ of the landscape, whereas the remaining $19 \%$ comprised bare soil (9\%), secondary forest (5\%), fallow (3\%), rubber plantation (2\%) and others (less than 1\%). From 2015 to 2016, the land cover of oil palm plantation increased 2\%, transforming from areas of bare soil (50\%), fallow (27\%), secondary forest (18\%) and rubber plantations $(15 \%)$. Oil palm occurred in large-continuous tracts while other land cover types were mainly dispersed small patches. So far, we conclude that the experimental agroforest is situated in an oil palm dominated landscape, and that the land use change of the area is effectively moving towards more oil palms.
\end{abstract}

Keywords: oil palm landscape; unmanned aerial vehicle; UAV; EFForTS-BEE; land use change 


\subsection{Introduction}

Oil palm cultivation has expanded during last decades, and this trend is likely to continue in the coming years (Wicke et al. 2011). Oil palm cultivation is highly productive and generates high economic returns (Sayer et al. 2012; Clough et al. 2016). However, the expansion of oil palm plantations is associated with biodiversity loss and impaired ecosystem functions (Koh and Wilcove 2008; Dislich et al. 2017). Worldwide, Indonesia is the country with the largest area of palm oil cultivation (FAO 2016). In Jambi province, Sumatra, Indonesia, the palm oil industry has developed through largescale monocultural oil palm plantations (Baudoin et al. 2017). Analysis of land use maps in Jambi from 1990 to 2013 displays a rapid expansion of oil palm plantations by $77 \%$, whereas the area of primary and secondary forest in Jambi decreased 35\% (Melati 2017). In 2013, oil palm plantations covered 4.9 Mha in Jambi province (Melati 2017), mainly occurring in large continuous blocks.

Land use maps are usually derived from satellite data, and with the rise in drone applications, the use of drone-based imagery is also used to produce land use maps in oil palm landscapes (Kalantar et al. 2017). Drone-equipped cameras have been widely used for landscape mapping because they provides more fine-spatial resolution images and are more cost effective and less influenced by cloud coverage than satellite photography (Pádua et al. 2017; lizuka et al. 2018).

An oil palm agroforestry experiment was established in the lowland of Jambi, Sumatra, with the main goal of biodiversity enrichment by planting trees in oil palm plantations (Teuscher et al. 2016). The success of biodiversity enrichment will also partly depend on the landscape context. For example, remnants of secondary forest may act as source areas for certain taxa. On landscape scale, such potential source areas are distributed in varying distances to specific experimental plots, potentially having different influence on the biodiversity in particular plots. Moreover, the landscape configuration around the experimental area may also change over time and that also may induce temporal changes on biodiversity dynamics. The objectives of this study were to map the land use in the landscape surrounding this agroforestry experiment, and to analyze its shortterm changes.

\subsection{Methods}

\subsubsection{Study site}

We studied an area of 1121 ha (about $3.3 \mathrm{~km} \times 3.3 \mathrm{~km}$ ) containing the 56 plots of the agroforestry experiment EFForTS-BEE (Teuscher et al. 2016) in the center of the study area. The study area is located near Bungku village, Jambi, Indonesia (Appendix Figure 1 and 2). Total area of agroforestry plots is about 150 ha, which were established in the area of PT. Humusindo Makmur Sejati company (Teuscher et al. 2016). 


\subsubsection{Image acquisition}

The software APM Mission Planner (version 1.3.16) was used with Google Satellite Map interface to mission fixed-wing drone flights from the center of EFForTS-BEE $\left(01.95{ }^{\circ} \mathrm{S}\right.$ and $\left.103.25^{\circ} \mathrm{E}\right)$. The area of interest (AOI) was divided into five separate missions (Appendix Figure 2). The auto-flying waypoints were generated inside the AOI and the drone turning points were set outside AOI (Appendix Figure 2). In October 2015 and again in October 2016, the fixed-wing drone (Aero M, 3D Robotics, USA) and cameras (Canon PowerShot SX260 HS, Japan) were used for capturing aerial imagery in red, green, blue (RGB) and near infrared (NIR) spectrums. The drone automatically flew above $300 \mathrm{~m}$ a.s.l. with image overlap of 50\% sideward and 50\% forward, which were set by Naumann (2015). Due to limitation of payload space, flights with RGB and modified-NIR cameras were conducted separately, but with the same mission plan and around midday. All cameras took images every three seconds using the Canon Hack Development Kit setting (Mitchell 2013). After landing, the mission $\log$ files were downloaded and recorded in shape format with DNRGPS software (version 6.0.0.15).

\subsubsection{Image preparation}

All unfocussed images were removed as quality check. Although image acquisition in 2015 was carried out during a haze period, the conditions only present a small effect to NIR band (Sun et al. 2017). For this reason, we only performed dehazing for RGB images derived in 2015. The batch-processing in Dehaze function (Camera Raw tool) in Photoshop CC 2015 was used for haze removal (Weinmann and Lourekas, 2016). After that, all images in 2015 and 2016 were registered with their corresponding time stamps from mission shape files and exported as compatible-logs images with software ExifToolGUI (version 5.16).

\subsubsection{Seamless-orthorectified map generation}

The Agisoft Photoscan Professional (version 1.2.6) was used to generate orthophoto and geo-referencing. All images from each mission were processed following these steps; image alignment, building dense point clouds, generation of digital surface model, and orthomosaic generation. In each mission from 2016, four rectangular ground control points (GCPs) in size $1.5 \mathrm{~m}$ by $1.5 \mathrm{~m}$ were visually tracked and georeferenced. In five missions, the spatial accuracy was determined with twenty referencing GCPs that were recorded from Garmin GPSmap 62 (Garmin International, Inc., USA), more details in Appendix Table 1. We co-registered orthophotos (five missions of RGB and NIR bands) in 2016 by conducting georeferencing from the third mission, which yielded the lowest GCPs error (mean $=1.2 \mathrm{~m} \pm 0.3$ standard deviation, Appendix Table 1). Although GCPs were not established in 2015, we co-registered all orthophotos (RGB and NIR band) from 2015 with georeferenced orthophotos from 2016. We assume that all orthophotos have the same accuracy.

We performed color balancing by using the bundled adjustment approach and adaptive filter for orthophotos in 2015 and 2016. These steps enhance homogeneity and maintain 
original color bands of the orthophoto (Hruby et al. 2016). Moreover, the Dodging tools optimized pixels of neighboring scenes between two overlapping images and at specific areas, adjusting the contrast and brightness of RGB orthophotos. All processing steps were carried out using PCI Geomatica software (2017) with Automatic and Manual Mosaicking tools (PCI Geomatics Enterprises, Inc., 2017). Then seamless orthophotos from each year were composited into one raster with 4 bands (RGB+NIR) and exported in TIFF format $(0.1 \mathrm{~m}$ resolution).

\subsubsection{Land use type classification with supervised classification}

The supervised classification with the maximum likelihood classifier was used to classify land use types following the pixel-based approach in ArcGIS (version 10.4). Training polygons samples were collected based on identification of land use type after ground truthing. One hundred ground truths were conducted based on a filed based survey in 2015 using random sampling in area of approximately 624 ha. Additional information regarding the land use types nearby the ground truth points were also recorded. Both RGB and false-color composite bands (NIR, R and G) were visualized during training polygon creation with a minimum pixel level of 750 pixels per polygon (Noi and Kappas, 2018). Firstly, the seamless orthophoto (0.1 m resolution) in 2016 was classified by supervised classification in 7 land use classes: secondary forest, oil palm plantation, rubber plantation, other vegetation (bushes, grass and orchards), water, urban, and bare soil (see definition of 7 classes in Appendix Table 2). However, haze was not completely removed from the orthomosaic raster in 2015 (Appendix Figure 1b). In order to make the orthomosaic rasters from both years comparable, we generated two-additional training classes for 2015 by adding polygons of oil palm plantation and secondary forest covered by haze. After supervised classification, the two additional classes were reclassified into oil palm plantation and secondary forest. Following these steps, all classified maps in 2015 and 2016 contained 7 classes with $0.1 \mathrm{~m}$ of resolution (TIFF format).

\subsubsection{Post processing for land use maps (8 classes)}

Misclassified pixels and noise pose a great influence on land use change detection. After supervised classification with 7 classes, we applied post-processing steps to reduce misclassified classes and noise pixels in land use maps ( $0.1 \mathrm{~m}$ resolution). All small pixel groups, less than 5000 pixels, were optimized following these steps: majority filter, boundary clean, region group, set null and nibble (Mattupalli et al. 2018), with subsequent steps from 1000, 2000, 3000, 4000 to 5000 pixels. These post- processing steps were limited at 5000 pixels because portions of area classified as bare soil became invisible after these steps.

Supervised classification was not carried out for all classes in this study because the increasing number of classes may reduce the overall land use map accuracy (Ma et al. 2017). In addition, fallow may indicate to area that will change into oil palm plantation in the future (Wicke et al. 2008). We reclassified the misclassified land use types and separated other vegetation into fallow and orchard. As a result, land use maps contained 
8 classes of land use: secondary forest, oil palm plantation, rubber plantation, fallow, orchard, water, urban, and bare soil (see definition of 8 classes in Appendix Table 2). Finally, we decided to decrease map resolution to $10 \mathrm{~m}$ in order to remove small pixel groups from single objects, individual oil palms and trees. The 10-m resolution land use maps containing 8 classes for 2015 and 2016 were generated in TIFF format. All processing steps were done in the ArcGIS (version 10.4).

\subsubsection{Accuracy tests}

Accuracy assessment was tested with land use maps in 2015 and in 2016 (8 classes, 10$\mathrm{m}$ resolution) by creating reference points (total 504 points) using equalized-stratifiedrandom point sampling in ArcGIS (version 10.4). For each reference point, a certain land use type was extracted from the land use map as classification data. All reference points were manually defined based on land use type for each year by on-screen identification. Moreover, 100 ground-truth points in 2015 were displayed to crossreference the land use information to further support the identification of land use type. Finally, overall accuracy, user's accuracy, and producer's accuracy were calculated from the confusion matrix (Appendix Table 5-6).

\subsubsection{Land use change detection}

Polygons of all land use types between 2015 and 2016 were overlaid and intersected. The spatial data of each land use class such as intersect area and non-intersect area were exported in a pivot table to calculate transformation areas. A change detection map depicting land use transformation between 2015 and 2016 (Figure 4.1c) was created with ArcGIS (version 10.4) using the Intersect tool and pivot table analysis. 

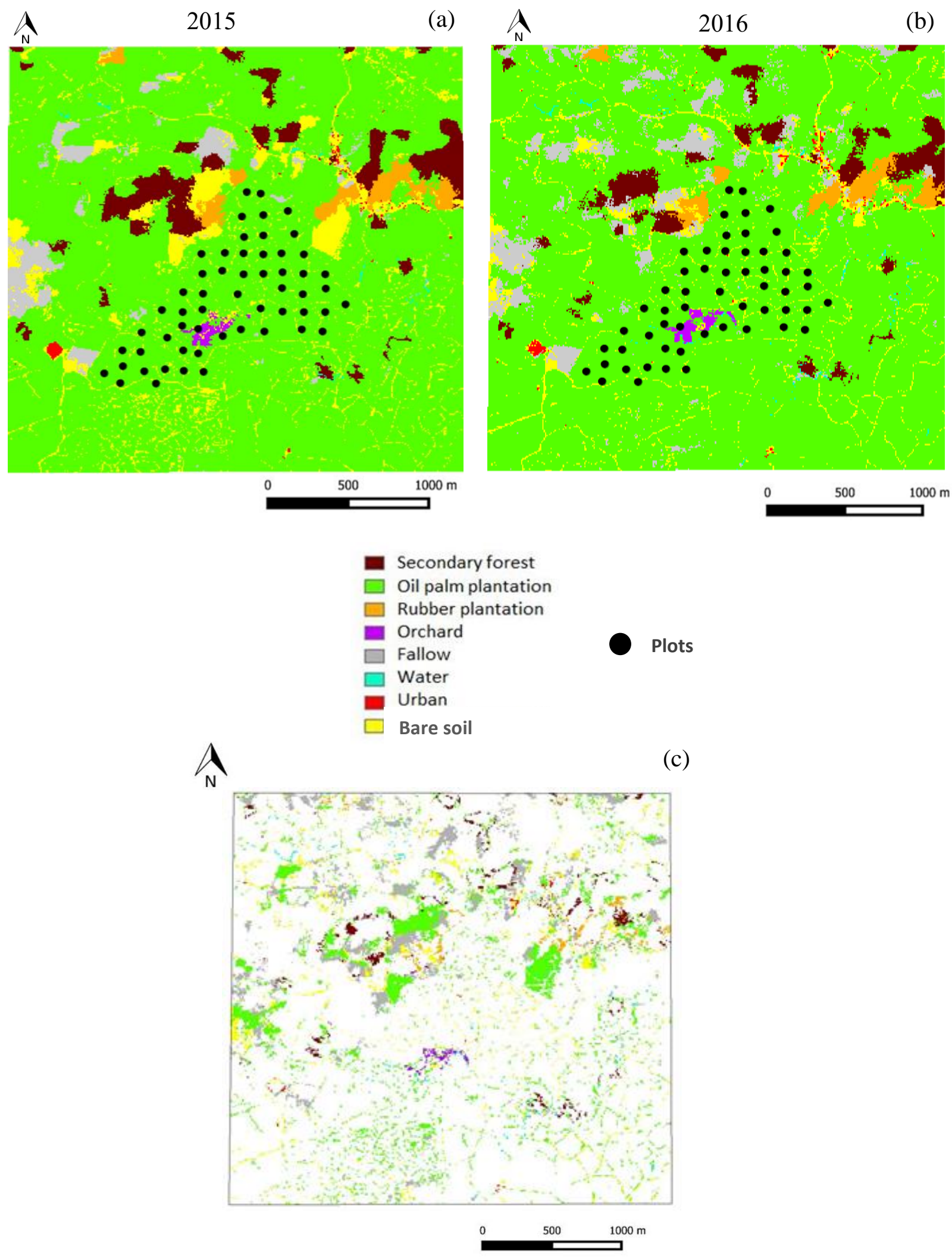

Figure 4.1. The land use maps in 2015 (a) and 2016 (b) with $10 \mathrm{~m}$ resolution are shown with the 8 land use types and marked agroforestry plots. Overall accuracy of land use map in 2015 and in 2016 was $84 \%$ and $82 \%$, respectively. The change detection map (c) depicts unchanged areas in white and changed land use areas in the color of the new classes. 


\subsubsection{Spatial pattern analysis by class and landscape indices}

Indices of eight land use types as "class indices" and landscape level as "landscape indices" were calculated in FRAGSTAT software (version 4.2.1) (McGarigal 2015). For the class indices, we mainly compared number of patches in percentage, mean patch area, edge density, and landscape shape index (see definitions in Appendix Table 4). To analyze landscape fragmentation we calculated: Euclidean nearest neighbor distance (ENN), clumpiness index, and landscape division index (DIVISION, Jaeger 2000) (see definitions in Appendix Table 4). For landscape indices, Shannon's diversity index and evenness, and Simpson's diversity index and evenness were computed (see definitions in Appendix Table 4).

Table 4.1. Transformation of land use types from 2015 to 2016 in the total area 1121 ha. In each class, percentages of area (\%) showed the proportion of the land use transformation in 2016 from the total class area in 2015. Bold values represent the stable area $(\%)$ without transformation to other classes.

\begin{tabular}{|c|c|c|c|c|c|c|c|c|c|c|}
\hline & \multirow{2}{*}{ Land use class } & \multicolumn{9}{|c|}{ Year 2016} \\
\hline & & $\begin{array}{c}\text { Secondary } \\
\text { forest }\end{array}$ & $\begin{array}{l}\text { Oil palm } \\
\text { plantation }\end{array}$ & $\begin{array}{c}\text { Rubber } \\
\text { plantation }\end{array}$ & Orchard & Fallow & Water & Urban & $\begin{array}{c}\text { Bare } \\
\text { soil }\end{array}$ & Total \\
\hline \multirow{8}{*}{ 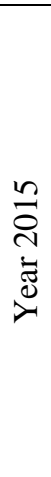 } & Secondary forest & 66 & 18 & 2 & 0 & 10 & 0 & 0 & 3 & 100 \\
\hline & Oil palm plantation & 1 & 94 & 0 & 0 & 2 & 0 & 0 & 2 & 100 \\
\hline & Rubber plantation & 2 & 15 & 76 & 0 & 3 & 0 & 0 & 4 & 100 \\
\hline & Orchard & 0 & 16 & 0 & 76 & 0 & 3 & 0 & 5 & 100 \\
\hline & Fallow & 1 & 27 & 0 & 0 & 62 & 0 & 0 & 9 & 100 \\
\hline & Water & 1 & 18 & 0 & 0 & 7 & 71 & 0 & 3 & 100 \\
\hline & Urban & 1 & 6 & 0 & 1 & 2 & 0 & 73 & 17 & 100 \\
\hline & Bare soil & 1 & 50 & 1 & 1 & 15 & 0 & 1 & 31 & 100 \\
\hline
\end{tabular}

\subsection{Results}

\subsubsection{Land use types and change detection}

The land use map area for both 2015 and 2016 was 1121 ha. In 2015, oil palm plantation covered $81 \%$ ( $907 \mathrm{ha}$ ) of the total area and the other classes covered about 19\% (Figure 4.2). Minority land uses in 2015 included bare soil (9\%), secondary forest (5\%), fallow (3\%), rubber plantations (2\%); and the smallest were orchard, water and urban, which covered less than 1\% (Figure 4.2). From 2015 to 2016, the analysis of land use change suggests that, of the total map area, the area of secondary forest decreased by $1 \%$ (10 ha), and bare soil decreased by 4\% (47 ha), whilst fallow increased by 3\% (29 ha, Figure 4.2 and 4.3). Areas of rubber plantation, orchard, water and urban did not change much within one year (Figure 4.3). From 2015 to 2016, the analysis of land use transformation 
showed that $18 \%$ of secondary forest area, $15 \%$ of rubber and $16 \%$ of orchard were converted to oil palm plantation (Table 4.1). Moreover, about half of bare soil (50\%) was transformed to new oil palm plantation (Table 4.1 and Appendix Table 3).
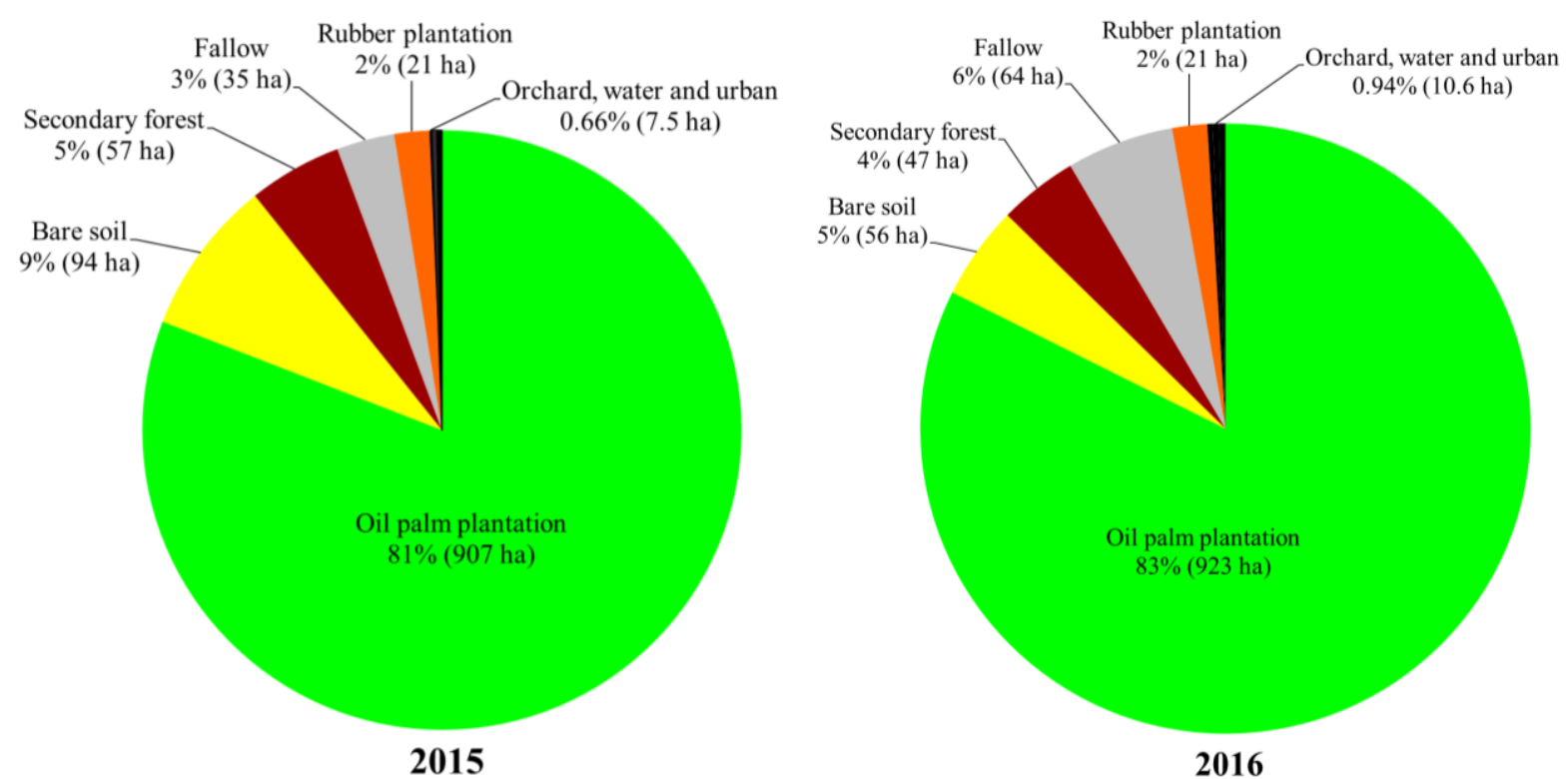

Figure 4.2. Percent coverage area (\%) and total area (ha) by land use types in 2015 and 2016 summarized for the entire total area of 1121 ha.

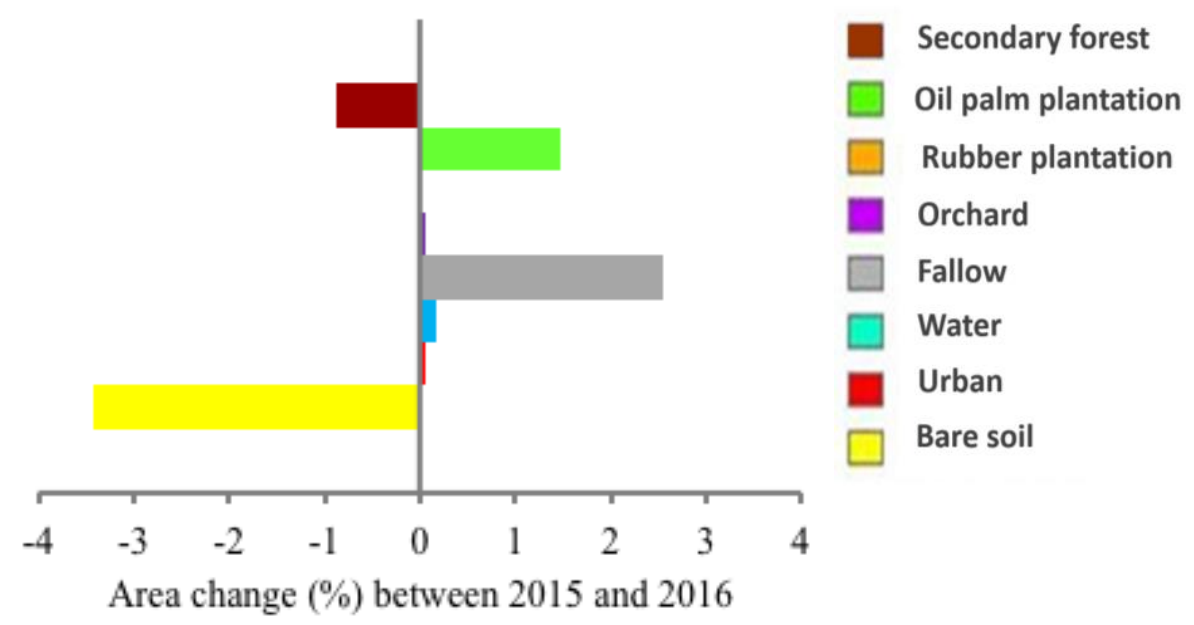

Figure 4.3. Area change (\%) of land use between 2015 and 2016 was estimated from initial area of land use type in 2015. 


\subsubsection{Landscape patterns}

All 8 classes from the final land use maps were in clumped pattern: clumpiness index's ranging from 0.3 (water) to 0.9 (secondary forest and rubber plantation) in 2015 (Table 4.2). Oil palm plantation likely formed in one patch (DIVISION in $2016=0.3$ and DIVISION in $2015=0.4$ ) with the largest mean patch area (Figure 4.4) and connected in short distance, indicating by low ENNs (Table 4.2). Whereas, other land use types were maximally subdivided (DIVISION=1.0, Table 4.2). Comparison between 2015 and 2016, secondary forest, oil palm plantation, rubber plantation and orchard had very few differences in percentage number of patches, mean patch area, edge density, and landscape shape index (Figure 4.4). Oil palm plantation showed the highest mean patch area compared to other land uses and the decrease of mean patch size was found in 2016 (Figure 4.4). Fallow presented the highest percentage number of patches, also an increase, and distinct change in edge density and landscape shape index (Figure 4.4). In contrast, percentage number of patches and edge density of bare soil decreased but change in their landscape shape index was very little (Figure 4.4). On the landscape level, all indices did not notably change within one year (Table 4.3).

Table 4.2. Class level indices explained spatial patterns of land use in the study area. Mean of Euclidean nearest neighbor distance (ENN), clumpiness index, and landscape division index (DIVISION) of land use types were compared between 2015 and 2016.

\begin{tabular}{lcccccc}
\hline & \multicolumn{3}{c}{ Year 2015 } & \multicolumn{3}{c}{ Year 2016 } \\
\cline { 2 - 7 } Land use types & ENN & $\begin{array}{c}\text { Clumpiness } \\
\text { index }\end{array}$ & DIVISION & $\begin{array}{c}\text { ENN } \\
(\mathrm{m})\end{array}$ & $\begin{array}{c}\text { Clumpiness } \\
\text { index }\end{array}$ & DIVISION \\
\hline Secondary forest & 73.4 & 0.9 & 1.0 & 38.9 & 0.8 & 1.0 \\
Oil palm plantation & 24.9 & 0.7 & 0.4 & 23.9 & 0.7 & 0.3 \\
Rubber plantation & 112.9 & 0.9 & 1.0 & 131.5 & 0.8 & 1.0 \\
Orchard & 25.9 & 0.8 & 1.0 & 22.1 & 0.8 & 1.0 \\
Fallow & 60.2 & 0.8 & 1.0 & 46.4 & 0.7 & 1.0 \\
Water & 75.0 & 0.3 & 1.0 & 61.5 & 0.3 & 1.0 \\
Urban & 103.2 & 0.5 & 1.0 & 97.3 & 0.4 & 1.0 \\
Bare soil & 28.1 & 0.5 & 1.0 & 31.3 & 0.4 & 1.0 \\
\hline
\end{tabular}


Table 4.3. Landscape level indices were analyzed in order to explain spatial pattern of landscape in 2015 and 2016.

\begin{tabular}{lcc}
\hline Landscape indices & Year 2015 & Year 2016 \\
\hline Shannon's diversity & 0.8 & 0.7 \\
Shannon's evenness & 0.4 & 0.4 \\
Simpson's diversity & 0.3 & 0.3 \\
Simpson's evenness & 0.4 & 0.4 \\
\hline
\end{tabular}

(a)

(b)
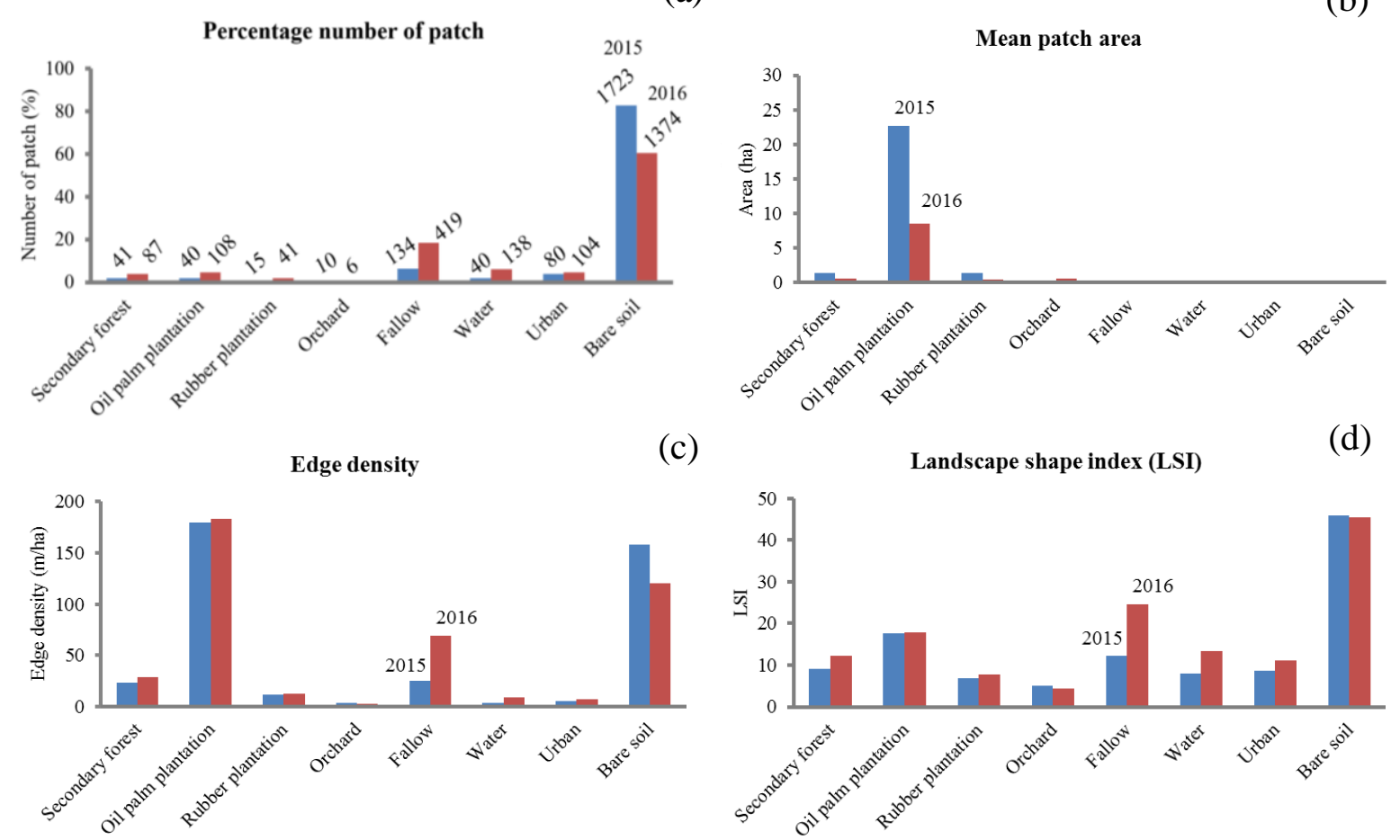

Figure 4.4. Comparison of four class level indices from land use types between 2015 and 2016; percentage number of patches (a); number of patches indicated above the bars of each land use type, mean area of patch (b), edge density (c) and landscape shape index (d). 


\subsection{Discussion}

This study conducted a drone-based assessment over a one year period for the propose of studying land use distribution, change of land use, and landscape patterns around oil palm agroforests and in oil palm dominated landscape. Some of the methodological developments discussed may benefit further works in drone-based imagery for landscape monitoring.

\subsubsection{Problems with drone-based data processing and method improvement}

The short flying distance of drones usually limit the coverage area of image acquisition (Puliti et al. 2015). Five of drone flight missions covered all areas of the total 1121 ha. However, light inconsistency from cloud shadow and different image acquisition time led to imbalanced colors within orthophotos. In this case, construction of high quality landscape maps typically requires seamless algorithms (Tian et al. 2016). We followed the methods of image brightness and saturation adjustment (Hruby et al. 2016) that could generate seamless orthophotos. There were some focal points that still required other more robust methods such as Wallis dodging and Gaussian distance weight enhancement (Tian et al. 2016). Furthermore, haze removal is required for the orthophoto in 2015 because there was haze covering Jambi from land-clearing fires. The effect of haze was reduced but not completely removed. Alternatively, by applying radiometric calibrations, it is possible to remove haze components (Gehrke and Beshah 2016; Bahari et al. 2018).

In the initial land use maps, using the pixel-based approach with supervised classification to generate high resolution of land use maps $(0.1 \mathrm{~m}$ resolution) was very challenging. The land use maps showed many misclassified pixels, small spots of noise and isolated pixels (salt and pepper effect), which could influence the overall accuracy of land use maps (Cui et al. 2018; Müllerová et al. 2017). In other cases, lower accuracy land use maps were generated when using high resolution images with supervised classification (Amalisana et al. 2017) and object-based classification ( $\mathrm{Lu}$ and $\mathrm{He}$, 2017). Importantly, post-processing steps were highly recommended (Lu and Weng 2007). In this way, methods from Mattupalli et al. (2018) could reduce small pixel groups from being misclassified and reclassification could correct the proper land use types based on user's visual interpretation. Alternatively, using supervised sub-pixel technique ( $\mathrm{Li}$ et al. 2014), unsupervised classification (Pradhan et al. 2014), texture analysis with image segmentation (Baudoin et al. 2017), and object-based analysis (Arif et al. 2017; Mafanya et al. 2017; Müllerová et al. 2017) may have enough capacity to generate a land use map from a high-resolution orthophoto. 


\subsubsection{Landscape change and patterns of land use transformation}

Previous land use maps derived from satellite imagery (Melati 2017), depicted oil palm plantation covering only $23 \%$ and $40 \%$ of this study area in 1990 and 2013, respectively. We used drone-derived land use maps $(10 \mathrm{~m})$ from 2015 to 2016 to determine land use change and area transformation. In 2016, oil palm plantation dominated $83 \%$ of the landscape area and this monoculture plantation increased in area by replacing secondary forest and bare soil areas. Additionally, we found that fallow areas were frequently transformed to oil palm plantation, and a small area of rubber plantation was also converted to oil palm plantation; however, the total area of rubber plantation remained stable. This detection of land use change, but stable total area for rubber plantation, may be attributed to the moderate accuracy (overall accuracy about $82 \%$ and $84 \%$ ) of the land use maps. These findings provide evidence that oil palm expanded into fallow and rubber plantation areas (Gatto 2015). On the other hand, local people might have an interest in maintaining rubber plantations because they offer an alternative income source during the low season of oil palm harvest (Meijaard and Sheil 2013) despite the fact that oil palm harvest takes place year round (Teuscher et al. 2016; Gérard et al. 2017). In our study area, we also found that orchard area remained in one area and experienced very little change to other land uses. We expect that the orchard area may fulfill local peoples' needs without expanding, similar to the rubber plantation area. In the case of water area, the small apparent increase in area between 2015 and 2016 might be due to the El Niño dry event in 2015 (Meijide et al. 2018).

Different land use types had varying patterns of change from 2015 to 2016. Compared with other land use types, fallow increased in percentage number of patches, edge density, and landscape shape index, while bare soil greatly decreased in percentage number of patches and edge density. Moreover, secondary forest, rubber plantation, orchard and fallow were more fragmented in a clumped distribution. While water, urban and bare soil were more disaggregated in a random distribution. Oil palm plantation showed a decreased mean patch area and distributed in a single patch while other land use types were totally fragmented. We assume that reduction of mean patch area of oil palm plantation is probably related to the moderate accuracy of the land use maps and the increase of the small patch areas of oil palm, transformed from other land use types. In comparison, Melati (2017) discovered slightly increasing mean patch area of oil palm plantation in Jambi province between 2000 and 2013. However, the scale of our study area is relatively too small to realistically compare to the macro scale of Jambi province.

\subsubsection{Implications for conservation}

In Jambi province, oil palm intensification and land use transformation were potentially linked to urban development (Feintrenie et al. 2010) and oil palm smallholders mainly focused on economic benefits from oil palm production rather than sustainable management (Wicke et al. 2008). Land use assessment clearly revealed the transformation of the high conservation value areas, such as secondary forests around agroforestry plots, which could be linked to oil palm expansion. In order to maintain forest areas in this landscape, we recommend presenting the current land use 
information to encourage public awareness and promote collaboration between local people and oil palm stakeholders.

Spatial information of the landscape surrounding the experimental plots can support other biodiversity studies. In other oil palm dominated landscapes, presence of intact forests affected diversity of birds (Bennett et al. 2018) and mammal species (Pardo et al. 2018). In our study site, patches of secondary forest, present near the northern experimental agroforestry plots, possibly containing certain tree species, may have also influenced biodiversity of these plots. In the future, biodiversity studies could benefit from the high accuracy maps generated from drone-based monitoring for conservation purposes, especially inside the oil palm agroforestry landscape.

\subsection{Conclusions}

Drone-based assessment for aerial image acquisition is relatively easy to conduct and repeat for temporal and long-term analysis. The land use maps demonstrate that the oil palm agroforestry experiment is located in a landscape largely dominated by oil palm monocultures. Within one year, oil palm cultivation increased in area at the expense of fallow, secondary forest, bare soil areas. 


\subsection{References (Chapter 4)}

Amalisana, B., Rokhmatullah, \& Hernina, R. 2017. Land cover analysis by using pixelbased and object-based image classification method in Bogor. In The 5th Geoinformation Science Symposium.

Arif, M. S. M., Gülch, E., Tuhtan, J. A., Thumser, P., \& Haas, C. 2017. An investigation of image processing techniques for substrate classification based on dominant grain size using RGB images from UAV. International Journal of Remote Sensing 38: 2639-2661.

Bahari, N. I. S., Ahmad, A., Aboobaider, B., Razali, M. F. B., Sakidin, H., Isa, M. S. M., Ananta, G. P., Sari, Y. A., \& Sari, N. A. 2018. Remote sensing data restoration to compensate for haze effect. Journal of Theoretical and Applied Information Technology 96 (1): 118-126.

Baudoin, A., Bosc, P. M., Bessou, C., \& Levang, P. 2017. Review of the diversity of oil palm system in Indonesia: case study of two provinces: Riau and Jambi. Center for International Forestry Research, Bogor, Indonesia.

Bennett, R., Leuenberger, W., Leja, B. B. B., Cáceres, A. S., Johnson, K. , \& Larkin, J. 2018. Conservation of Neotropical migratory birds in tropical hardwood and oil palm plantations. PLOS ONE 13(12).

Clough, Y., Krishna, V. V., Corre, M. D., Darras, K., Denmead, L. H., Meijide, A., Moser, S., ... Scheu, S. 2016. Land-use choices follow profitability at the expense of ecological functions in Indonesian smallholder landscapes. Nature Communications 7.

Cui, G., Lv, Z., Li, G., Benediktsson, J. A., \& Lu, Y. 2018. Refining land cover classification maps based on dual-adaptive majority voting strategy for very high resolution remote sensing images. Remote Sensing 10 (1238): 1-19.

Dislich, C., Keyel, A. C., Salecker, J., Kisel, Y., Meyer, K. M., Auliya, M., ... Faust, H. 2017. A review of the ecosystem functions in oil palm plantations, using forests as a reference system. Biological Reviews 92 (3): 1539-1569.

FAO. 2006. FAOSTAT online statistical service. Available at: http://faostat.fao.org (Accessed December 27, 2018).

FAO. 2016. FAOSTAT online statistical service. Available at: http://faostat.fao.org (Accessed May 31, 2018).

Feintrenie, L., Chong, W. K., \& Levang, P. 2010. Why Do Farmers Prefer Oil Palm? Lessons Learnt from Bungo District, Indonesia. Small-Scale Forestry 9 (3).

Frate, L., Saura, S., Minotti, M., Martino, P. D., Giancola, C., \& Carranza, M. L. 2014. Quantifying forest spatial pattern trends at multiple extents: an approach to detect significant changes at different scales. Remote Sensing 6 (10): 9298-9315.

Gatto, M. 2015. Land-use dynamics, economic development, and institutional change in rural communities - evidence from the Indonesian oil palm sector. $\mathrm{PhD}$ Dissertation. University of Goettingen, Goettingen, Germany. 
Gehrke, S., \& Beshah, B. 2016. Radiometric normalization of large airborne image data sets acquired by different sensor types. ISPRS - International Archives of the Photogrammetry, Remote Sensing and Spatial Information Sciences 41: 317-326.

Gérard, A., Wollni, M., Hölscher, D., Irawan, B., Sundawati, L., Teuscher, M., \& Kreft, H. 2017. Oil-palm yields in diversified plantations: initial results from a biodiversity enrichment experiment in Sumatra, Indonesia. Agriculture, Ecosystems and Environment 240: 253-260.

Hruby, F., Melamed, S., Ressl, R. \& Stanley, D. 2016. Mosaicking Mexico - the big picture of big data. ISPRS - International Archives of the Photogrammetry, Remote Sensing and Spatial Information Sciences 41: 407-412.

Iizuka, K., Itoh, M., Shiodera, S., Matsubara, T., Dohar, M., \& Watanabe, K. 2018. Advantages of unmanned aerial vehicle (UAV) photogrammetry for landscape analysis compared with satellite data: a case study of postmining sites in Indonesia. Cogent Geoscience 4 (1): 1-15.

Jaeger, J. A. G. 2000. Landscape division, splitting index, and effective mesh size: new measures of landscape fragmentation. Landscape Ecology 15 (2): 115-130.

Kalantar, B., Mansor, S. B., Sameen, M. I., Pradhan, B., \& Shafri, H. Z. M. 2017. Drone-based land-cover mapping using a fuzzy unordered rule induction algorithm integrated into object-based image analysis. International Journal of Remote Sensing 38: 2535-2556.

Koh, L. P., \& Wilcove, D. S. 2008. Is oil palm agriculture really destroying tropical biodiversity?. Conservation Letters 1 (2): 60-64.

Li, M., Zang, S., Zhang, B., Li, S., \& Wu, C. 2014. A review of remote sensing image classification techniques: the role of spatio-contextual information. European Journal of Remote Sensing 47 (1): 389-411.

Lu, B., \& He, Y. 2017. Optimal spatial resolution of unmanned aerial vehicle (UAV)acquired imagery for species classification in a heterogeneous grassland ecosystem. GIScience and Remote Sensing 55 (2).

Lu, D., \& Weng, Q. 2007. A survey of image classification methods and techniques for improving classification performance. International Journal of Remote Sensing 28 (5): 823-870.

Ma, L., Li, M., Ma, X., Cheng, L., Du, P., \& Liu, Y. 2017. A review of supervised object-based land-cover image classification. ISPRS Journal of Photogrammetry and Remote Sensing 130: 277-293.

Mafanya, M., Tsele, P., Botai, J., Manyama, P., Swart, B., \& Monate, T. 2017. Evaluating pixel and object based image classification techniques for mapping plant invasions from UAV derived aerial imagery: Harrisia Pomanensis as a case study. ISPRS Journal of Photogrammetry and Remote Sensing 129: 1-11.

Mattupalli, C., Moffet, C. A., Shah, K. N., \& Young, C. A. 2018. Supervised classification of RGB aerial imagery to evaluate the impact of a root rot disease. Remote Sensing 10 (917).

McGarigal, K. 2015. "Fragstats help: spatial pattern analysis program for categorical and continuous Maps." University of Massachusetts, Amherst. 
Meijaard, E., \& Sheil, D. 2013. Oil-palm plantations in the context of biodiversity conservation. Encyclopedia of Biodiversity 5.

Meijide, A., Shekhar C., Moyano F., Tiralla, N., Gunawan, D., \& Knohl, A. 2018. Agricultural and forest meteorology impact of forest conversion to oil palm and rubber plantations on microclimate and the role of the 2015 ENSO event. Agricultural and Forest Meteorology 252: 208-219.

Melati, D. 2017. The use of remote sensing data to monitor land use systems and forest variables of the tropical rainforest landscape under transformation in Jambi Province, Sumatra, Indonesia. PhD Dissertation. University of Goettingen, Goettingen, Germany.

Mitchell, D. 2013. Zenoshrdlu: simple tool for installing CHDK. Available at: www.zenoshrdlu.com (Accessed August 24, 2013).

Müllerová, J., Brůna, J., Bartaloš, T., Dvořák, P., Vítková, M., \& Pyšek, P. 2017. Timing is important: unmanned aircraft vs. satellite Imagery in plant invasion monitoring. Frontiers in Plant Science 8: 1-13.

Naumann, R. V. 2015. Exploration of tropical landscape structures by an unmanned aerial vehicle in Sumatra. Master Thesis. University of Goettingen, Goettingen, Germany.

Noi, P. T., \& Kappas, M. 2018. Comparison of random forest, k-nearest neighbor, and support vector machine classifiers for land cover classification using Sentinel-2 imagery. Sensors 18 (1).

Pádua, L., Vanko, J., Hruška, J., Adão, T., Sousa, J. J., Peres, E., \& Morais, R. 2017. UAS, sensors, and data processing in agroforestry: a review towards practical applications. International Journal of Remote Sensing 38: 2349-2391.

PCI Geomatics Enterprises, Inc. 2017. Geomatica orthoengine course exercises. Available at: https://www.pcigeomatics.com/pdf/TrainingGuide-GeomaticaOrthoEngine.pdf (Accessed August 31, 2018).

Pardo, L. E., Campbell, M. J., Edwards, W., Clements, G. R. \& Laurance, W. F. 2018. Terrestrial mammal responses to oil palm dominated landscapes in Colombia. PLoS ONE 13(5).

Pradhan, B., Hagemann, U., Shafapour, M., \& Prechtel, N. 2014. An easy to use ArcMap based texture analysis program for extraction of flooded areas from TerraSAR-X satellite Image. Computers and Geosciences 63: 34-43.

Puliti, S., Ørka, H. O., Gobakken, T., \& Næsset, E. 2015. Inventory of small forest areas using an unmanned aerial system. Remote Sensing 7: 9632-9654.

Sayer, J., Ghazoul, J., Nelson, P., \& Boedhihartono, A. K. 2012. Oil palm expansion transforms tropical landscapes and livelihoods. Global Food Security 1 (2): 114119.

Sun, L., Latifovic, R., \& Pouliot, D. 2017. Haze removal based on a fully automated and improved haze optimized transformation for Landsat imagery over land. Remote Sensing 9 (972).

Teuscher, M., Gérard, A., Brose, U., Buchori, D., Clough, Y., Ehbrecht, M., ... Kreft, H. 2016. Experimental biodiversity enrichment in oil-palm-dominated landscapes in Indonesia. Frontiers in Plant Science 7. 
Tian, J., Li, X., Duan, F., Wang, J., \& Ou, Y. 2016. An efficient seam elimination method for UAV images based on Wallis dodging and Gaussian distance weight enhancement. Sensors 16 (5).

Weinmann, E., \& Lourekas, P. 2016. Visual quickstart guide Photoshop CC (2015 release). Peachpit Press, the United States of America.

Wicke, B., Sikkema, R., Dornburg, V., \& Faaij, A. 2011. Exploring land use changes and the role of palm oil production in Indonesia and Malaysia. Land Use Policy 28 (1): 193-206.

Wicke, B., Sikkema, R., Wicke, B., Dornburg, V., Junginger, M., \& Faaij, A. 2008. Drivers of land use change and the role of palm oil production in Indonesia and Malaysia: overview of past developments and future projections. Copernicus Institute for Sustainable Development and Innovation, Utrecht University 


\subsection{Appendix (Chapter 4)}

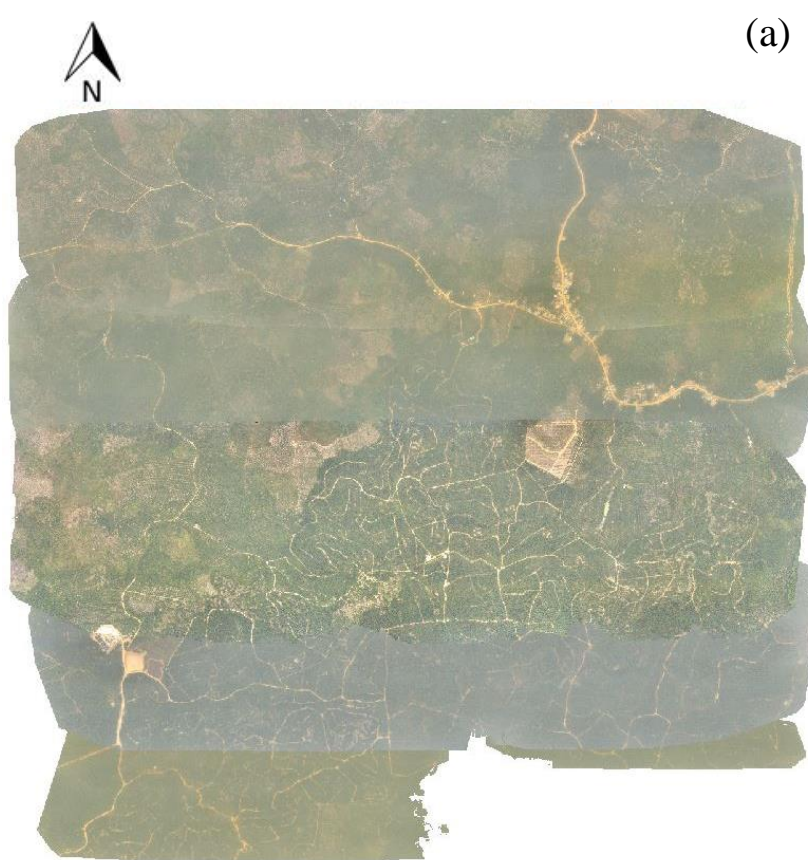

A

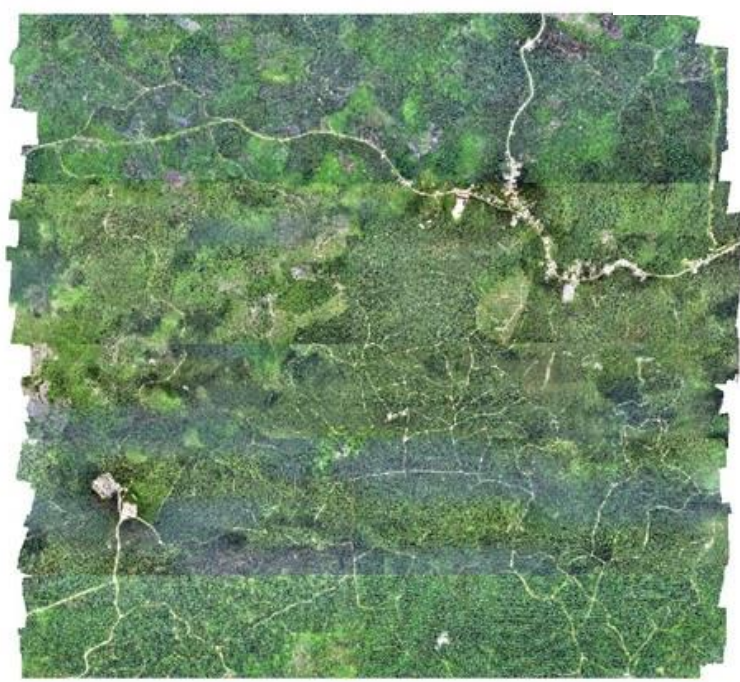

(a) (b)

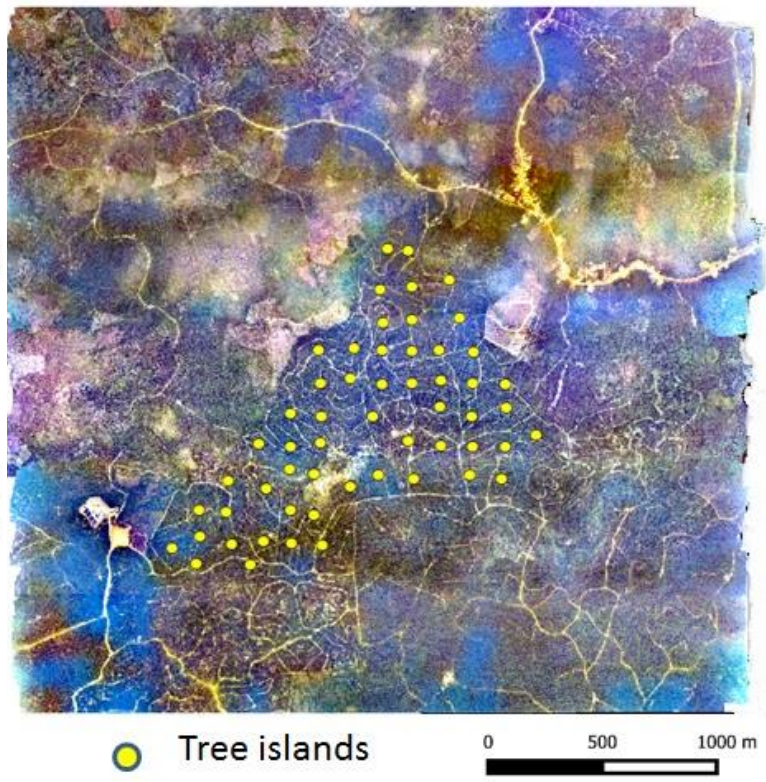

(d)

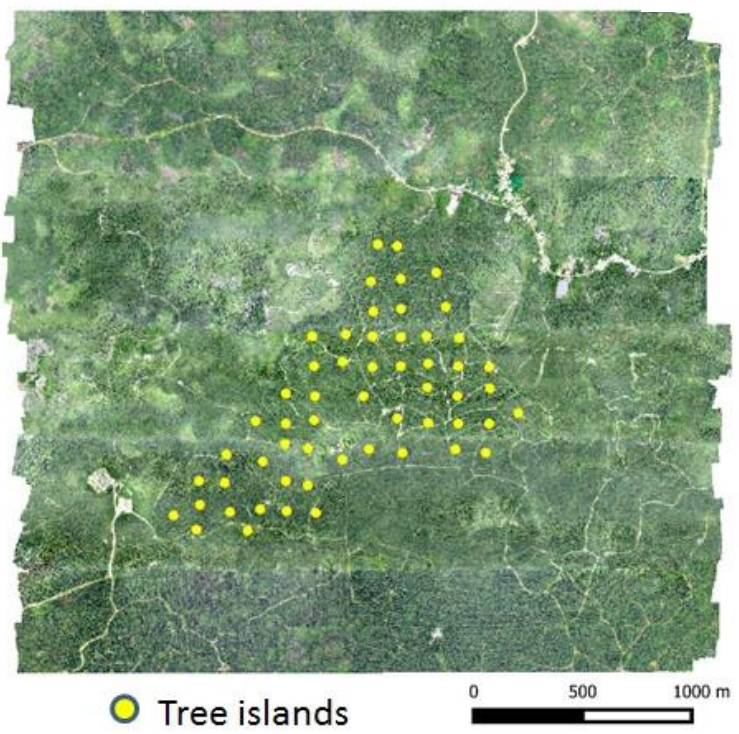

Appendix Figure 1. RGB map in 2015 without haze removal (a), RGB seamless orthophoto in 2015 applied haze removal (b), original RGB map in 2016 (c) and RGB seamless orthophoto in 2016 (c). Locations of tree islands in agroforestry experiment (EFForTS-BEE) are showed (b, d). 


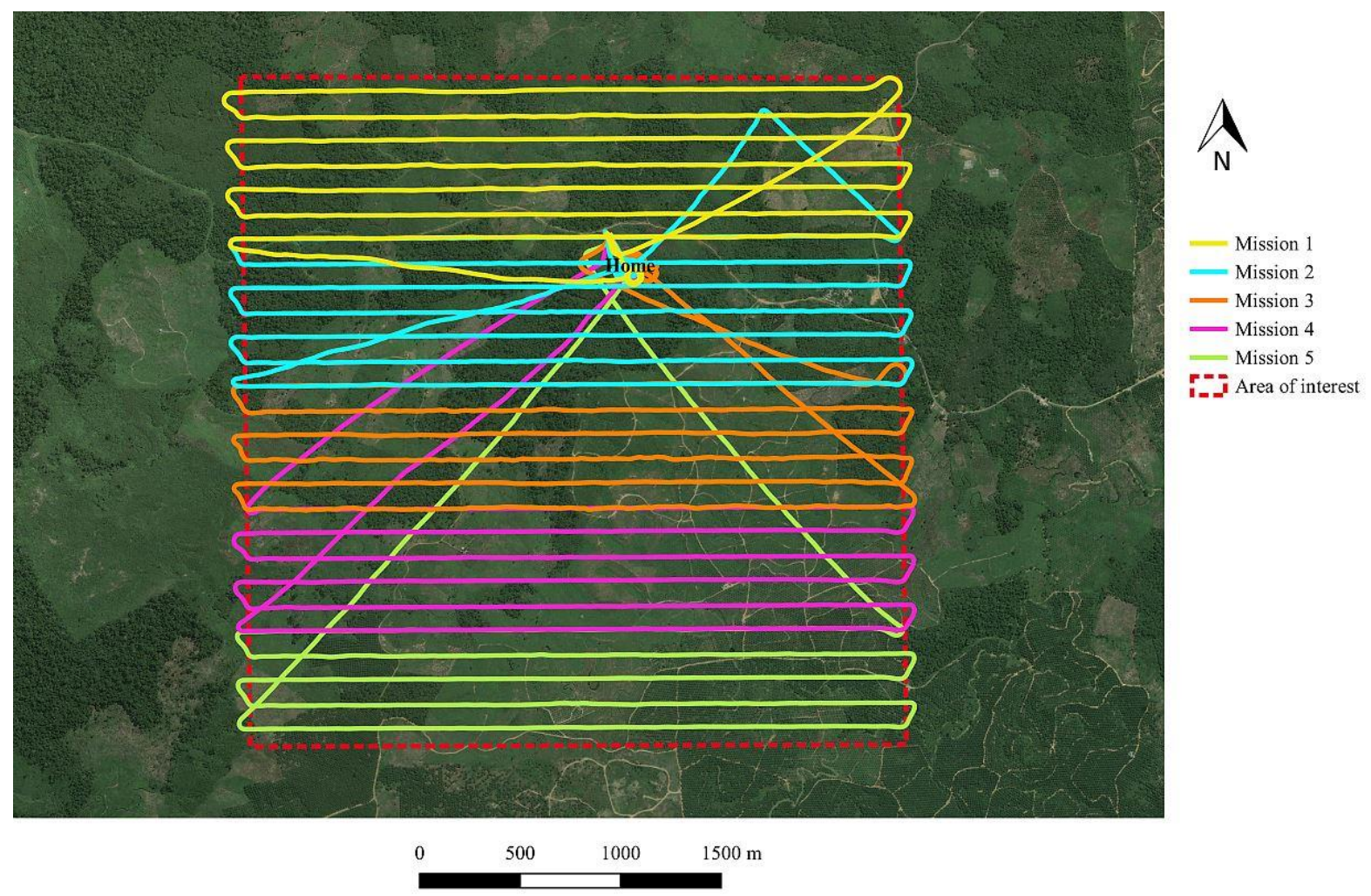

Appendix Figure 2. Overview flight plan divided into 5 missions for aerial imagery acquisition in the area of interest about 1100 ha. 
Appendix Table 1. Spatial accuracy measured in error (m) from ground control points (GCPs) from the RGB mission 2016 and mission 3 was used for co-registration with other orthomosic maps in 2015 and 2016.

\begin{tabular}{|c|c|c|c|c|c|c|c|c|}
\hline Mission & $\begin{array}{c}\text { GCP } \\
\text { number }\end{array}$ & Longitude & Latitude & $\begin{array}{l}\text { Altitude } \\
\quad(\mathrm{m})\end{array}$ & $\begin{array}{l}\text { X error } \\
(\mathrm{m})\end{array}$ & $\begin{array}{c}\text { Y error } \\
\text { (m) }\end{array}$ & $\begin{array}{c}\text { Z error } \\
\text { (m) }\end{array}$ & $\begin{array}{l}\text { Total } \\
\text { error } \\
\text { (m) }\end{array}$ \\
\hline 1 & 1 & 103.249663 & -1.936042 & 59.42 & 0.92 & -2.26 & -0.78 & 2.56 \\
\hline 1 & 2 & 103.244566 & -1.935497 & 58.66 & -0.51 & -0.01 & 1.18 & 1.29 \\
\hline 1 & 3 & 103.240963 & -1.934016 & 59.76 & 0.21 & 1.22 & -0.30 & 1.28 \\
\hline 1 & 4 & 103.259398 & -1.931341 & 51.19 & -1.00 & 1.21 & -0.54 & 1.67 \\
\hline 2 & 5 & 103.247429 & -1.938993 & 67.47 & 3.72 & -0.68 & -1.58 & 4.10 \\
\hline 2 & 6 & 103.258504 & -1.939779 & 53.00 & 0.11 & 5.64 & -1.37 & 5.80 \\
\hline 2 & 7 & 103.260404 & -1.942976 & 52.53 & 1.62 & -4.56 & -0.66 & 4.89 \\
\hline 2 & 8 & 103.254118 & -1.940232 & 42.58 & -5.85 & -0.61 & 4.77 & 7.57 \\
\hline 3 & 9 & 103.256134 & -1.946491 & 49.28 & -0.33 & 0.36 & -0.54 & 0.73 \\
\hline 3 & 10 & 103.251293 & -1.945966 & 63.39 & 0.33 & -1.15 & 0.24 & 1.22 \\
\hline 3 & 11 & 103.253197 & -1.950383 & 44.66 & 1.09 & 0.51 & 0.74 & 1.41 \\
\hline 3 & 12 & 103.247863 & -1.951263 & 46.47 & -1.40 & 0.56 & -0.12 & 1.51 \\
\hline 4 & 13 & 103.240795 & -1.954103 & 52.30 & -1.72 & -1.50 & -0.12 & 2.28 \\
\hline 4 & 14 & 103.244304 & -1.955141 & 43.25 & 2.01 & 2.36 & -0.09 & 3.10 \\
\hline 4 & 15 & 103.250580 & -1.955235 & 48.26 & 0.02 & -0.60 & 0.15 & 0.62 \\
\hline 4 & 16 & 103.259020 & -1.952972 & 36.78 & -0.32 & -0.29 & -0.10 & 0.44 \\
\hline 5 & 17 & 103.240112 & -1.958876 & 59.84 & -0.02 & -0.80 & -0.91 & 1.21 \\
\hline 5 & 18 & 103.244396 & -1.960172 & 56.04 & 2.11 & 0.04 & -0.05 & 2.11 \\
\hline 5 & 19 & 103.251285 & -1.958364 & 53.35 & -3.70 & 2.10 & 1.42 & 4.49 \\
\hline 5 & 20 & 103.260004 & -1.957801 & 60.57 & 1.66 & -1.30 & -0.81 & 2.26 \\
\hline
\end{tabular}


Appendix Table 2. Definition of classes observed from ground based survey for classification with drone data and visualization.

\begin{tabular}{|c|c|c|}
\hline $\begin{array}{l}\text { Major class } \\
\text { (supervised classification) }\end{array}$ & $\begin{array}{c}\text { Subclass } \\
\text { (manual reclassification) }\end{array}$ & Definition \\
\hline Secondary forest & - & $\begin{array}{l}\text { Patches of forest and disturbed } \\
\text { forest, which are bigger than } 0.5 \text { ha } \\
\text { (FAO 2006). From the prior } \\
\text { classification maps in 2013, forest } \\
\text { area in Bungku village and study site } \\
\text { were indicated as the secondary } \\
\text { forest (Melati 2017) }\end{array}$ \\
\hline Oil palm plantation & - & $\begin{array}{l}\text { Cultivated area for palm-oil } \\
\text { agriculture. Young oil palms were } \\
\text { defined as oil palm plantation that } \\
\text { should have canopy size at least } 1 \mathrm{~m} \\
\text { in the same homogeneous filed. }\end{array}$ \\
\hline Rubber plantation & - & $\begin{array}{l}\text { The agricultural land use for planting } \\
\text { rubbers and partial mixed with tree } \\
\text { species. Some other tree species' } \\
\text { canopy could be seen where rubbers' } \\
\text { canopy are dominant. }\end{array}$ \\
\hline \multirow[b]{2}{*}{ Other vegetation } & Orchard & Rambutan plantation \\
\hline & Fallow & $\begin{array}{l}\text { Predominant grasses or shrubs where } \\
\text { natural vegetation growth may take } \\
\text { place after disturbance (Wicke et al. } \\
\text { 2008). }\end{array}$ \\
\hline Water & - & $\begin{array}{l}\text { Stream, canal and non-flowing water } \\
\text { as lake. }\end{array}$ \\
\hline Urban & - & $\begin{array}{l}\text { Area of intensive houses in village. } \\
\text { Individual household structures. The } \\
\text { residential area and construction site } \\
\text { are included in this class. }\end{array}$ \\
\hline Bare soil & - & $\begin{array}{l}\text { Barren soil without tree cover or } \\
\text { pathway for transportation. }\end{array}$ \\
\hline
\end{tabular}


Appendix Table 3. The transformation matrix of land use change in the total area of 1121 ha. The land use class area (ha) in 2015 was compared with the status in 2016. Bold values represent the stable area (ha).

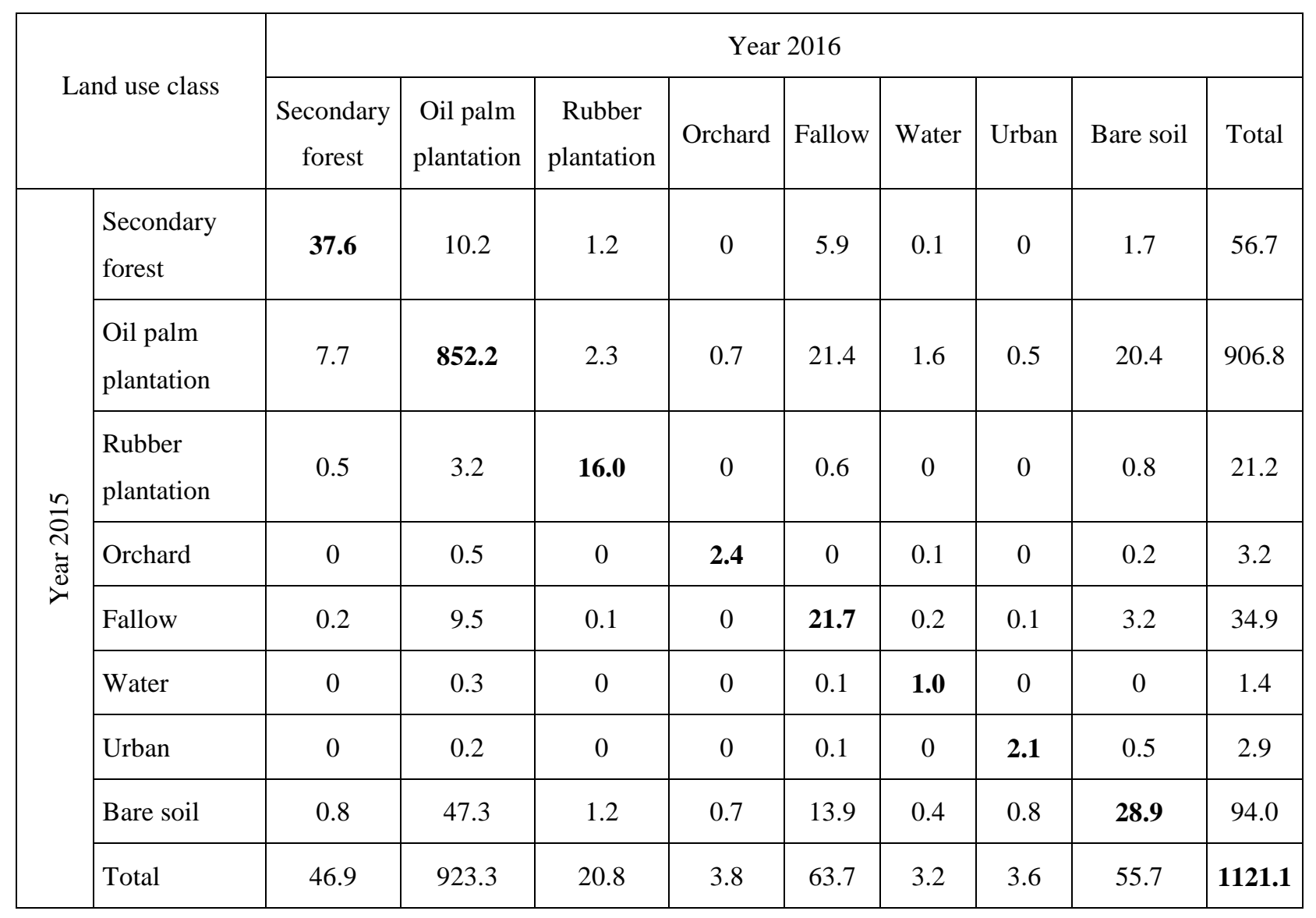


Appendix Table 4. Details of landscape indices for landscape level and class (patch) level and descriptions (Jaeger 2000; McGarigal 2015; Frate et al. 2014).

\begin{tabular}{|c|c|c|c|}
\hline Indices & Level & Unit & Description \\
\hline $\begin{array}{l}\text { Euclidean nearest } \\
\text { neighbor distance } \\
(\mathrm{ENN})\end{array}$ & Class & $\mathrm{m}$ & $\begin{array}{l}\text { The distance from a patch to the } \\
\text { nearest neighboring patch of the } \\
\text { same land use type. }\end{array}$ \\
\hline Clumpiness index & Class & $\begin{array}{l}\text { None } \\
\text { Range; } \\
-1<\text { CLUMPY <1 }\end{array}$ & $\begin{array}{l}\text { Index equals }-1 \text { when the patch type } \\
\text { is maximally disaggregated, equals } 0 \\
\text { when the focal patch type is } \\
\text { distributed randomly, and equals } 1 \\
\text { when the patch type is maximally } \\
\text { clumped. }\end{array}$ \\
\hline $\begin{array}{l}\text { Landscape division } \\
\text { index (DIVISION) }\end{array}$ & Class & $\begin{array}{l}\text { None } \\
\text { Range; } \\
0<\text { DIVISION <1 }\end{array}$ & $\begin{array}{l}\text { Probability that two randomly } \\
\text { chosen places in the landscape are } \\
\text { not situated in the same area } \\
\text { DIVISION = 0, when the landscape } \\
\text { consists of single patch. DIVISION = } \\
1 \text {, when the landscape is maximally } \\
\text { subdivided. }\end{array}$ \\
\hline Number of patch & Class & Number $(\mathrm{N})$ & $\begin{array}{l}\text { Number of patches at the class or } \\
\text { landscape level. }\end{array}$ \\
\hline Mean patch area & Class & ha & $\begin{array}{l}\text { The average area of patches } \\
\text { comprising a landscape mosaic. }\end{array}$ \\
\hline Edge density & Class & $\mathrm{m} / \mathrm{ha}$ & $\begin{array}{l}\text { The total length of all class edges per } \\
\text { area. }\end{array}$ \\
\hline $\begin{array}{l}\text { Landscape shape } \\
\text { index }\end{array}$ & Class & $\begin{array}{l}\text { None } \\
\text { Range; } \\
1 \geq \text { without limit }\end{array}$ & $\begin{array}{l}\text { A standardized measure of total edge } \\
\text { or edge density that adjusts for the } \\
\text { size of the landscape. Index was } \\
\text { calculated from } 0.25 \text { times of total } \\
\text { edge length divided total landscape } \\
\text { area. Landscape shape index equal } 1 \\
\text { when the landscape consists of a } \\
\text { single square patch. }\end{array}$ \\
\hline $\begin{array}{l}\text { Shannon's diversity } \\
\text { index }\end{array}$ & Landscape & $\begin{array}{l}\text { None } \\
0 \geq \text { without limit }\end{array}$ & $\begin{array}{l}\text { Increasing as the number of different } \\
\text { patch types increases and/or the } \\
\text { proportional distribution of area } \\
\text { among patch types becomes more } \\
\text { equitable. Index equals } 0 \text { when the } \\
\text { landscape contains only } 1 \text { patch or no } \\
\text { diversity. }\end{array}$ \\
\hline
\end{tabular}


Appendix Table 4. (Cont.) Details of landscape indices for landscape level and class (patch) level and descriptions (Jaeger 2000; McGarigal 2015; Frate et al. 2014).

\begin{tabular}{|l|l|l|l|}
\hline Indices & \multicolumn{1}{|c|}{ Level } & \multicolumn{1}{|c|}{ Unit } & \multicolumn{1}{c|}{ Description } \\
\hline $\begin{array}{l}\text { Shannon's evenness } \\
\text { index }\end{array}$ & Landscape & $\begin{array}{l}\text { None } \\
0 \leq \text { index } \leq 1\end{array}$ & $\begin{array}{l}\text { Index equals 0 when the landscape } \\
\text { contains only 1 patch (no diversity). } \\
\text { Index equals 1 when an even } \\
\text { distribution of area among patch } \\
\text { types results in maximum evenness. }\end{array}$ \\
\hline $\begin{array}{l}\text { Simpson's diversity } \\
\text { index }\end{array}$ & Landscape & $\begin{array}{l}\text { None } \\
0 \leq \text { index } \leq 1\end{array}$ & $\begin{array}{l}\text { Simpson's index is less sensitive to } \\
\text { the presence of rare types than } \\
\text { Shannon's index. Index equals 0 } \\
\text { when the landscape contains only 1 } \\
\text { patch (no diversity). Index equals 1 } \\
\text { when the number of different patch } \\
\text { (richness) increases and the } \\
\text { proportional distribution of area } \\
\text { among patch types become more } \\
\text { equitable. }\end{array}$ \\
\hline $\begin{array}{l}\text { Simpson's evenness } \\
\text { index }\end{array}$ & Landscape & None \\
$0 \leq$ index $\leq 1$ & $\begin{array}{l}\text { An even distribution of area among } \\
\text { patch types results in maximum } \\
\text { evenness. Index equals 0 when the } \\
\text { landscape contains only 1 patch (no } \\
\text { diversity). Index equals 1 when } \\
\text { distribution of area among patch } \\
\text { types is perfectly even or } \\
\text { proportional abundances are the } \\
\text { same. }\end{array}$ \\
\hline
\end{tabular}


Appendix Table 5. Map accuracy assessment performing in confusion matrix table of land use map in 2015, which has overall accuracy $84 \%$.

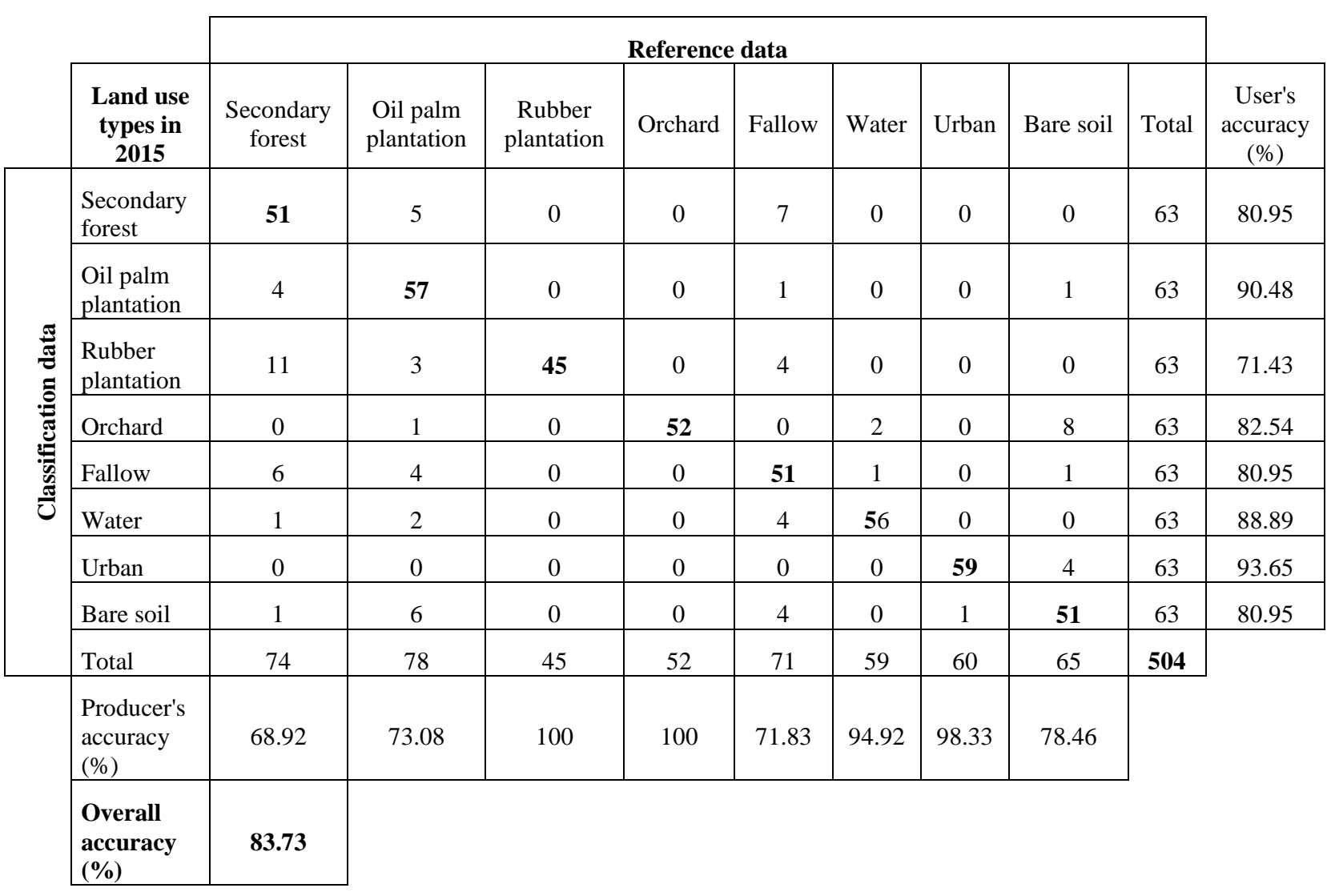


Appendix Table 6. Map accuracy assessment performing in confusion matrix table of land use map in 2016, which has overall accuracy $82 \%$.

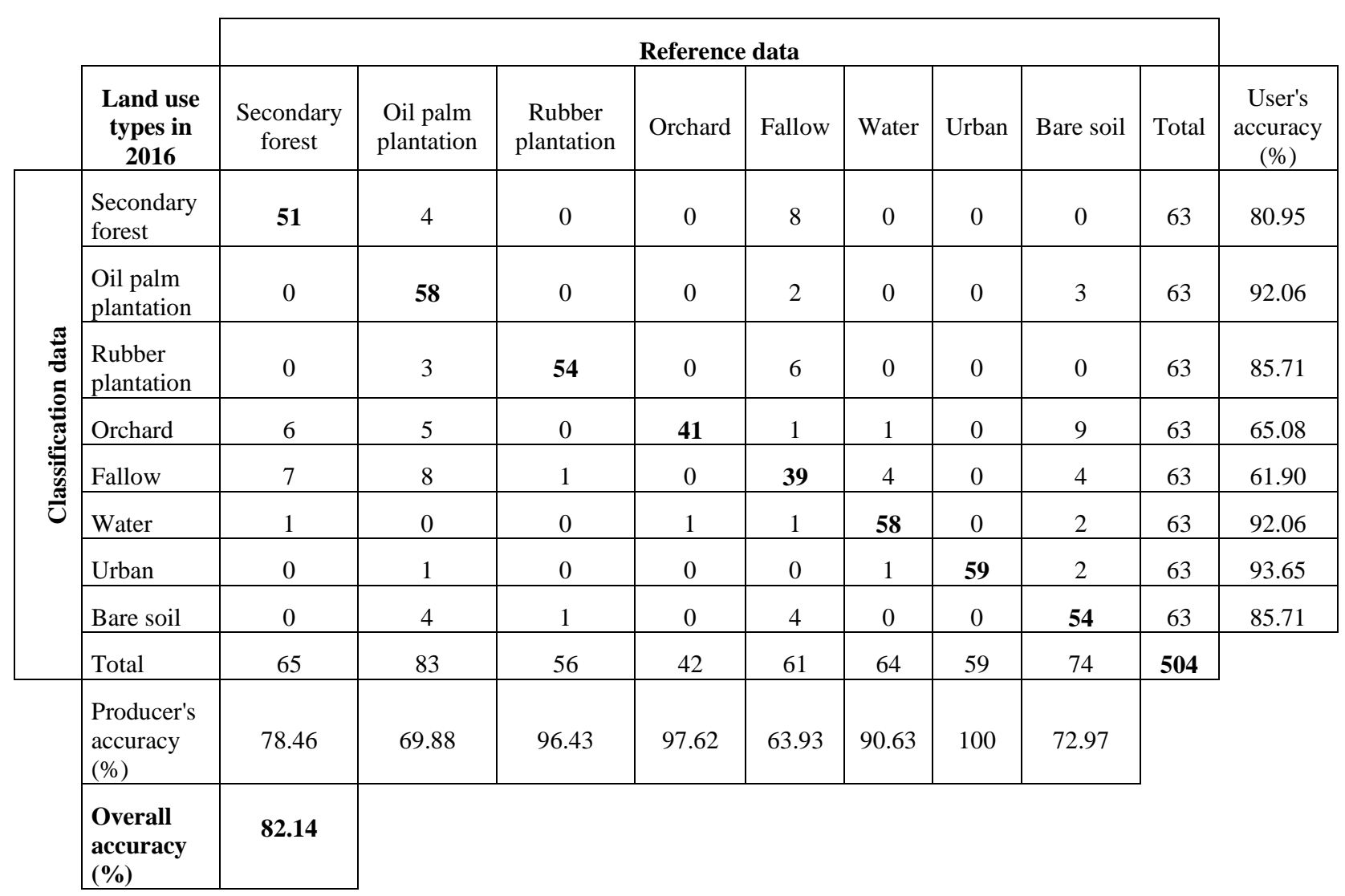




\section{Chapter 5}

\section{Synthesis}

The use of dense photogrammetric point clouds and high resolution of orthophotos affirmed the advantages of drone-assisted remotes sensing for ecological and landscape studies in the oil palm agroforest and the extensive oil palm landscape. The estimations of crown metrics and oil palm canopy cover from the low flying octocopter were very successful in predicting tree and oil palm water use and transpiration. Additionally, these estimations helped describe the influence of oil palm shading conditions on the mortality of three interplanted tree species in an oil palm agroforestry experiment. Moreover, the imagery obtained from the fixed-wing drone could be used to produce a landscape map, classify land use, and analyze patterns of land use change. Overall, this study can share the benefits and conclusions of using drones in these research fields, and also provide suggestions for methodological improvements that could be developed in the future.

\subsection{Usefulness of drone-based data for crown metrics and canopy cover analyses}

The mission design of the low flying drone is a crucial step in acquiring fine resolution orthophotos and high density SfM point clouds (Chapter 2 and 3). The quality of SfM point clouds is affected by the design of camera angles (nadir and oblique) and high proportion of image overlapping (Vacca et al. 2017). Additionally, both orthophotos and SfM point clouds were generated from image acquisition in grid and circular patterns (Chapter 2 and 3). Consequently, the RGB orthophotos had a very fine resolution, and the SfM point clouds were very dense, presenting clear details of tree and oil palm crowns in 3D (Chapter 2 and 3). The drone-based point clouds showed high capacity in the measurement of crown metrics and were comparable to groundbased crown measurements (Chapter 2). Similarly, the drone-derived canopy cover had high correlation with the estimates from hemispherical photography (Chapter 3).

The drone-derived CHM and RGB orthophoto were very useful for tree and oil palm height estimation (Chapter 2), canopy partitioning (Chapter 3), and comparing canopy cover with hemispherical photograph estimates (Chapter 3). Nevertheless, the crown segmentation with CHM could not always partition oil palm canopies from tree canopies (Chapter 3). To overcome this limitation, fine resolution of RGB orthophotos and delineated crown polygons were used for the manual selection of oil palm canopy from other clumped canopies (Chapter 3). As in the equation of respective buffer sizes to compare canopy cover measured from drone with such estimates from hemisphere photographs (equation 2 in Chapter 3), average height of vegetation from CHM was used to calculated buffer area at the plot center. Moreover, coordinates of planted trees and high resolution RGB orthophotos were used to locate invisible trees (Chapter 3). However, some steps also required manual operation through on-screen visualization. 
All in all, every main step to derive crown metrics and canopy cover required a high quality of RGB orthophotos, SfM point clouds, and CHM.

\subsection{Success of using drone-based variables in oil palm agroforestry experiments}

Drone-derived crown volumes presented the best fitting variable related to sap flux measurement, enabling prediction of tree and oil palm water use (Chapter 2). Compared to the variable of stem diameter, tree crown volumes derived from drone-based imagery reduced the uncertainty of estimated transpiration (Chapter 2). For oil palms, uncertainty of drone-based approach was higher than ground-based method (Chapter 2). Therefore, drone-based application offered a new and promising measurement method in plant water use analysis, from individual plants to the stand level of transpiration.

The effect of oil palm thinning inside agroforest plots could be evaluated from the oil palm canopy cover distribution estimated from low altitude drone flights over both thinned and non-thinned plots (Chapter 3). Since the oil palm thinning at the onset of the agroforestry experiment, more open oil palm canopy conditions were sustained compared to non-thinned plots (Chapter 3). In order to enhance provision of ecosystem services from oil palm agroforests, management oil palm density through thinning may benefit mixed-species tree planting. This study found that more open oil palm shading environments reduced mortality rates of light demanding trees (A. pauciflorum and $S$. leprosula), and dense oil palm shadings reduced mortality rates of a shade tolerant species (D. zibethinus) (Chapter 3). As a result, the drone-based canopy cover analysis can be a useful approach for matching planted tree species in varying oil palm shade conditions.

\subsection{Landscape context analysis with spatial data from fixed-wing drone}

Since the oil-palm agroforest (EFForTS-BEE) was established in 2013 (Teuscher et al. 2016) the previous land use map from satellite imagery was compiled in that same year (Melati 2017), but the land use maps generated in 2015 and 2016 are the most updated spatial maps in the study area (Chapter 4). Land use maps from these two years informatively explain the rate of land use change and land use pattern transformation (Chapter 4). For example, areas of bare soil and fallow represented a transitional area to new oil palm cultivation (Chapter 4). Additionally, secondary forest decreased and mainly transformed to oil palm plantation and fallow (Chapter 4). The utilization of aerial imagery from fixed-wing drone surveys and spatial analyses demonstrate the expansion of oil palm cultivation, and highlight recent land use transformations in the area. Considering current land use policy regarding oil palm management, land use maps present clear landscape features that can assist data interpretation and groundbased investigations. 


\subsection{Disadvantage of fixed-wing drone and limitation of methods}

I attribute the success of low flying octocopter drone for crown metric and canopy cover measurements to the fine resolution orthophotos and high density of point clouds it obtained (Chapter 2 and 3). Due to 300-m flight altitude of fixed-wing drone, the grid pattern included 50\% image overlap in only the nadir direction (Chapter 4). Orthophotos from the fixed-wing drone have a coarser resolution $(0.1 \mathrm{~m})$ than the octocopter $(0.05 \mathrm{~m})$ and some parts are blurred. Theoretically, low altitude flight mission plans may be helpful to compensate for these problems, but this requires more flying time to cover the entire area (Puliti et al. 2015). Besides, image acquisition from fixed-wing drone was performed during the vast haze phenomenon in Sumatra in 2015 (Chapter 4). Although fixed-wing drone missions could be performed in the severe haze conditions, it was mandatory to improve map quality by haze removal and seamless orthomosaic methods (Chapter 4). Still, I found that the haze could not be completely removed (Chapter 4). Moreover, the RGB orthophotos showed inconsistency of light conditions, possibly from cloud shadows (Chapter 4). After running the supervised classification for the land use map, post-processing (reduction of misclassified classes from small pixel groups) and manual reclassification were necessary (Chapter 4). The poor results from the supervised classification might be partly explained by insufficient spectral bands in orthophotos, high numbers of land use classes, using fine resolution images, and low performance of the pixel-based approach. Hence, these are the limitations and weak points of the fixed-wing drone given the methods I implemented.

\subsection{Future outlook}

Crown metric estimates from SfM point clouds may be informative for tree and oil palm productivity in these types of agroforestry systems. Particularly for biomass, this variable is understudied with respect to crown volume. A previous study used height estimates from different digital terrain models (Kachamba et al. 2016) and tree crown metrics (e.g. crown height and crown width) from LiDAR point clouds (Jaafar et al. 2018 ) to estimate biomass in a forest. In oil palm agroforests, crown volume, or other crown metrics, may have potential to address this type of prediction, but several variables in such model equations need to be established. However, in dense agroforestry stands, it might be difficult to derive crown metrics of understory trees because drone-based photography could not detect trees under neighboring canopies. In the context of dense stands, terrestrial laser scanners possess a higher capability to capture data in the lower canopy and ground areas, providing detailed LiDAR point clouds (Rosca et al. 2018). SfM point clouds and terrestrial-LiDAR point clouds can be co-registered in order to estimate canopy structures in dense and heterogeneous forest stands (Kallimani 2016). In this way, a combination of these datasets will be one of the integrative measures that would possess the capacity for biomass prediction.

The canopy of planted tree species may be different in shape and size, and partitioned tree canopy cover can differ among tree species. The influence that canopy cover of 
neighboring trees has on planted tree performance still needs to be evaluated. Currently, the segmented tree canopy cover (Chapter 3 ) is ready to use for this analysis.

Furthermore, the drone-based assessment can be conducted in multi-year plan for monitoring tree height. I would recommend using drone data for tree height monitoring, which could be estimated from SfM point clouds (Trochta et al. 2017). Alternatively, CHM from drone-based method is highly possible for tree height estimation in the forest stands (Ota et al. 2017). However, the presence of ground vegetation may affect height estimations of trees, indicating from the ground surface. Since the last weeding in EFForTS-BEE stopped in 2015 (Teuscher et al. 2016), the ground areas may be invisible, possibly leading to inaccurate tree height measurement from drone surveys. I suggest measuring tree height through drone assessment in moderate and open canopy conditions, where plots present clear details of terrain area.

To improve the pixel-based classification approach, hyperspectral cameras and other image classifiers could be alternatively implemented ( $\mathrm{Lu}$ and Weng 2007). For supervised classification, I suggest using a coarser resolution for orthophotos, such as 5-10 m resolution, instead of $0.1 \mathrm{~m}$ resolution (Chapter 4). This might reduce smallisolated, and misclassified classes, and may not require post-processing steps.

Recently, assessments of animal and plant biodiversity in EFForTS-BEE were conducted. It is possible to observe species and community distributions inside experimental plots then compare these taxonomic data with the nearest secondary forest and other land use types. Relationships drawn from these comparisons could produce a spatial proximity link of biodiversity variation between the oil palm agroforest and the surrounding landscape. Drones could be suitable tools for routine monitoring and I recommend using drone-based imagery to produce a current land use map in 2019 for comparison to previous land use maps. Moreover, assessing trees outside forests at this scale is possible and high-resolution drone images can be used for this purpose. These data comparisons from the last four years would be valuable for landscape analysis regarding the increasing trend of oil palm cultivation. 


\subsection{Reference (Chapter 5)}

Jaafar, W. M. W. S., Woodhouse, I. H., Silva, C. A., Omar, H., Nizam, K., Maulud, A., \& Hudak, A. T. 2018. Improving individual tree crown delineation and attributes estimation of tropical forests using airborne LiDAR data. Forests 9 (759).

Kachamba, D. J., Ørka, H. O., Gobakken, T., Eid, T. \& Mwase, W. 2016. Biomass estimation using 3D data from unmanned aerial vehicle imagery in a tropical woodland. Remote Sensing 8 (11).

Kallimani, C. 2016. Tree crown shape parameter extraction from airborne photogrammetric point cloud. Master Thesis. Wageningen University and Research Centre.

Lu, D., \& Weng, Q. 2007. A survey of image classification methods and techniques for improving classification performance. International Journal of Remote Sensing 28 (5): 823-870.

Melati, D. 2017. The use of remote sensing data to monitor land use systems and forest variables of the tropical rainforest landscape under transformation in Jambi Province, Sumatra, Indonesia. PhD Dissertation. University of Goettingen, Goettingen, Germany.

Ota, T., Ogawa, M., Mizoue, N., Fukumoto, K., \& Yoshida, S. 2017. Forest structure estimation from a UAV-based photogrammetric point cloud in managed temperate coniferous forests. Forests 8 (9).

Puliti, S., Ørka, H. O., Gobakken, T., \& Næsset, E. 2015. Inventory of small forest areas using an unmanned aerial system. Remote Sensing 7: 9632-9654.

Ros ca, S., Suomalainen, J., Bartholomeus, H., \& Herold, M. 2018. Comparing terrestrial laser scanning and unmanned aerial vehicle structure from motion to assess top of canopy structure in tropical forests. Interface Focus 8.

Teuscher, M., Gérard, A., Brose, U., Buchori, D., Clough, Y., Ehbrecht, M., ... Kreft, H. 2016. Experimental biodiversity enrichment in oil-palm-dominated landscapes in Indonesia. Frontiers in Plant Science 7.

Trochta, J., Kruček, M., Vrška, T., \& Kraâl, K. 2017. 3D Forest: an application for descriptions of three-dimensional forest structures using terrestrial LiDAR. PLoS ONE 12 (5).

Vacca, G., Dessì, A., \& Sacco, A. 2017. The use of nadir and oblique UAV images for building knowledge. ISPRS International Journal of Geo-Information 6 (393). 


\section{Index of figures}

Figure 2.1 Aerial view of a studied oil palm agroforestry plot. Three years prior to the study, the stand was thinned with reduction in oil palm stems by $40 \%$, and six tree species were planted.

Figure 2.2 Canopy of an oil palm and a tree (Shorea leprosula) using point clouds from the drone missions and convex hull and alpha shape algorithms. Other tree species are shown in Appendix Figure 2.

Figure 2.3 Daily water use of oil palms (a) and trees (b) versus crown volumes. Note the different crown volume models and scales.

Figure 3.1 Overview of the biodiversity enrichment experiment (EFForTS-BEE) experimental plot number 23 (6 planted tree species, $40 \mathrm{~m}$ x $40 \mathrm{~m}$ ): (a) RGB orthophoto map (5 $\mathrm{mm}$ pixel-size) overlaid by oil palm canopy segmentations and referenced oil palm. The plot center is shown, where the ground-based hemispherical photograph was taken. (b) Oil palm canopy cover at 1-m resolution; higher values indicate more close canopy, while lower values indicate more open canopy, and (c) extraction of oil palm canopy cover at single tree level with buffers ( 2 m diameter).

Figure 3.2 Drone-derived canopy cover compared to ground-based hemispherical photography at plot center $(\mathrm{N}=56$ plots $)$ with a correlation coefficient $(\mathrm{R})=0.94$, RMSE $=$ $10.83 \%$. The equality line (black dashed line) indicates $1: 1$ relationship with $\mathrm{R}^{2}=0.84, p<0.01$.

Figure 3.3 Distribution of oil palm canopy cover in thinned and non-thinned plots where trees were planted $(\mathrm{N}$ thinned $=$ 24870 pixels and $\mathrm{N}_{\text {non-thinned }}=307$ pixels, in 48 plots). 
Figure 3.4 Tree mortality $\left(\% \mathrm{yr}^{-1}\right)$ between January 2016 and January 2017 within oil palm canopy cover. '*' indicates tree species with proportions of trees that died and survived between 2016 and 2017 dependent on oil palm canopy cover class (two-tailed $p<0.05$, Fisher's Exact test). The number of trees that died (N_dead) and survived (N_alive) are indicated above the bars (N_dead:N_alive) and the letters represent differences among oil palm canopy cover classes $(p<0.05$, pairwise test of independence). The total number of living trees in 2016 and number of dead trees in 2017 were 3819 and 507 , respectively.

Figure 4.1 The land use maps in 2015 (a) and 2016 (b) with $10 \mathrm{~m}$ resolution are shown with respective land use classes and agroforestry plots. Overall accuracy of land use map in 2015 and in 2016 was $84 \%$ and $82 \%$, respectively. The change detection map (c) depicts unchanged areas in white and changed land use areas in the color of the new classes.

Figure 4.2 Percent coverage area (\%) and total area (ha) by land use types in 2015 and 2016 summarized for the entire total area of 1121 ha.

Figure 4.3 Area change (\%) of land use between 2015 and 2016 was estimated from initial land use area in 2015.

Figure 4.4 Comparison of four class level indices from land use types between 2015 and 2016; percentage number of patch (a) indicating number of patch above the bars of each land use type, mean area of patch (b), edge density (c) and landscape shape index (d). 


\section{Index of tables}

Page

Table 2.1 Linear regressions between daily water use $\left(\mathrm{kg} \mathrm{day}^{-1}\right)$ and different aerial and ground based variables of oil palms $(n=8)$ and trees $(n=15)$. Only those linear regression which satisfy normality and homoscedasticity conditions are presented.

Table 2.2 Transpiration of the oil palm agroforest and monoculture plot with uncertainties for the scaling from individual plants to the plot level by bootstrapping linear relationships. For uncertainty estimates from ground-based scaling in oil palm we used an approach by Niu et al. (2015), which is based on the number of leaves that measurements were performed on and the resulting cumulative coefficient of variation (marked with an $*$ ).

Table 3.1 Planted tree species and some main ecological characteristics and purpose of uses.

Table 4.1 Transformation of land use types from 2015 to 2016 in the total area $1121 \mathrm{ha}$. In each class, percentages of area (\%) showed the proportion of the land use transformation in 2016 from the total class area in 2015. Bold values represent the stable area (\%) without transformation to other classes.

Table 4.2 Class level indices explained spatial patterns of land use in the study area. Mean of Euclidean nearest neighbor distance (ENN), clumpiness index, and landscape division index (DIVISION) of land use types were compared between 2015 and 2016.

Table 4.3 Landscape level indices were analyzed in order to explain spatial pattern of landscape in 2015 and 2016. 


\section{Acknowledgements}

First and foremost, I would like to thank my supervisor, Prof. Dr. Dirk Hölscher, for the inspirations, helpful comments and valuable suggestions through my research works. I want to give special thanks to Prof. Dr. Holger Kreft and Delphine Clara Zemp for helpful suggestions and the correction of manuscripts. Moreover, I would like to thank Prof. Dr. Christian Ammer for agreeing to be part of the examination committee.

I would like to thank Robin Victor Naumann, who created a nice work on drones that inspired me. I also express my thanks to David Dellatore, Graham Usher and Florian Ellsäßer for teaching me how to fly drones, plan flight missions and fix technical problems.

I thank Eva Siegelkow, secretary of my department, on administrative sections. A particular thanks is given to Edward Olson for his English corrections. I also thank Benjamin Wagner, Joshua André Erkelenz and Zulfi Kamal for all the support during the field trips in Jambi, Indonesia. I am thankful to all members in Tropical Silviculture and Forest Ecology department and all former colleagues.

I would like to acknowledge the German Research Foundation (DFG) in the framework of the Collaborative Research Centre 990 for research funding and providing assistances. I am thankful to the Development and Promotion of Science and Technology Talents Project (DPST) from Royal Government of Thailand for their help with living costs during the period of my $\mathrm{Ph}$. D. study in Germany.

I want to express my gratefulness to my parents and my brother in Thailand. I would like to express my appreciation of the friends I made during my 4-year stay in Germany (Preecha Kiatkirakajorn, Weeradej Khonsuntia, Tharaphat Ruamsukkunlasak, Matthias Frank Treutner and Volker Hoffmann), and other friendly Thai students in Göttingen, Hannover and Köln (Tammarat Piansawan), Germany. 


\section{Declaration of honor}

I hereby declare that I am the sole author of this dissertation entitled "DRONE-BASED ASSESSMENTS OF CROWNS, CANOPY COVER AND LAND USE TYPES IN AND AROUND AN OIL PALM AGROFORESTRY EXPERIMENT". All the references and data sources that were used in this dissertation have been acknowledged. I further declare that this work has never been submitted in any forms as part of any other dissertation procedure.

Goettingen, March 2019

(Watit Khokthong) 


\section{Curriculum vitae}

\section{Personal details}

Full name

Date of Birth

Watit Khokthong

Nationality

19 June 1988

Thai

\section{Education}

Ph. D. student in Forest Sciences and

Forest Ecology (2015-2019)

Master of Science in Biology (2014)

Bachelor of Science in Biology (2010)

Certificate of High School (2006)

\section{Research Experiences}

Associated Researcher (2015-2019)

Research Student (2013)

Research Student (2012)
Tropical Silviculture and Forest Ecology, University of Goettingen

Chiang Mai University, Chiang Mai, Thailand

Chiang Mai University, Chiang Mai, Thailand

Yupparaj Withayalai School, Chiang Mai, Thailand

Project Group B - Biota and ecosystem services (B11) in Collaborative Research Center 990 (CRC 990 EFForTS, University of Goettingen)

Advisor: Prof. Dr. Paulo Jose do Amaral Sobral, Faculty of Animal Science and Food Engineering, University of Sao Paulo, Brazil

The Siam Cement Public Company Limited, Lampang, Thailand

\section{Skills of Scientific Research and Analysis}

GIS Software (QGIS, ArcGIS, LiDAR360, LAStools, FUSION, FRAGSTATS)

Photogrammetric software (Agisoft Photoscan, Pix4D)

$\mathrm{R}$ programming language (3D analyses with GIS data, statistical analysis) 